\title{
WestVirginiaUniversity
}

THE RESEARCH REPOSITORY @ WVU

Graduate Theses, Dissertations, and Problem Reports

2007

\section{Modeling sediment movement in forested watersheds using hill- slope attributes}

\author{
Gregory W. Hamons \\ West Virginia University
}

Follow this and additional works at: https://researchrepository.wvu.edu/etd

\section{Recommended Citation}

Hamons, Gregory W., "Modeling sediment movement in forested watersheds using hill-slope attributes" (2007). Graduate Theses, Dissertations, and Problem Reports. 1871.

https://researchrepository.wvu.edu/etd/1871

This Thesis is protected by copyright and/or related rights. It has been brought to you by the The Research Repository @ WVU with permission from the rights-holder(s). You are free to use this Thesis in any way that is permitted by the copyright and related rights legislation that applies to your use. For other uses you must obtain permission from the rights-holder(s) directly, unless additional rights are indicated by a Creative Commons license in the record and/ or on the work itself. This Thesis has been accepted for inclusion in WVU Graduate Theses, Dissertations, and Problem Reports collection by an authorized administrator of The Research Repository @ WVU. For more information, please contact researchrepository@mail.wvu.edu. 


\title{
MODELING SEDIMENT MOVEMENT IN FORESTED WATERSHEDS USING HILL-SLOPE ATTRIBUTES
}

\author{
By
}

\section{Gregory W. Hamons}

\author{
Thesis submitted to the Davis College of Agriculture, Forestry, and Consumer \\ Sciences \\ at West Virginia University \\ in partial fulfillment of the requirements \\ for the degree of

\section{Master of Science \\ in Forestry}

\author{
Approved by \\ Dr. Jingxin Wang, Committee Chairperson \\ Dr. Pamela Edwards \\ Dr. Michael Strager \\ Dr. Joseph McNeel
}

Wood Science and Technology

Morgantown, West Virginia

2007

Keywords: Sediment Delivery, Spatial Modeling, Hill-Slope Attributes, Soil Erosion, Harvesting, Road Construction, and Appalachian Hardwood Forest 


\section{Abstract \\ Modeling Sediment Movement in Forested Watersheds Using Hill-slope Attributes}

The amount of sediment delivered to stream channels and the determination of the topographical attributes responsible for the origination and transfer of sediment were investigated in a central Appalachian mixed hardwood forest from 2002 through 2005. Two study watersheds were chosen within the Indian Run watershed in north central West Virginia. One remained undisturbed (control) and the other underwent road construction and tree harvesting operations (treatment). Sediment samples were collected from silt fences which were installed along both sides of the stream channels in both watersheds to ensure all sediment material delivered from adjacent hill-slopes was captured and collected. Sediment samples were collected annually, and analyses were performed on pre-road/harvest and post-road/harvest samples for the treatment watershed. The same sample collection and analysis procedures were performed for the control watershed as well. Visual, physical, and spatial observations were made before, during, and after road construction within the treatment watershed. Data were analyzed both spatially and statistically to determine the magnitude of effects from the topographical attributes, the road construction, and the harvesting operations on sediment delivery to the stream channel. The spatial and statistical analyses indicated an increase in sediment material production as a result of road construction within the treatment watershed as the annual sediment material collected increased some 1.7 times the year after the road construction procedure. On average the treatment watershed produced 7.2 times as much sediment material per-acre as did the control watershed over the study period. The variables in the treatment watershed that explained a significant $(\alpha=0.10)$ amount of sediment delivery were year, distance to tree falls (rootwads), distance to water driven erosion features (WDEFs), distance to naturally bare soil, and the distance to animal trails. Significant variables for the control watershed were year, contributing slope from each topographical feature, distance to naturally bare soil, bare soil area, and the distance to animal trails. Additionally, soil loss equations, specifically the Revised Universal Soil Loss Equation (RUSLE), were tested to compare modeled results to field measured results under these mountainous conditions. The soil loss equations had poor accuracy, yielding predictions many times larger than the actual masses of collected data. 


\section{Dedication}

The author wishes to dedicate this project to his parents, Joe and Rose Hamons, and his family, without their love, help, and support this would have never happened. The author would also like to dedicate this project to Dwan Bolyard for all of her love and support. I love you all. 


\section{Acknowledgments}

The author would like to thank Dr. Jingxin Wang for providing this opportunity and lending his help throughout. Special thanks go to Dr. Pam Edwards and Ms. Frederica Wood with the USDA Forest Service for initiating this project and lending their time and suggestions throughout. The authors would also like to thank the late Dr. George Seidel for helping with statistical analysis and Mr. Tony Goff for help throughout. Additionally the author thanks Dr. Michael Strager and Dr. Joe McNeel for serving on the committee and their help throughout the project. The author wishes to thank the USDA Forest Service for funding this project and the staff at the Parsons, West Virginia headquarters for help with data collection and sample processing, particularly Greg Evans. The author is also grateful to the other staff and professionals of the USDA Forest Service, Monongahela National Forest for their cooperation and facilitation for the completion of this project. In addition the author thanks all the professors, staff, and friends at the West Virginia University Division of Forestry and Natural Resources. 
TABLE OF CONTENTS

ABSTRACT ……...........................................................................................................................................................i

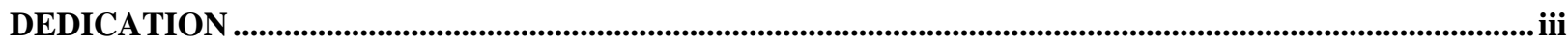

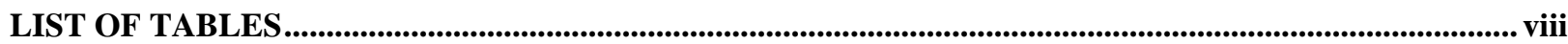

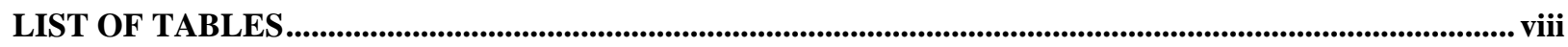

INTRODUCTION

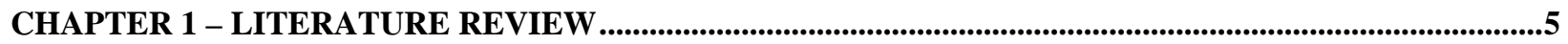

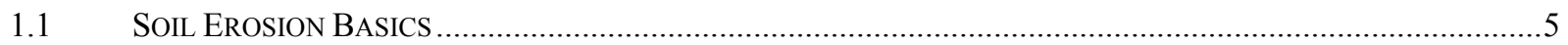

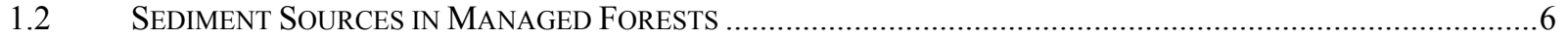

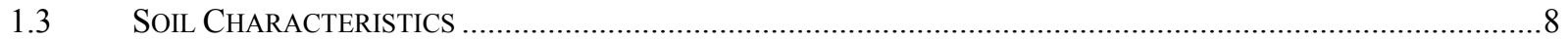

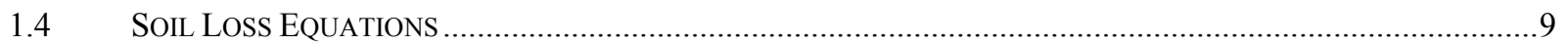

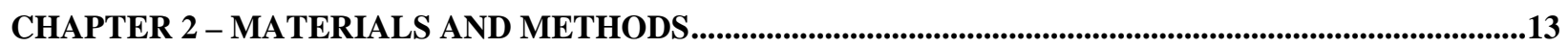

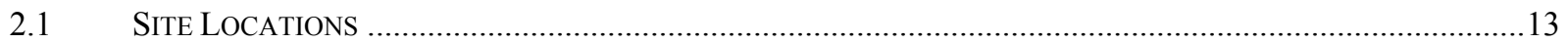

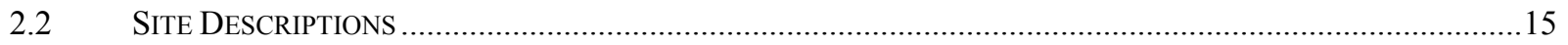

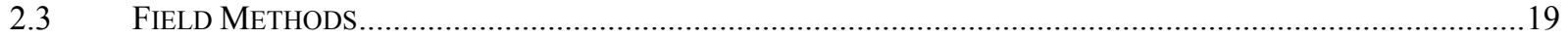

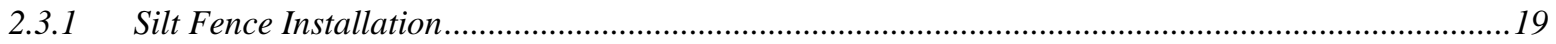

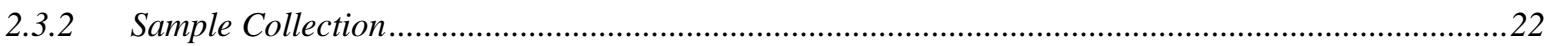

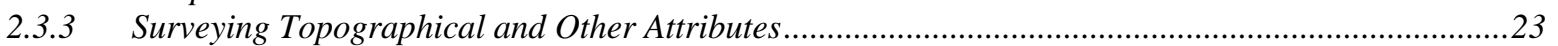

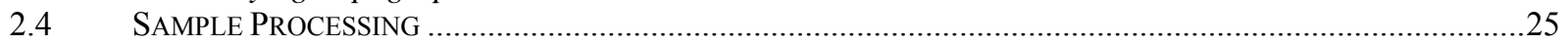

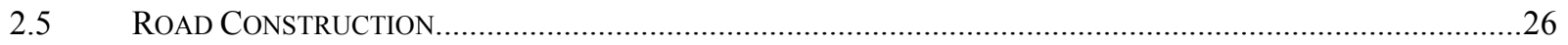

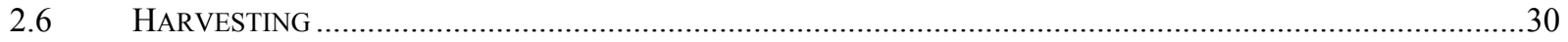

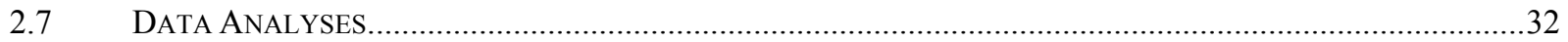

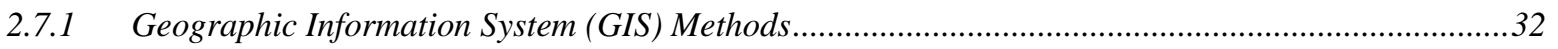

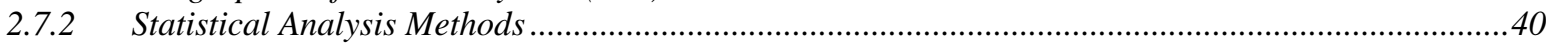

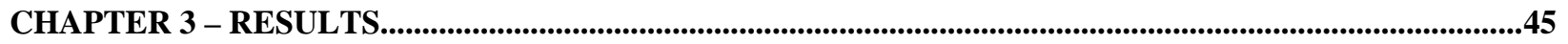

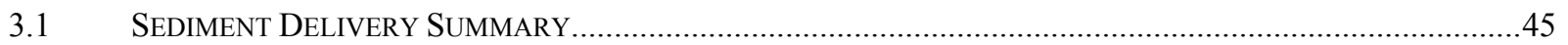

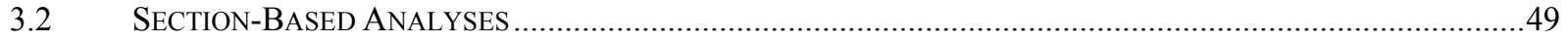

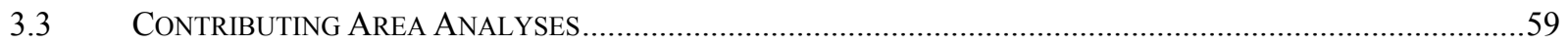

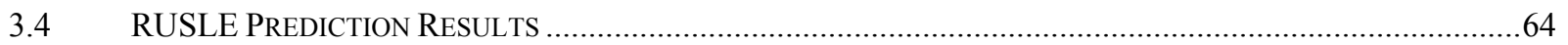

CHAPTER 4 - DISCUSSION AND CONCLUSIONS ................................................................................65

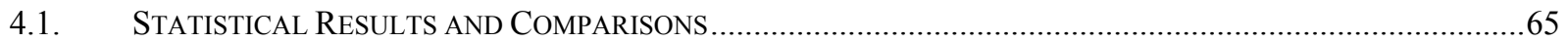

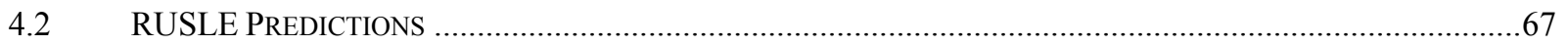

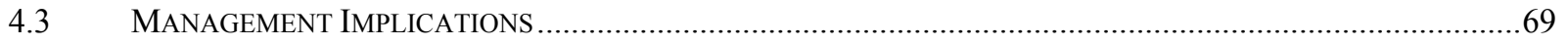

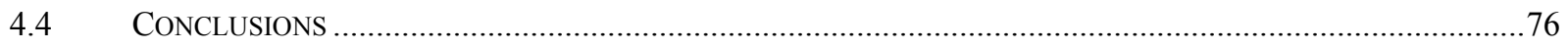

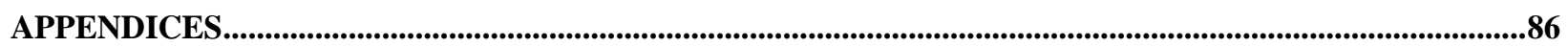

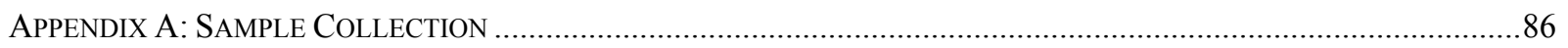

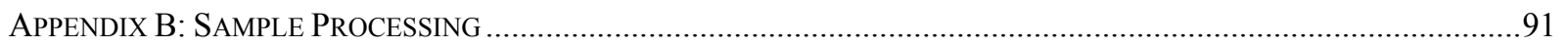

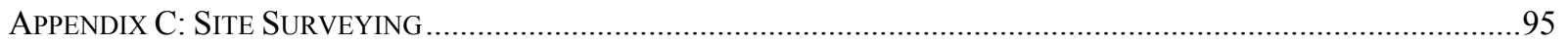

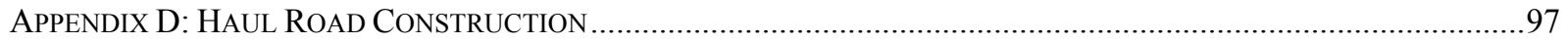

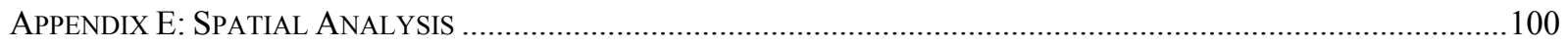

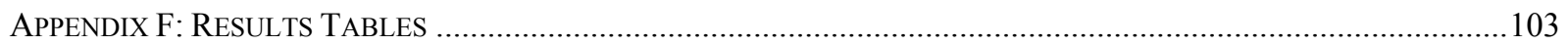

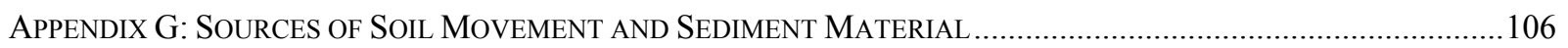

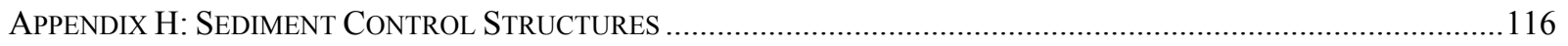




\section{LIST OF FIGURES}

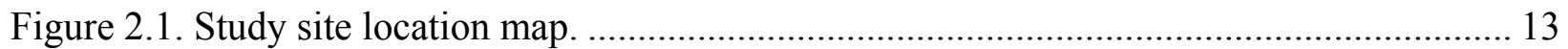

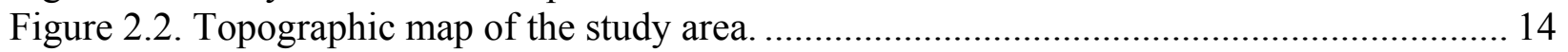

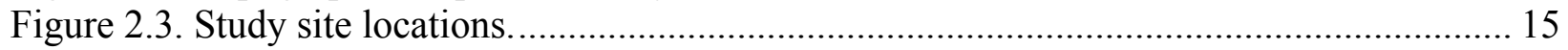

Figure 2.4. Distribution of soils within the control watershed. .................................................. 18

Figure 2.5. Distribution of soils on the treatment watershed.................................................. 19

Figure 2.6. Amoco $^{\mathrm{TM}} 1198$ silt fence installed along stream channel. ....................................... 21

Figure 2.7. Mechanical addition of sediment to silt fence as a result of road construction.......... 27

Figure 2.8. Haul road stream crossings in the treatment watershed. ........................................... 29

Figure 2.9. Second tributary diverted to flow down rip-rap channel into first stream crossing. .. 30

Figure 2.10. Harvest unit within treatment watershed............................................................... 31

Figure 2.11. Treatment watershed digital elevation map (DEM) at $3 \mathrm{~m}$ resolution..................... 33

Figure 2.12. Examples of using the raindrop tool flow path identifier for delivering sediment to

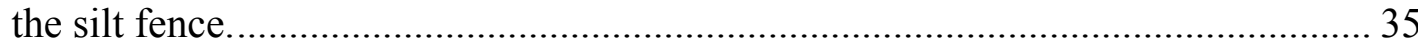

Figure 2.13. Raster grid for distance from the silt fence for the treatment watershed................. 37

Figure 2.14. Treatment watershed contributing areas............................................................. 38

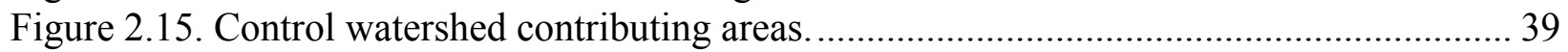

Figure 3.1. Total metric tons of sediment delivered to the silt fences each year.......................... 45

Figure 3.2. Sediment delivery expressed on an area basis for each watershed each year. ........... 46

Figure 3.3. Sediment delivery expressed on stream-length basis for each watershed each year.. 47

Figure 3.4. Sediment collected from silt fence sections located within 30.48 horizontal meters (100 feet) of the road surface in the treatment watershed..........................................4 48

Figure 3.5. Treatment watershed high and low contributing area subgroups................................ 60

Figure 3.6. Control watershed high and low contributing area subgroups.................................... 61

Figure A.1. Silt-fence installed around stream using Black Locust (Robinia psuedoacacia) posts

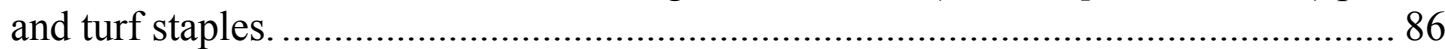

Figure A.2. Silt-fence folded up the hill to capture sediment from the adjacent hill-slopes. ....... 87

Figure A.3. Dry flow channel encompassed by silt-fence............................................................ 88

Figure A.4. Silt-fence post tagged with a brass tag and numbered with paint for sample site identification.

Figure A.5. Previously collected sample tagged with $\operatorname{Tyvek}^{\mathrm{TM}}$ tag and sample labeled with

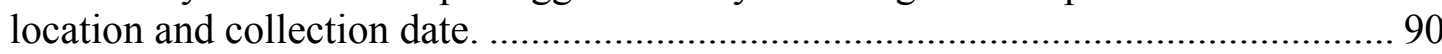

Figure B.1. Samples collected from silt-fences by hand and placed into trash bags for transport to

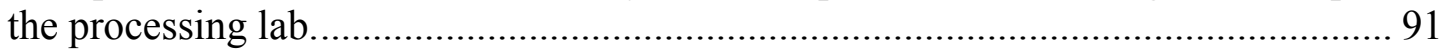

Figure B.2. Sample processing; removing organics from the sediment samples. ....................... 92

Figure B.3. Oven drying sediment samples in leaf bags........................................................... 93

Figure B.4. Mechanical sieve used to sort sediment samples into size classes; the samples were then weighed and the data recorded into a Microsoft Excel workbook....................... 94

Figure C.1. Surveying instruments; TopCon ${ }^{\circledR}$ Total Station and prism pole. ............................... 95

Figure C.2. Surveying the boundaries of a tree fall and the associated soil disturbance.............. 95

Figure C.3. All Surveyed Features Map (Treatment Watershed)................................................... 96

Figure D.1. John Deere 690 E LC Excavators used in road building process.............................. 97

Figure D.2. John Deere 650G and 650H Bulldozers used in road building process. .................... 97

Figure D.3. A front-end loader was also used throughout the road building procedures............. 97 
Figure D.4. Disturbance created during the construction of a permanent culvert-and-fill type

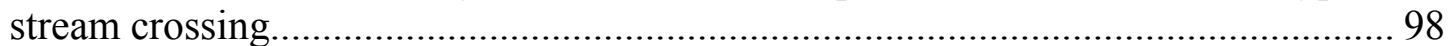

Figure D.5. Completed section of haul road in treatment watershed....................................... 99

Figure E.1. Treatment watershed flow direction raster grid (FDR) ..................................... 100

Figure E.2. Treatment watershed flow accumulation raster grid (FAC) . ............................. 101

Figure E.3. Slope Map (Degrees). ......................................................................... 102

Figure G.1. Rutting and low spot in the haul road accumulating water and sediment material;

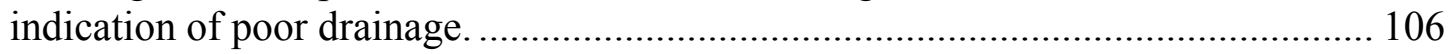

Figure G.2. Erosion of the fillslope as a result of water accumulation on the road surface...... 107

Figure G.3. Animal burrows expose soil making it more susceptible to the effects of erosion. 108

Figure G.4. Animal trails create areas of bare soil which are more susceptible to the effects of erosion due to the lack of vegetative protection. .................................................. 109

Figure G.5. Tree falls create vast quantities of disturbed, exposed soil which is easily transported to adjacent streams if not stabilized............................................................. 110

Figure G.6. Tree falls contribute large quantities of soil from rather small areas................... 111

Figure G.7. Debris slides move immense quantities of material down the slopes all at once.... 112

Figure G.8. Steep fill-slopes and embankments allow material to move easily down the slope due

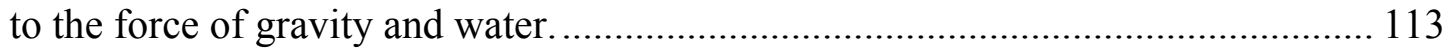

Figure G.9. Cutslope slip above road in treatment watershed. These areas can contribute to road and ditch line erosion as a result of blocking water control structures such as culverts.

Figure H.1. Properly seeded fill-slopes allow the soil underneath to stabilize and impede 114

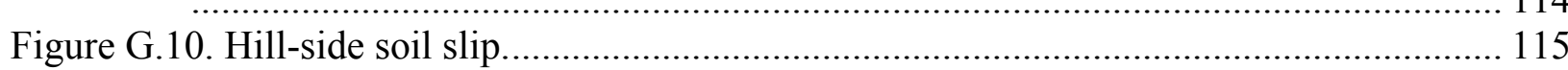
gravity and water from dislodging and transporting soil particles during common precipitation events.

Figure H.2. Hay bales and silt-fence installed below culvert to capture sediment material while still allowing the water to flow through that area............................................... 117

Figure H.3. Rip-rap installed underneath culvert outlet to reduce the force of falling water.... 118

Figure H.4. Rip-rap installed beneath culvert outflow to dissipate the force of falling water.... 119

Figure H.5. Haul Road graveled and embankments completely vegetated to aid in stabilization.

Figure H.6. Broad based dip outlet riprapped to prevent channeling of the fill-slope using

limestone rocks to prevent erosion. ................................................................ 121

Figure H.7. Flow channel redirected and lined with large limestone rock to prevent ditchline and cutslope erosion. 


\section{LIST OF TABLES}

Table 3.1. Mean mineral weight ( $\mathrm{g}$ ) of soil captured in the silt fence each year in the treatment and control watersheds.

Table 3.2. Significance levels (P-values) of independent variables tested for explaining sediment delivery to the silt fence in the section-based analysis.

Table.3.3. Mean mineral weight ( $\mathrm{g}$ ) of sediment delivery as a function of horizontal distance of the silt fence to bare soil areas. "Missing" refers to fence sections that had no associated bare soil areas.

Table 3.4. Mean mineral weight (g) of soil delivery as a function of the amount of bare soil area. "Missing" refers to fence sections that had no associated bare soil areas.

Table 3.5. Mean mineral weight ( $\mathrm{g}$ ) of sediment delivery as a function of horizontal distance from animal trails. "Missing" refers to fence sections that had no associated animal trails.

Table 3.6. Mean mineral weight (g) of sediment delivery associated with horizontal distance from tree falls. "Missing" refers to fence sections that had no associated tree falls.... 55

Table 3.7. Mean mineral weight (g) of sediment delivery associated with hillside slope. 56

Table 3.8. Mean mineral weight ( $\mathrm{g}$ ) of sediment delivery as a function of horizontal distance to WDEFs. "Missing" refers to fence sections that had no associated WDEFs.

Table 3.9. Mean mineral weight ( $\mathrm{g}$ ) of sediment delivery as a function of the horizontal distance from the road surface. "Missing" refers to fence sections that had no associated Roads.

Table 3.10. Sediment delivery associated with the horizontal distance from the fillslopes. "Missing" refers to fence sections that had no association with the fillslopes.

Table 3.11. Significance levels (P-values) for independent variables tested for explaining sediment delivery to the silt fence in the contributing area analysis.

Table F.1. Means and standard deviations for the classes of the independent variables 103 


\section{INTRODUCTION}

In comparison to agriculture and rangeland conditions, forests generally have high soil infiltration rates and relatively low potentials for runoff and erosion due to the presence of litter cover (Patric 1976, Talsma and Hallam 1980, Bonnel et al. 1983, Huang et al. 1995). However, when a forest management treatment is implemented, the resulting disturbance can change the site and increase soil erosion and movement. Some forest management operations can cause soil surface disturbance ranging from removal of the protective organic litter to the complete removal of the topsoil and even disturbance of the subsoil (Dyreness 1965). Most modern harvesting operations employ the use of heavy equipment, which in almost all cases disturbs the litter layer (Steinbrenner and Gassel 1955, Lull 1959, Froehlich 1979). Road and landing construction are the major disturbances that can increase soil erosion during forest management (Hatchell et al. 1970, Pope 1991, Croke and Hairsine 2006), but they are necessary to complete nearly all forest management and silvicultural treatments. During road construction, soil is displaced purposely by mechanized equipment, including excavators, bulldozers, and loaders. The amount of soil displaced during forest management varies based on many variables at the construction site, including natural hillside grades and lengths, road grades, road widths and lengths, geology, size, and landform of the area and the time during which the management is applied (Pope 1991, Croke and Hairsine 2006). Other types of soil disturbance are less evident and harder to recognize. For example, leaf litter can be scoured and soil exposed when trees are winched or skidded along the ground (Hatchell et al. 1970, Pope 1991, Eisenbies et al. 2005), thus, creating areas of potential accelerated erosion.

Natural soil displacement and movement are controlled by many factors, including slope length, slope steepness, geology and vegetative cover (Wischmeier 1976). The presence of 
obstructions and natural disturbances, such as slope-breaks and tree falls, and the proximity of disturbances to water bodies can be important factors to consider when evaluating erosion and deposition processes (Pope 1991, Kochenderfer and Hornbeck 1999, Croke and Hairsine 2006). In addition, precipitation characteristics, such as total amount and intensity, help determine the extent of soil movement (Florida Department of Environmental Regulation 1988).

Soil physical properties have an effect on the amount and rate of soil movement as well. Soil hydraulic properties are functions of soil texture and structure (Huang et al. 1996). Soil texture and moisture determine the amount of soil cohesion; less cohesion results in easier soil movement, and potentially sedimentation (Brown 2003).

An estimated 3.6 billion metric tons of sediment are carried to streams, ponds, lakes and rivers each year in the United States; almost one billion metric tons of this sediment is carried to the oceans annually (Florida Department of Environmental Regulation 1988). Damage to water resources from non-point source pollution was estimated to be $\$ 7$ to $\$ 9$ billion a year in the mid1980s (Ribaudo 1986, Klapproth 2000).

The majority of sediment carried by stream and river waters is transported during short periods of time and is most often associated with short duration, intense storms (Kochenderfer and Wendel 1980, Edwards and Owens 1991, Alpert et al. 1995, Breshears et al. 1999, Croke and Hairsine 2006). Kochenderfer et al. (1997) found that $90 \%$ of annual sediment loss from a small watershed in central West Virginia was exported during only $5 \%$ of the time. Edwards and Owens (1991) added that sixty-six percent of the total erosion on nine small watersheds in Ohio was produced by the five largest erosion producing events on each watershed during a 28 -year period. Flood events dominate annual sediment loadings (Beasley 1979, Edwards and Owens 1991, Kochenderfer and Edwards 1991, Stuart and Edwards 2006) in such a way that a single 
event can produce sediment quantities that exceed the sediment production amassed over several years (Kochenderfer et al. 1997). Soil particles that have been transported into a stream channel could lead to excessive sediment deposition when the energy of the water declines and sediment settles out onto the stream bottom. Excessive deposition can result in damage to aesthetics and aquatic life, obstruct navigation of waterways, reducing hydrological capacities of streams, increase stream temperatures, increase flood crests, and reduce overall stream and site production (Corbett et al. 1978, Pope 1991, Klapproth 2000, Croke and Hairsine 2006). Some watersheds in which the vegetative cover and the soil mantle have been drastically altered, have delivered 20,000 to 40,000 times more sediment than an undisturbed woodland area of the same size and makeup (Florida Department of Environmental Regulation 1988).

There are also effects that occur outside of the stream channel. Soil loss that subsequently leads to stream pollution also causes site degradation and reduces productivity, diversity, and sustainability of both plants and animals associated with forest lands. Soil movement, soil loss, and the subsequent sedimentation from forest management operations are considered by some to be major contributors to the damage to soil and water resources. Unfortunately, studies quantifying sediment delivery from hill-slope attributes to streams and the resulting damage are limited, indicating the understanding of sediment delivery processes is also limited (Croke and Hairsine 2006).

To provide some insight into the processes of sediment delivery in forests of the central Appalachians, baseline levels of sediment delivery and levels delivered under managed conditions involving roads and harvesting were analyzed and modeled to identify the topographical attributes that contribute to sediment delivery to streams. 
The main objectives of this study are to 1)identify topographic attributes that are important to controlling sediment delivery in these two forested watersheds under conditions of no anthropogenic disturbance and under conditions of forest management, which includes road construction and some limited forest harvesting; and 2)model sediment delivery using the Revised Universal Soil Loss Equation (RUSLE) and compare those results with what was actually obtained from field sampling to make some generalizations about the applicability of RUSLE to forested watersheds. 


\section{CHAPTER 1 - LITERATURE REVIEW}

\subsection{Soil Erosion Basics}

The process of soil erosion involves the detachment, transport, and subsequent deposition of soil particles (Meyer and Wischmeier 1969). Whether detachment occurs depends upon whether the shear strength and cohesion/adhesion forces are weaker than the shear stress and detachment forces for the soil in question. Transport and deposition are dependent primarily upon surface roughness and other energy controls (Meyer and Wischmeier 1969). Waterinduced erosion is affected by rainfall intensity, vegetative cover, slope of the land, length of slope, and soil properties, with the degree of influence being dependent upon local conditions at any particular site (Copley et al. 1944).

Without other disturbances, climate, soil, vegetation, and topography are the major factors that control erosion rates (Stuart and Edwards 2006, Patric 1976). However, erosion can be accelerated and elevated in forests as a result of management activities. Accelerated soil loss can be very detrimental, because maintaining soil integrity and productivity are critical to sustainable forest management (Gucinski et al. 2001). Disturbances initiated by intensive forest management can have many negative effects on the physical, chemical, and biological characteristics of soils, which in turn can reduce their long-term productivity (Gucinski et al. 2001). Declines in soil productivity caused by excessive soil erosion and exports may reduce sustainable harvest levels and detrimentally affect other watershed values, such as wildlife and aquatic population diversity, and habitat (Pope 1991, Klapproth 2000, Croke and Hairsine 2006). 


\subsection{Sediment Sources in Managed Forests}

The primary sources of sediment and water-body sedimentation in managed forest watersheds are roads and landings (Case and Donnely 1979, Kochenderfer 1977, Stuart and Edwards 2006). Erosion and sedimentation tend to be greatest during and soon after road construction while embankment soils are still loose and vegetation has yet to become established (Haupt 1959, Parson 1999). Accelerated erosion rates from roads have ranged from 30 to 300 times greater than those in undisturbed forests (Gucinski et al. 2001).

Roads have three primary effects on hydrologic processes: 1) they intercept rainfall and subsurface water moving down the hill-slope; 2) they concentrate flow, either on the surface or in an adjacent ditch or channel; and 3) they divert or reroute water from flow paths, including subsurface paths, that water would otherwise take if the roads were not present (Gucinski et al. 2001). Roads, therefore, can affect erosion and geomorphic processes by four primary mechanisms: 1) accelerating erosion from the road surface and prism itself by both mass and surface erosion processes; 2) affecting channel structure and geometry; 3) altering surface flowpaths, leading to diversion or extension of channels onto previously un-channelized portions of the landscape; and 4) causing interactions among water, sediment, and woody debris at engineered road-stream crossings (Gucinski et al. 2001).

Waterway crossings and approaches present some of the highest risks to water quality (Alpert et al. 1995) because of their proximity to the water (Kochenderfer and Hornbeck 1999), and the size of a crossing is the variable most indicative of the magnitude of the effect on water quality (Alpert et al. 1995). To limit water quality effects, bridges or adequately-sized culverts are preferable to fords at frequently used or long-term crossings (Brinker and Taylor 1997). 
Even beyond stream crossing considerations, proper road location is critical to reducing erosion (Swift 1988, USDA 1999). Yoho (1980) found sediment yields varied by a factor of 25 depending upon road and skid trail system locations. Roads laid out on the contour typically result in substantially less erosion than steep roads. Hornbeck and Reinhart (1964) found that skid trails placed perpendicular to the contour on severe slopes in the Appalachians resulted in 100 metric tons/ha (40 tons/ac) of sediment during the first year after harvesting. Thus, proper planning of the road system prior to construction is critical to reducing erosion and sedimentation, and it is typically more cost effective than constructing roads with no preplanning (Kochenderfer et al. 1997).

Road drainage (Haupt 1959), surfacing (Burroughs and King 1989, Kochenderfer and Helvey 1987, Swift 1984), and cut-and-fill slope treatments (Burroughs and King 1989, Swift 1988) are also important to reducing erosion, which is why state Best Management Practices (BMPs) often focus on these activities. Reducing water volumes and velocities are essential to controlling the kinetic energy of water (Croke et al. 199b, Croke and Hairsine 2006). Roaddrained water can be kept to small volumes by adequately spacing water control features, such as water bars, broad based dips, cross drain culverts, and open top culverts (WV DOF 2005). Road surfacing materials and vegetation establishment can increase roughness, thereby decreasing water's energy and ability to dislodge and transport sediment from the road prism (Beschta 1978, Burroughs et al. 1984, Kochenderfer and Helvey 1987, Swift 1984).

It should be noted that most sediment produced from road prisms, or even elsewhere in forests, primarily comes from small definable areas (Bonnell and Williams 1986, Croke et al. 1999b, Croke and Hairsine 2006). For example, major erosional features occupied only 0.6 percent of the length of roads studied by Rice and Lewis (1986) in the Klamath Mountains of 
northwestern California. Because contributing sources are small and definable, they also can be treated more easily.

\subsection{Soil Characteristics}

To understand the effect that soil characteristics and erosion have on soil productivity, land managers need a working knowledge of soils (Miller and Tidman 2001). Each soil has a unique combination of properties, with some soil characteristics affecting the degree and rate of soil erosion. Soil texture is an important characteristic in the consideration of erodibility and land use management in general. Texture refers to the mixture of particle sizes in a soil (Brown 2003). By definition, soil is mineral particles that are $\leq 2 \mathrm{~mm}$ in diameter. These mineral particles are defined in three different classes based on particle size. The classes less than $2 \mathrm{~mm}$ are sand $(0.05 \mathrm{~mm}$ to $2.0 \mathrm{~mm})$, silt $(0.002 \mathrm{~mm}$ to $0.05 \mathrm{~mm})$, and clay $(<0.002 \mathrm{~mm})$ (USDA Field Guide to Soil Texture Classes, 2006). Mineral particles that are $>2 \mathrm{~mm}$ in diameter do not constitute soil, but they, along with organic matter, are classified as soil materials due to their influence on water retention, infiltration, and runoff(Brown 2003). These coarse particles are classified as various gradations of gravel, cobbles, or boulders, depending on their size. More sediment is produced from finer textured soils, excluding clays, because clays form larger aggregates (Parson, 1999). Finer textured soils are more easily moved by surface runoff and raindrop splash than are large particles (Wall et al. 2003).

Soil texture and structure influence drainage and soil moisture holding capacity (Huang et al. 1995), as well as the cohesive/adhesive forces among particles, all of which affect soil erosion potential (Jones 2003). Finer texture soils, such as clays, have very small pore size, and thus, retain more water per volume of soil, all other things being equal. 
Because the likelihood that soil disturbance is enhanced on moist to saturated soils (Moehring and Rawls 1970, Greacen and Sands 1980), soil compaction, rutting, and puddling typically increase during heavy equipment use during forest management operations (Jones 2003, Rachael and Karr 1989, Turcotte et al. 1991). Furthermore, ruts can be extended and expanded and result in extensive gullying in the presence of overland flow, particularly during intense rain events (Jones 2003, Rachael and Karr 1989, Turcotte et al. 1991). Soil compaction and loss of organic matter from the forest floor directly influence mineral weathering rates (Zabowski et al. 2000, Wang 2005). Soil compaction also increases bulk density and restricts water infiltration and can result in substantial increases in overland flow, which in turn increases water's ability to dislodge and transport soil particles (Harr et al. 1979, Jaakko Pöyry 1992, Froehlich and McNabb 1984, McNabb et al. 2001). Severely compacted and damaged soils may require up to 40 years or more to recover naturally; thus, compaction could significantly prolong erosion and retard root stabilization processes during that time (Hatchell and Ralston 1971).

\subsection{Soil Loss Equations}

Estimating the potential effects of management-induced erosion often depends upon estimating soil loss. Soil loss equations are used commonly to estimate erosion from an area or watershed. The most commonly used soil loss prediction method is the Universal Soil Loss Equation (USLE) (McCool et al. 1982, Renard et al. 1991, Hood et al. 2002). In the USLE, soil loss (tons/ac/yr) is a function of rainfall erosivity $(\mathrm{R})$, soil erodibility $(\mathrm{K})$, slope length $(\mathrm{L})$, slope steepness (S), cover management (C), and supporting practices (P). The $\mathrm{R}$ value is the effect of raindrop impact on runoff (Risse et al. 1993), which can be determined using Wischmeier and Smith's (1965) map of isoerodent lines of erosion index units (EI) for the United States 
(Dissmeyer and Foster 1984). The K value reflects a soil's susceptibility to erosion, and coefficients for K are available for most soil types from U.S. Natural Resources Conservation Service (Hood et al., 2002). The L and S factors are combined using:

$$
\mathrm{LS}=(\gamma / 72.6)^{\mathrm{m}}\left(65.41 \sin ^{2} \theta+4.65 \sin \theta+0.065\right)
$$

where gamma $(\gamma)$ is equal to the angle of slope in degrees; and $m=0.2$ for gradients less than $1 \%$, 0.3 for $1-3 \%$ slopes, 0.4 for $3.5-4.5 \%$ slopes, and 0.5 for slopes of $5 \%$ and greater. The slope length can simply be measured by pacing. The $\mathrm{CP}$ factor (combined $\mathrm{C}$ and $\mathrm{P}$ ) is the product of several sub-factors and represents a management practice factor for tilled or untilled soils (Hood et al., 2002). The USLE was developed for agricultural lands with slopes no steeper than 18 percent (McCool et al. 1982). However, it was later updated in new versions to incorporate forested lands (Dissmeyer and Foster 1981).

Soil losses predicted from USLE are simply estimates of soil movement, but are not synonymous with delivery of sediment to stream channels. Gianessi et al. (1986) estimated that the ratio of gross erosion to in stream sediment delivery for forestlands is 0.50 and 0.52 for Virginia and West Virginia, respectively (Hood et al., 2002). Also, the USLE predicts only sheet and rill erosion (Hood et al. 2002) but excludes other types of erosion that may occur, such as gully erosion. Sheet erosion is the uniform removal of soil in thin layers by the forces of raindrops and overland flow (topsoil.nserl.purdue.edu/fpadmin/weppmain/overview/sheet.html), Rill erosion is the removal of soil by concentrated water running through little streamlets, or headcuts (topsoil.nserl.purdue.edu/fpadmin/weppmain/overview/rill.html), and Gully erosion results from water moving in rills, which concentrate to form larger channels or gullies (dhn.iihr.uiowa.edu/runoff/erosion.htm). 
The USLE estimates average soil erosion for an entire watershed, but bases this loss/movement on linearity of slopes. In actuality, slope length and steepness are nonlinear, nor are they uniformly distributed over an entire watershed (Wilson 1986, Castro and Zobeck 1986). Slopes may have concave, convex and/or linear parts associated within them, and failure to correct for slope shape could lead to errors in estimating the $\mathrm{L}$ and $\mathrm{S}$ factors (Castro and Zobeck 1986). Wilson (1986) further noted that the $\mathrm{K}$ and $\mathrm{C}$ values may not be uniform for an entire watershed and certainly are not uniform with respect to the $\mathrm{L}$ and $\mathrm{S}$ factors for the same area. $\mathrm{He}$ described using topographic map data as inputs to break the slope lengths into segments consisting of common factors, which would help compartmentalize the watershed. The input of these compartments may generate a more accurate representation of soil displacement within a watershed, instead of using average values for the entire watershed.

Since the USLE was intended for cropland and the erosion estimates for sheet and rill erosion often were predicted improperly for other land uses, additional modifications were made to the USLE. Two major modifications of the USLE included the revised universal soil loss equation (RUSLE) and the modified universal soil loss equation (MUSLE). These allowed for expanded use, such as for rangeland and road erosion (Renard et al. 1991).

The RUSLE fills gaps that were present in the original data and corrects errors by providing improved coefficients. It also incorporates more data from different locations and types of cropping systems than the USLE. The RUSLE is also more flexible than the original USLE, which allows modeling of significantly more complicated systems, including rangeland and forests. One adjustment made for RUSLE is the addition of a factor that accounts for surfaces covered by or embedded with mulch and/or rock fragments (Weltz et al. 1987). The RUSLE is the most widely used method of predicting soil loss in forestry applications (Lane et 
al. 1992, Hood et al. 2002). It allows foresters to compare potential soil loss resulting from different harvesting scenarios and evaluate which method is likely to result in the least soil erosion (Hood et al. 2002). However, as noted by McCool et al. (1982), in mountainous regions with slopes $\geq 25$ percent, the L and $\mathrm{S}$ factors are speculative. Additionally, RUSLE itself is not designed to estimate erosion from road surfaces.

The MUSLE improves on the USLE by considering surface runoff and road erosion (Barfield et al. 1983). It was developed to model sediment delivery where deposition was expected down slope before reaching a waterbody. Essentially, the model takes into account the sediment deposited before reaching the waterbody downslope, thus, eliminating this sediment from its final soil loss prediction.

Another popularly used soil loss model that accounts for local soil, climate, ground cover, and topography is the Water Erosion Prediction Project (WEPP) model (Foster and Lane 1987, Laflen et al. 1991). The WEPP model can simulate erosion factors, such as vegetative status of an area, the initial moisture content of the soil, and the surface conditions. The WEPP model predicts if runoff will occur and subsequently determines the flow path. The runoff path has associated rates of erosion and deposition, determined for a predetermined number of points on the surface of the runoff path. With this information, the program calculates the total yield for that particular slope. The WEPP model, or modules of it (WEPP ROADS), has been validated on a limited basis for roads within forested environments (Elliot et al.1995, Tysdal et al. 1997). The largest disadvantage for the WEPP model is that more than 400 input variables are needed. This fact alone discourages many users and absorbs large amounts of time and money (Elliot et al. 1999) and is why it will not be tested in this study. 


\section{CHAPTER 2 - MATERIALS AND METHODS}

\section{$2.1 \quad$ Site Locations}

The two study watersheds were located in the Cheat Ranger District of the Monongahela National Forest (MNF) on the Left Fork of Clover Run in Tucker County, West Virginia (Figures 2.1, 2.2, and 2.3). One watershed is a treatment watershed, and one is an undisturbed control. The treatment watershed is located on the Montrose quadrangle map and the control watershed is located on both the Montrose and the Colebank quadrangle maps.

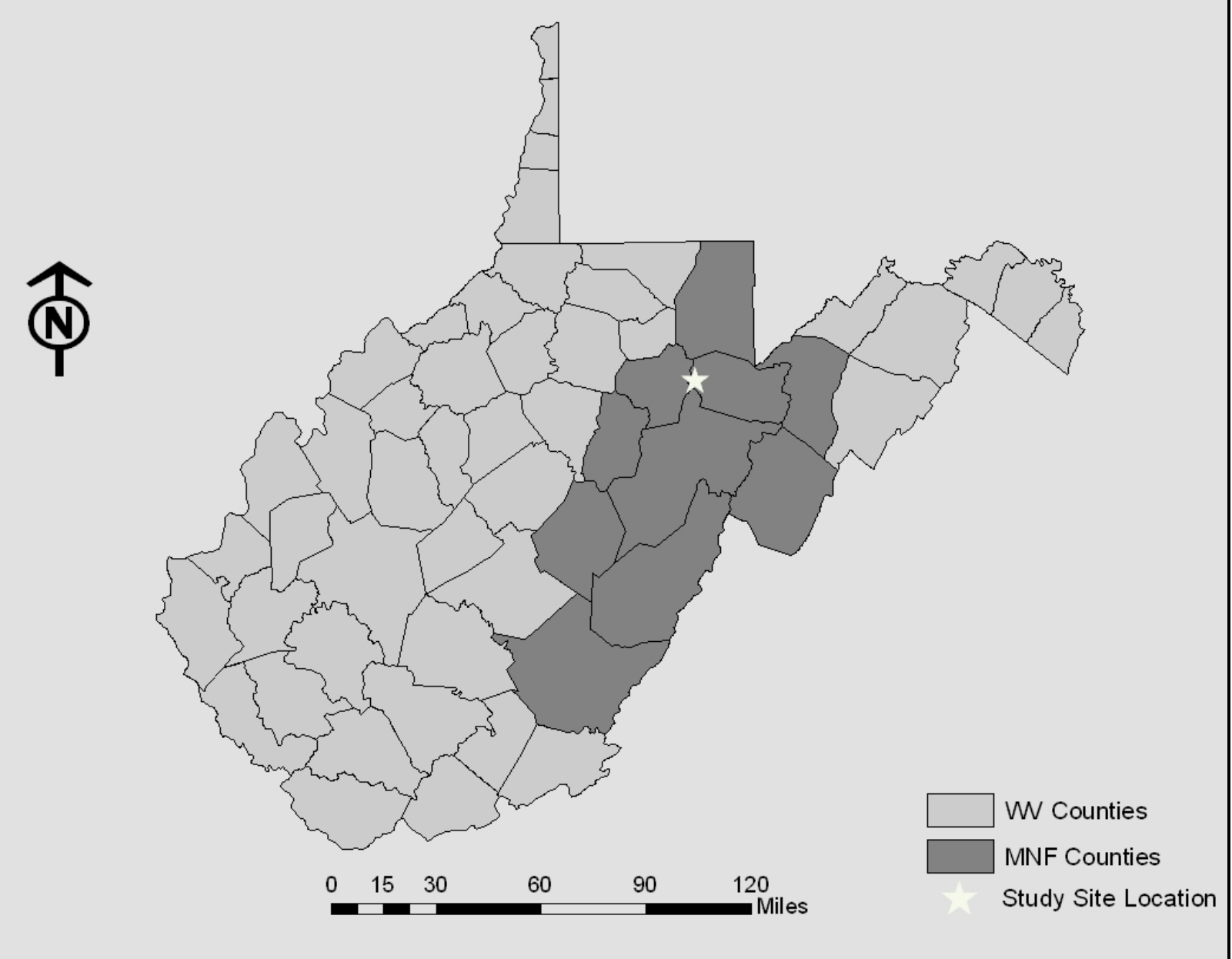

Figure 2.1. Study site location map. 


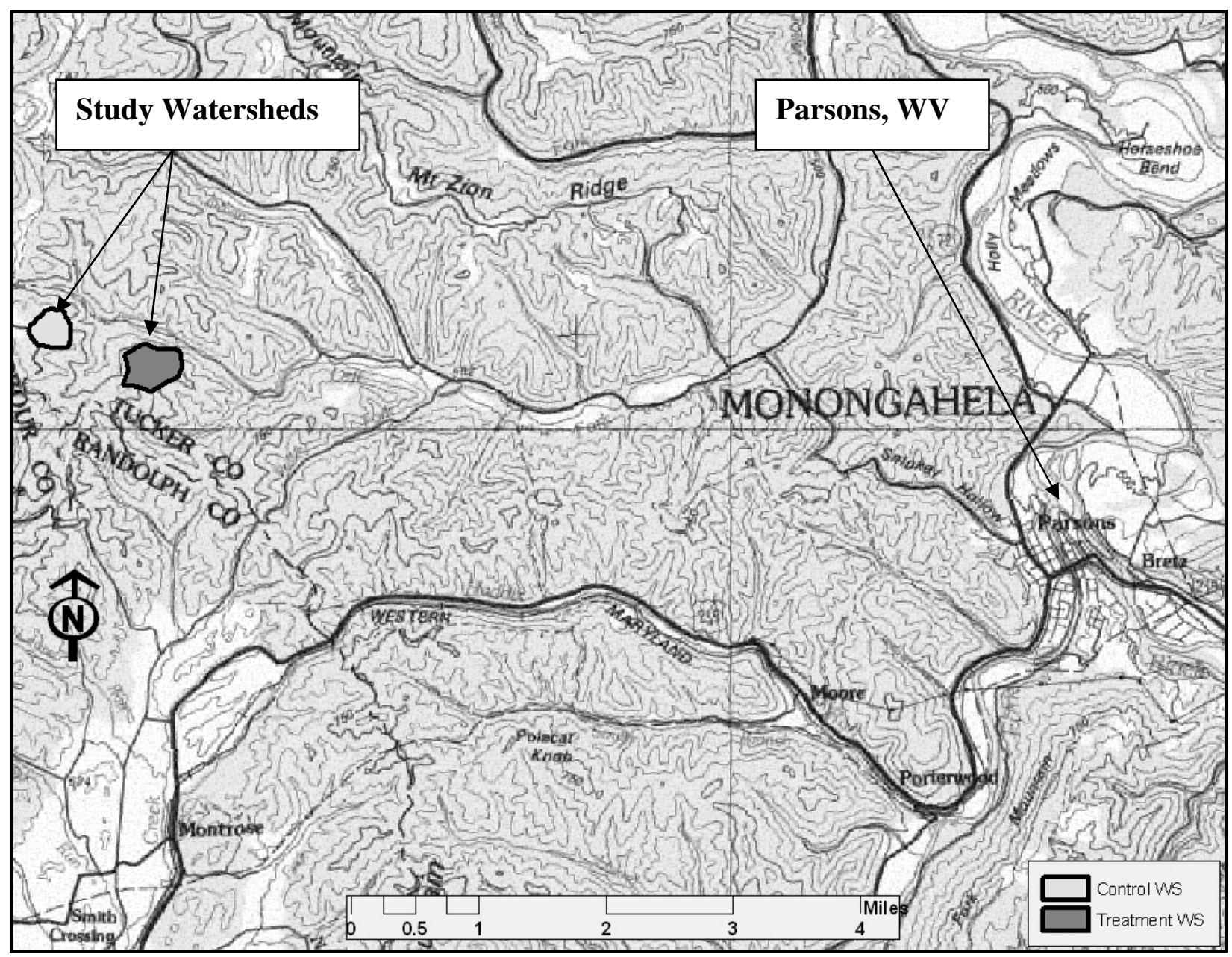

Figure 2.2. Topographic map of the study area. 


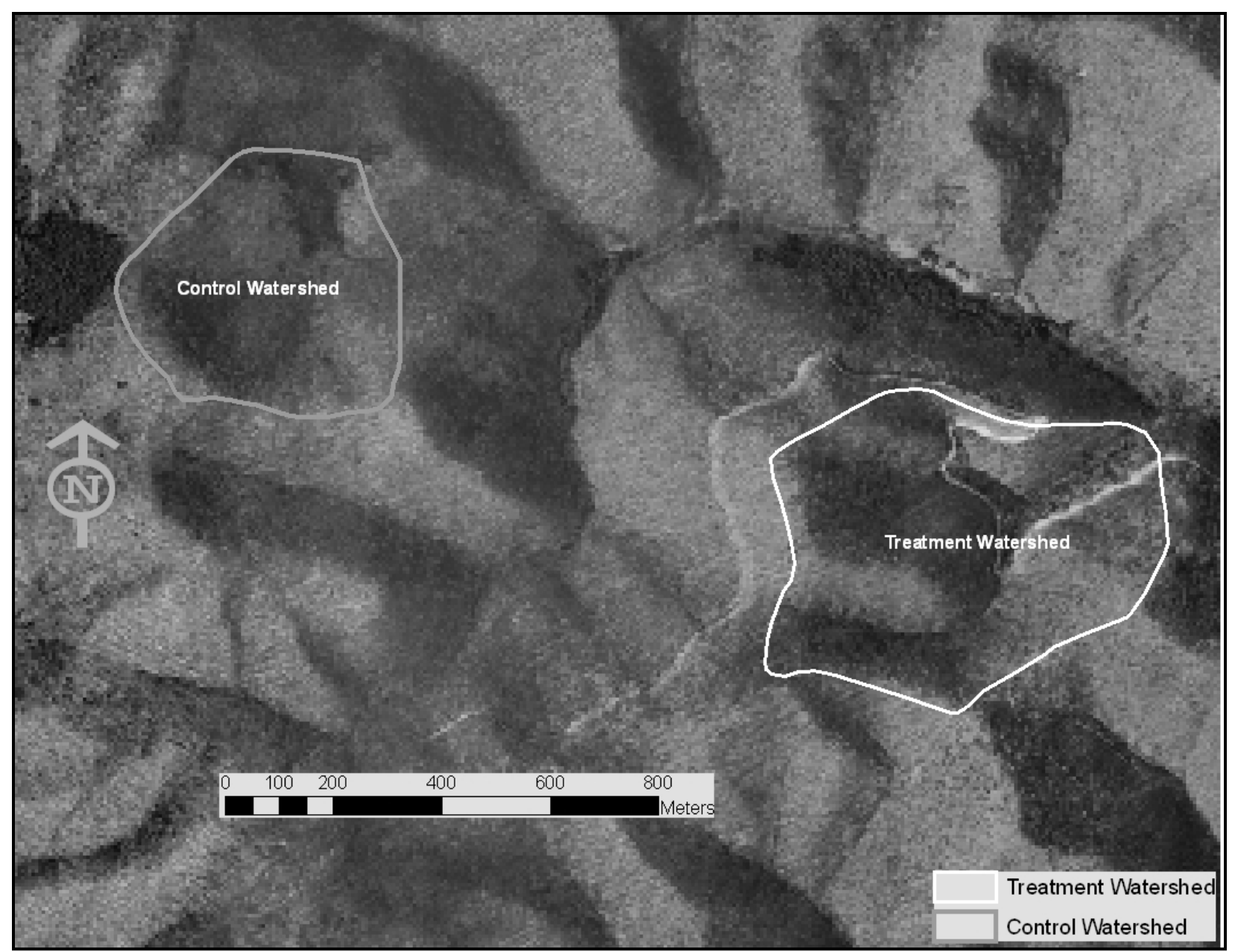

Figure 2.3. Study site locations.

\subsection{Site Descriptions}

The control watershed is 20.2 ha (50.0 ac) and the treatment watershed is 32.7 ha $(80.8$ ac). Total stream length (i.e., total of all tributaries) in the control watershed is $905 \mathrm{~m} \mathrm{(2969 \textrm {ft } )}$ and $1265 \mathrm{~m}(4150 \mathrm{ft})$ in the treatment watershed. In the control watershed, the stream channel area is 0.27 ha and in the treatment watershed the channel area is 0.37 ha; areas obtained from field survey. Elevation ranges from $713.6 \mathrm{~m}$ (2341.21 feet) to $858.7 \mathrm{~m}$ (2817.26 feet) in the control watershed, and from $625.7 \mathrm{~m}$ (2052.82 feet) to $805.1 \mathrm{~m}$ (2641.40 feet) in the treatment watershed. Hillside slopes are similar for both watersheds. Based on available $3 \mathrm{~m}$ digital 
elevation maps (DEMs) for the two watersheds, slopes on the control watershed ranges from nearly flat ( 0.21 degrees) to 44.25 degrees $(0.37 \%$ to $97 \%)$ with a mean hillside slope of approximately 22 degrees (40\%). The treatment watershed slopes range from $0.42-47$ degrees $(0.73 \%$ to $107 \%)$ with a mean slope of approximately 25 degrees (47\%). Overall, the control watershed is oriented east, and the treatment watershed is oriented northeast.

The two study watersheds were fully forested at the initiation of the study and dominated by mixed Appalachian hardwoods. Dominant species were northern red oak (Quercus rubra), yellow-poplar (Liriodendron tulipifera), sugar maple (Acer saccharum), black cherry (Prunus serotina), and yellow birch (Betula alleghaniensis) (Bill 2005). Average annual precipitation for the study areas from the calendar years of 1980-2002 was $160.33 \mathrm{~cm}$ (63.12 in) (Bill 2005, USDA Forest Service 2002). The mean daily, mean daily maximum, and mean daily minimum air temperatures from January 1959 to October 1971 were $8.5^{\circ} \mathrm{C}, 14.1{ }^{\circ} \mathrm{C}$, and $3.6^{\circ} \mathrm{C}$, respectively (Bill 2005, USDA Forest Service 2002).

Prior to the initiation of this study, the control watershed had an old road that crosses the stream. This road predates the 1930s, when the land was acquired by U.S. Forest Service. However, the road is well stabilized with numerous small trees $(5-20 \mathrm{~cm} \mathrm{DBH})$ growing in the road travel way (Bill 2005). The road is water barred for drainage control (Bill 2005) and only used to access to this study area using foot travel and ATVs (use by the latter is infrequent). All data for this study were gathered upstream of the road crossing so the crossing would not influence the results.

Both study watersheds are underlain by Chemung geology. Four soil series are present on both the treatment and control watersheds. The watersheds consist of the Brownsville-Berks, 
Laidig, Highsplint-Berks, and Berks-Highsplint soil series and associations (Tony Jenkins, USDA-NRCS Soil Survey Division, 2004, personal communication).

The Laidig series is extremely flaggy, containing appreciable quantities of flagstones (Soil Science Society of America 2007), with very deep well drained soils formed in colluvium from sandstone, siltstone, and some shale. Soil permeability is moderate or moderately rapid above the fragipan and moderately slow or slow in the fragipan. The potential for surface runoff is negligible to very high. These soils occur on slopes ranging from 0 to 30 degrees( 0 to 55 percent) (USDA NRCS 2003).

The Brownsville-Berks complex is extremely flaggy. The Brownsville series consists of deep, well-drained soils with moderate or moderately rapid permeability. Brownsville soils are formed in colluvium and residuum weathered from fractured siltstone and very fine grained sandstone. Slopes range from 2 to 70 percent. The Berks series consists of moderately deep, well-drained soils formed in residuum weathered from shale, siltstone and fine grained sandstone on rounded and dissected uplands. Permeability is moderate or moderately rapid. The potential for surface runoff is negligible to high. Slope ranges from 0 to 44 degrees ( 0 to 80 percent) (USDA NRCS 2003).

The Highsplint-Berks and Berks-Highsplint associations are extremely flaggy and extremely steep. The Highsplint series consists of deep, and very deep, well-drained soils on mountains and hills. These soils formed in stony, loamy colluvium weathered from sandstone, siltstone, and shale. Permeability is moderate or moderately rapid. The runoff class for the Highsplint series is low or medium on moderate slopes, and medium or high on steep to very steep slopes. Slopes range from 3 to 45 degrees ( 5 to 100 percent), but are dominantly 19 to 42 degrees (35 to 75 percent) (USDA NRCS, 2003). 
On the control watershed, the Laidig soil series comprises 4.92 ha (12.17 ac) of the total area, the Highsplint-Berks association 8.29 ha (20.49 ac), the Berks-Highsplint association 0.58 ha (1.43 ac), and the Brownsville-Berks complex 6.31 ha (15.61 ac) (Figure 2.4).

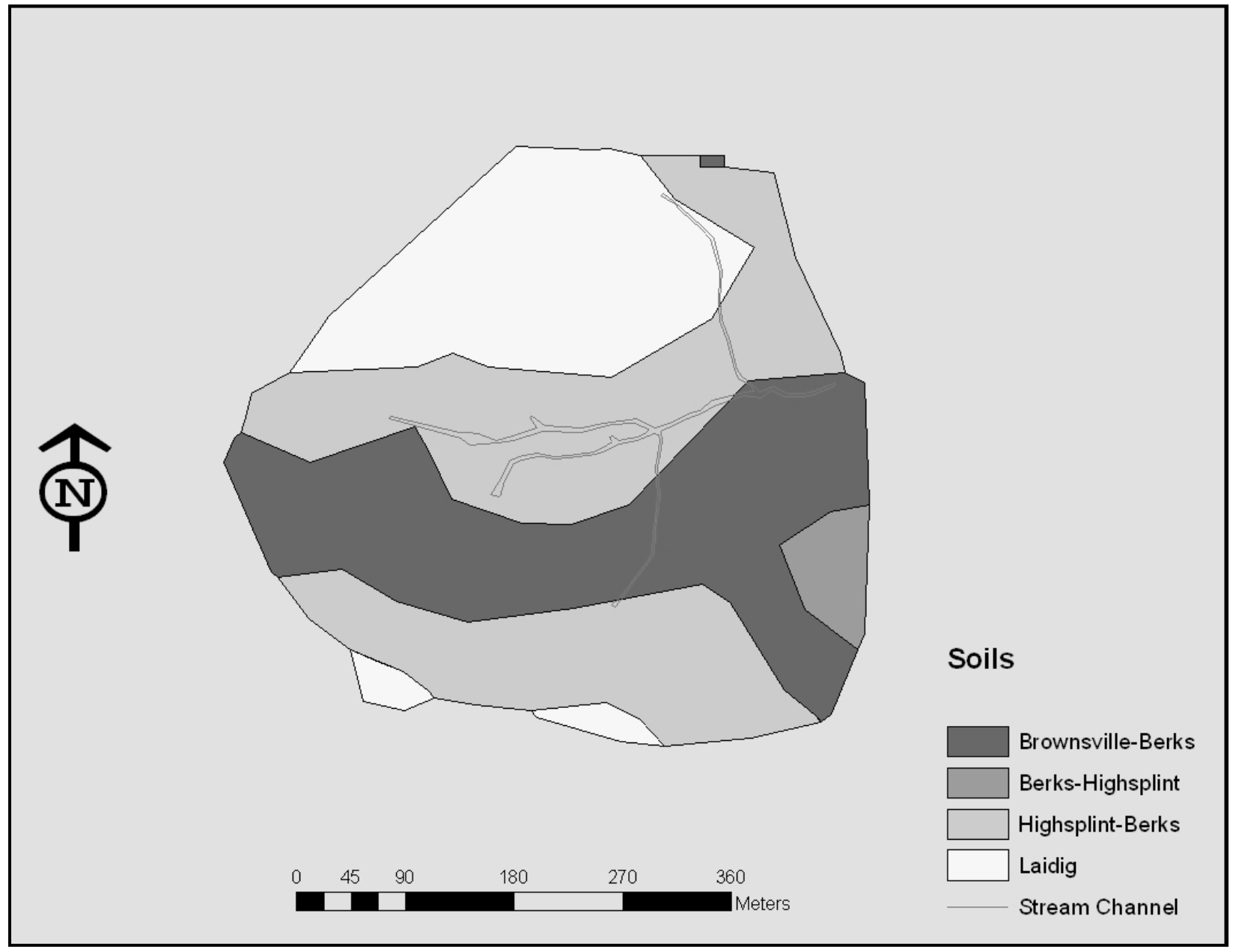

Figure 2.4. Distribution of soils within the control watershed.

On the treatment watershed, the Laidig series comprises 0.75 ha (1.85 ac), the HighsplintBerks association 14.48 ha (35.8 ac), the Berks-Highsplint association $4.92 \mathrm{ha}(12.17 \mathrm{ac})$, and the Brownsville-Berks complex makes up 12.59 ha (31.12 ac) (Figure 2.5). 


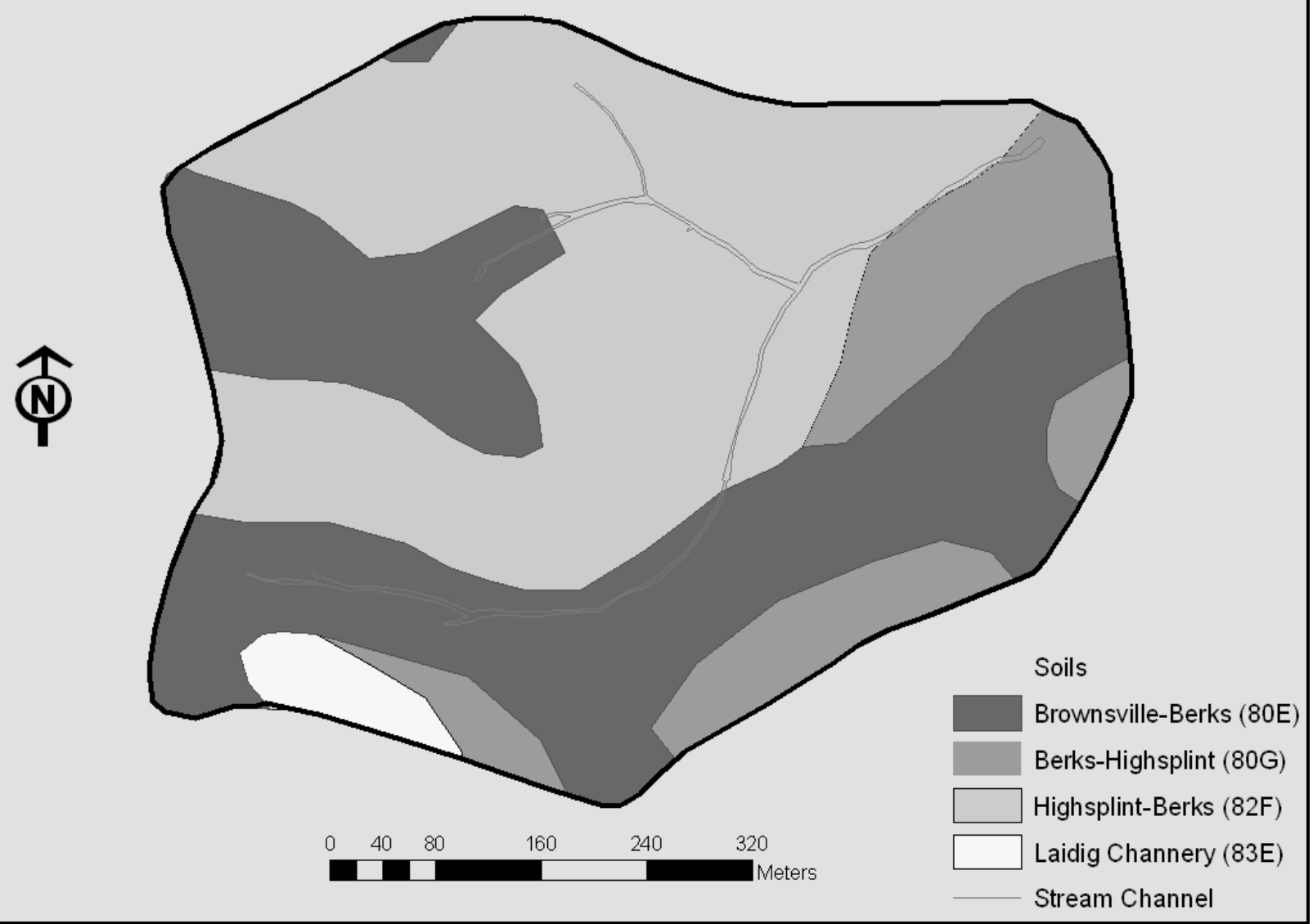

Figure 2.5. Distribution of soils on the treatment watershed.

\subsection{Field Methods}

\subsubsection{Silt Fence Installation}

Silt fence was used to collect and quantify the sediment delivered to the stream channels from the adjacent hillsides. Amoco ${ }^{\mathrm{TM}} 1198$ silt fence was chosen because of its high resistance to breakdown by UV radiation. The study was intended to continue for about a decade, so longlasting fencing was desired to avoid the need for replacement during the study. The fence material did not break down during the study and the only sections that required replacement were those that became impaled by large branches from broken tree tops. 
Silt fence was installed just upslope from the bankfull position along both sides of the entire stream channel, including ephemeral, intermittent, and perennial reaches in both watersheds. This position, just above bankfull, was far enough away from the stream channel to prevent high flow water from undercutting the edges of the silt-fence and displacing material which has been previously captured in the silt-fence. It also was considered close enough to the channel to assume that sediment that reached the fence likewise would have reached the channel in a reasonably short period of time. In some locations, the fence had to be moved slightly (usually only a few meters) further upslope because bedrock was too close to the surface near the stream, and the posts to which the silt fence was attached could not be driven in the ground. Black locust (Robinia pseudoacacia) posts ( $5 \mathrm{~cm} \times 5 \mathrm{~cm} \times 122 \mathrm{~cm}$ ), which were sharpened on one end, were driven into the ground using a sledge hammer at a spacing of approximately 1.5 to $3 \mathrm{~m}$ (6-10 ft) onto which to secure the silt fence.

The silt fence was installed differently than typically done to reduce the amount of site disturbance around the stream and to provide a consistent and known sampling area from year to year. Rather than digging a trench and burying the bottom third of the silt fence into the ground, approximately $0.3 \mathrm{~m}$ (12 in) of the silt fence was placed onto the ground, which had been cleared of sticks and leaves, in an upslope direction. The upslope edge of the silt fence on the ground was affixed to the soil using $15.2-\mathrm{cm}$-long $\times 2.54-\mathrm{cm}$-wide $(6 \times 1$ in) metal turf staples approximately every $0.15-0.30 \mathrm{~m}$ (6-12 in) (Figure 2.6). The remaining portion of the silt fence $(\sim 0.6 \mathrm{~m})$ then was attached to the posts using a fuel-cell powered staple gun and 3.3-cm-long (1.5 in) galvanized staples. During the study, maintenance of the silt fence was performed as needed to reattach the fence to the posts and to re-secure the silt fence to the ground. 


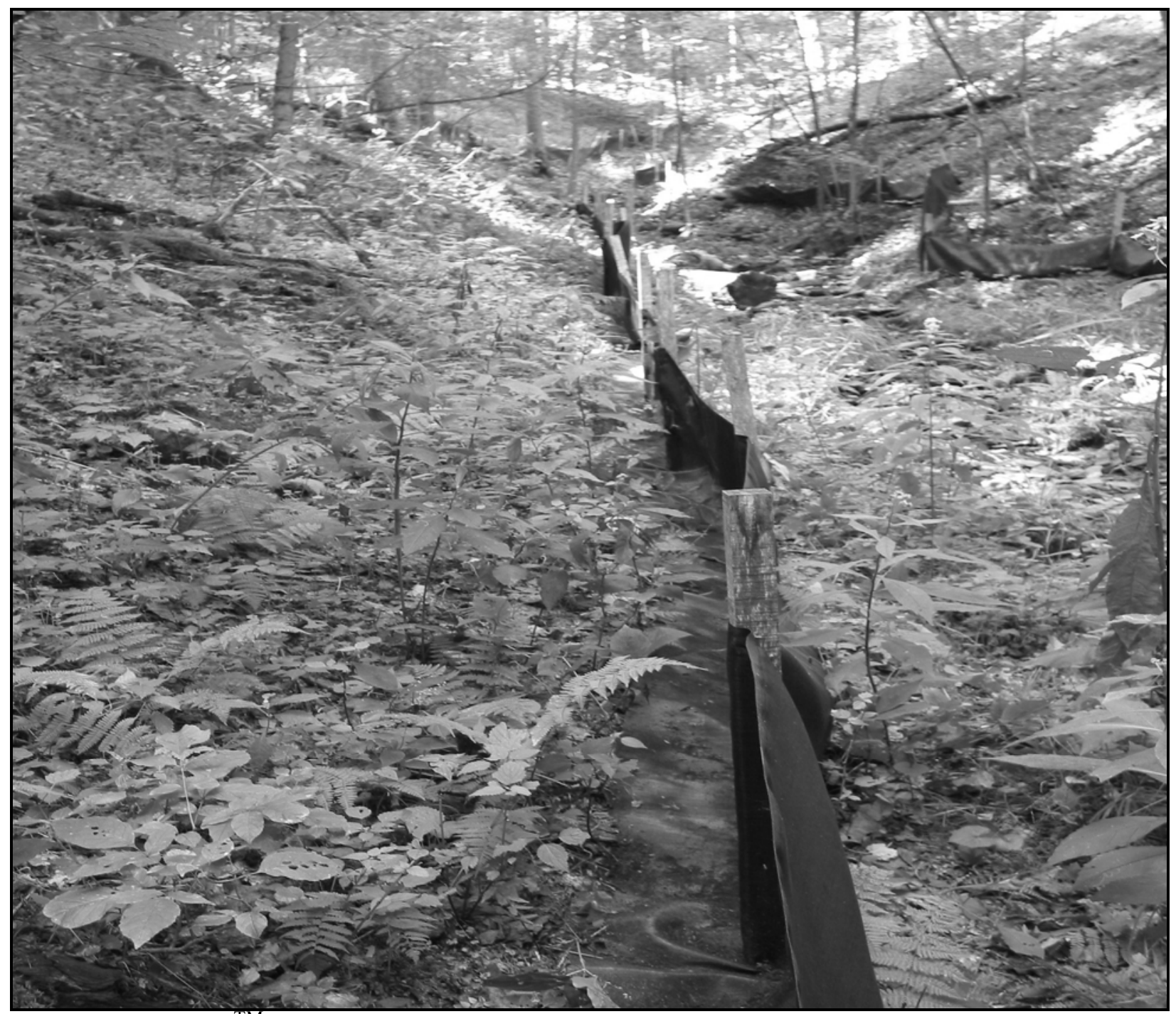

Figure 2.6. Amoco ${ }^{\mathrm{TM}} 1198$ silt fence installed along stream channel.

Uniquely numbered brass or aluminum tags were nailed to the tops of selected posts.

These numbers were used to identify silt fence sections, so when samples were collected their location would be known and could be associated with field attributes. Once selected, these section demarcations remained permanent for the duration of the study, except when sections were obliterated permanently, such as sections coinciding with stream crossings created during road construction on the treatment watershed. Post numbers also were written on the silt fence 
adjacent using Paint Stik ${ }^{\mathrm{TM}}$ to make the section numbers more visible. The right side of the stream channel (looking downstream) had even numbered tags, while the left side had odd numbered tags. The decision of which posts to tag was somewhat arbitrary, and was based upon the distances needed to fill one sample bag (described below) during fall 1999, about two months after the silt fence was fully installed.

\subsubsection{Sample Collection}

Sample collection was performed annually during summer and/or early fall for both watersheds. All of the material (both mineral and organic) laying on the portion of the silt fence stapled to the ground was removed by hand and placed into $0.12 \mathrm{~m}^{3}$ (32 gal) polyethylene garbage bags. If only a portion of a piece of material, such as a stick was laying on the silt fence, only that portion of the material was collected, and the portion off the fence was left in place. If a rock was partially overlaying the fence, it was collected since it could not be broken in two. As many collection bags as needed were used per section.

A Tyvek ${ }^{\mathrm{TM}}$ tag with the watershed, section number, date, and bag number information recorded on it was place into each bag. Where mineral sediment accumulations in a single section of fence were substantial, the samples were collected in plastic buckets, rather than bags, to avoid bag tearing and sample loss. Tyvek ${ }^{\mathrm{TM}}$ tags also were placed in the buckets. Records of the numbers of bags and buckets collected from each section also were kept in a field notebook. Information about the source of mineral sediment, when obvious (e.g., tree falls), also was recorded by section in the field notebook.

If any sample material had to be removed during silt fence maintenance, such as if a tree fell on top of and collapsed the silt fence, the material was collected at the time of maintenance 
and tagged with its respective location. This sample was later combined with the rest of the samples collected from that section that year

The treatment watershed 2002 samples represent the period prior to the initiation of road construction. The 2003 samples represent the period from the beginning of road construction to when the road was pioneered. The 2004 samples represent the period from when the road was completed by bringing it to proper grade, smoothing and graveling the surface, constructing cutbanks to final slope, and seeding the cutbanks and fillslopes. Harvesting a small area (2.83 ha) along the ridge near the last stream crossing also occurred during this period. The 2005 samples represent the period when no activities were performed and the road and other disturbances were presumably stabilized or in the process of stabilizing.

\subsubsection{Surveying Topographical and Other Attributes}

The position of the tagged silt fence posts, the stream banks, and other topographical attributes believed to be potentially important to controlling or contributing to sediment delivery were mapped in both watersheds using a TOPCONTM GTS-223 total station and a tilting prism. The attributes considered significant to contributing or controlling erosion and sediment delivery were determined based on field observations as well as information from associated literature. These included: road driving surfaces, road cutbanks and fillslopes, road cross drain features (broad-based dips and culverts), skid trails and landing positions, slope breaks, areas of bare soil (naturally bare of organic litter or other soil cover), tree falls (i.e., the root wad), animal trails, seeps, springs, washes, slips, slumps, tree drag lines (from removal of trees felled into the stream on the treatment watershed), and rock piles.. Each of these features were mapped and classified as distinct features. Each year, new features or changes to features were surveyed (e.g., new tree 
falls or some animals rerouted their trails near stream crossings after the road was constructed in the treatment watershed); therefore, survey data were collected that were specific and relevant to each year's sample collection.

All of these features were mapped appropriately as points (silt fence posts only), line segments, or polygons. The attribute polygons, poly-lines, and points were then entered into the Geographic Information System (GIS), projected, and maps of each watershed were created. Each year, changes to the maps were made as new attributes were created or obliterated; therefore, different maps were constructed that were specific and relevant to each year's sample collection.

The total station surveys provided X (easting), Y (northing), and Z (elevation) coordinates for each point measured. The data then were entered into the ESRI ${ }^{\circledR}$ GIS program $\operatorname{ArcMap}^{\circledR}$, where it could be projected and analyzed. The data were projected using the North American Datum (NAD) 1927 Universal Transverse Mercator (UTM) Zone 17 North coordinate system. At the time of data collection, this was the United States Department of Agriculture Forest Service (USDA FS) standard. The data were later re-projected in the NAD 1983 UTM Zone $17 \mathrm{~N}$ coordinate system. The re-projection of the data was completed because the NAD 1983 UTM Zone 17N coordinate system possesses superior accuracy for the region, thus, making any calculations and GIS analyses more accurate. Three-meter resolution digital elevation models (DEM) were obtained from the West Virginia GIS Technical Center to perform hydrological and landform analyses on the two watersheds. The DEM also was projected using the NAD 1983 UTM Zone 17N coordinate system so the surveyed elements would coincide with their site locations within the GIS. 
The data were analyzed spatially to determine the effects of the hillslope attributes on sediment delivery to the stream channel. GIS mapping was used to develop a final land area map with respect to the topographical attributes and the amounts and locations of sediment collected within each of the study watersheds.

\subsection{Sample Processing}

All samples were processed at the U.S. Forest Service's Timber and Watershed Laboratory in Parsons, West Virginia. Each sample was air dried and transferred to a Kraft paper lawn and leaf bag for oven-drying at $100^{\circ} \mathrm{C}$ until a constant weight was obtained. The oven-dried mass of each sample was recorded and then each sample was sorted by hand to separate the "primarily organic" materials from the "primarily mineral" materials. For this part of the study, further processing by silt fence section proceeded only on the "primarily mineral" portion portions of each sample.

The isolated "mostly mineral" materials then were rewetted in a water bath. Materials that floated were assumed to be organic, and thus, were skimmed off from the sample. The water then was poured slowly and carefully from the water bath pan and discarded. The remaining material in the bottom of the water bath pan was transferred to a metal pan and redried at $100^{\circ} \mathrm{C}$. After reweighing the oven-dried material, it was placed in a muffle furnace and combusted at $550^{\circ} \mathrm{C}$ for $2 \mathrm{hr}$. The total mineral weights associated with each section of silt fence each year within each watershed were recorded and entered in a Microsoft ${ }^{\circledR}$ Excel $^{\circledR}$ spreadsheet for further analyses. 


\section{$2.5 \quad$ Road Construction}

Haul road planning in the treatment watershed for this project was headed up and carried out by Monongahela National Forest Engineering Staff. They also oversaw the road construction operations, which were performed by a private contractor. In this project, the haul road was constructed by the logging contractor, which is typical of many forest management operations within the region. The haul road is intended to be permanent but was and is closed to public use during and after construction and use. The road construction crew responsible for road pioneering was rather inexperienced, and this was the first woods road they had ever constructed.

The road construction process began in July of 2002 and was not finished until autumn 2003, leaving the road prism in a disturbed condition, ungraveled, with very few, poorly designed BMPs and water control structures in place over the winter (Bill 2005). The road was re-shaped, excavated to the appropriate grade, and graveled with $10 \mathrm{~cm}$ limestone during the summer of 2003 (Bill 2005). Road graveling occurred throughout the entire summer and into the autumn of 2003 because the contractor used a maximum of only two trucks to transport and tailgate the gravel. Consequently, there were large lengths of the road that were unsurfaced and bare during much of the 2003 growing season. Cross drain culverts and broad-based dips were installed in the summer 2003, improving road drainage substantially (Bill 2005). Cut and fillslopes also were seeded at this time. Vegetation on the fillslope became established relatively rapidly and completely, but the vegetation on the cutbank was unsuccessful for the most part, (Bill 2005; Bold 2007).

The road construction equipment included two large excavators, two John Deere ${ }^{\mathrm{TM}} 650$ bulldozers and a John Deere ${ }^{\mathrm{TM}} 544$ front-end-loader. Figure 2.7 illustrates an example of the disturbance created while constructing the haul road. During road construction, sediment was 
mechanically pushed down the fillslope and into the silt fence. This was the case at several areas approaching the stream crossings. This sediment in the silt fence was a result of steep slopes below the roads and short distances between the roads and the silt fence. In some areas this resulted in massive amounts of sediment reaching the silt fence.

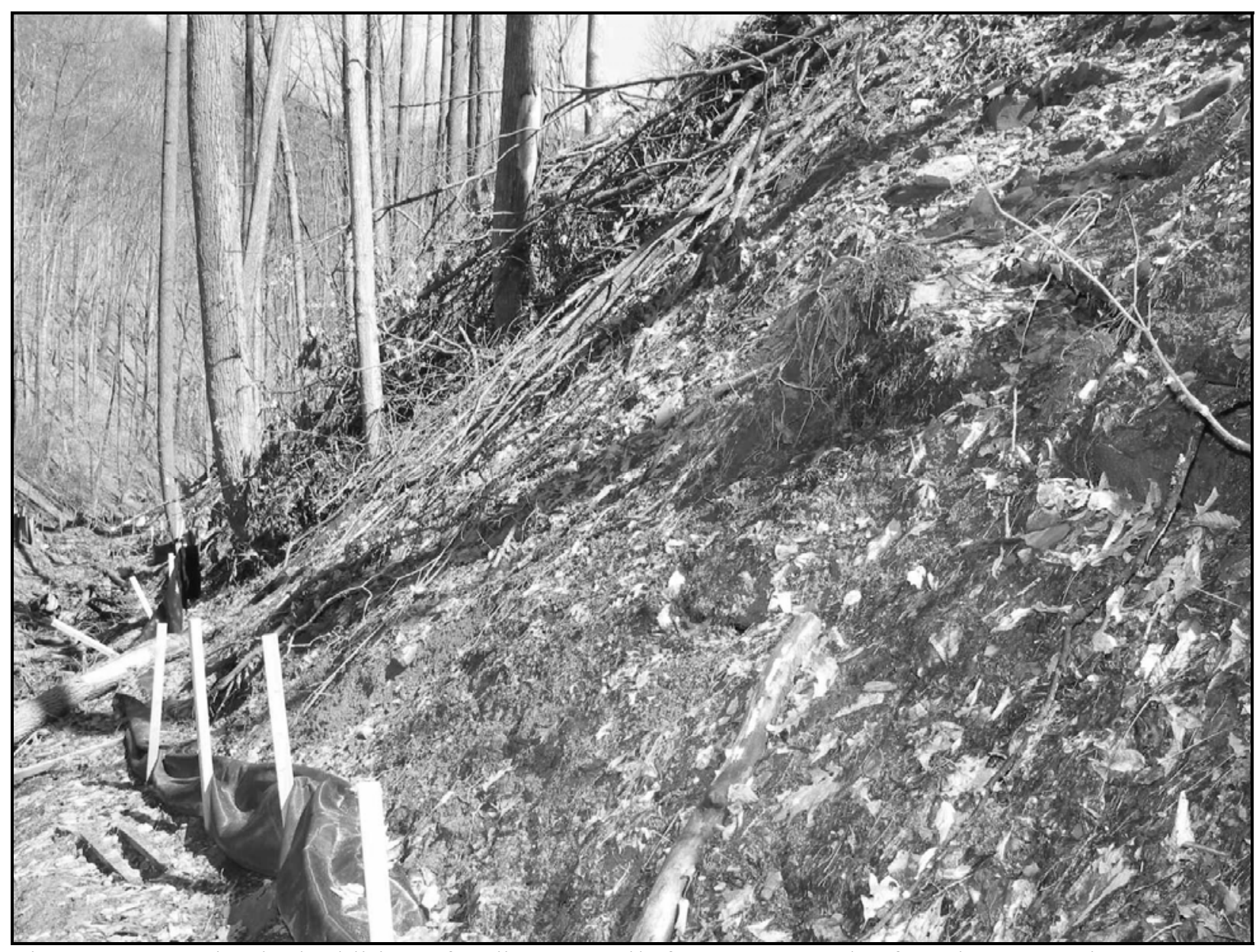

Figure 2.7. Mechanical addition of sediment to silt fence as a result of road construction.

At the first stream crossing, soil material was intentionally pushed into the stream channel to create a pad on which road construction equipment could operate in order to construct the crossing. During this time, stream water was diverted from the channel and pumped 
downstream. After the construction pad was no longer needed the construction pad and associated sediment material was removed from the channel with an excavator. However, all the material purposely pushed into the stream could not be removed using this method.

During road pioneering, there were initially 4 culverted stream crossings in the treatment watershed (Figure 2.8). However, the second culvert was removed and the crossing was eliminated in July 2003. At that time the stream segment upslope (i.e., upstream) of the road that originally contributed to the second cross drain was diverted down a ditch along the road and emptied into the inlet side of the first stream crossing (Figure 2.9). Limestone riprap was placed on the cutbank and in the ditch line at the time this channel was redirected to control erosion. During the relatively short time when the second cross drain culvert was in place, a considerable volume of soil had been eroded from the fillslope, because during road construction the stream segment had been covered up with soil material during the construction of the fillslope and stream discharge had been directed onto this unconsolidated fillslope material. After the culvert was removed, the soil in that area of fillslope was re-smoothed out and hydroseeded and hydromulched with cellulose mulch to stabilize the soil. Each one of the remaining stream crossings had a considerably large amount of fill over the culvert.

All of the cutbank and fillslopes were initially seeded and mulched in late November 2002 for overwintering. Seed consisted of Kentucky 31 fescue (Festuca arundinacea) applied at a rate of 0.0247 tons/hectare $(22 \mathrm{lbs} / \mathrm{ac}$ ), Orchard grass (Dactylis glomerata) applied at 0.01235 tons/hectare $(11 \mathrm{lbs} / \mathrm{ac})$, and Ladino clover (Trifolium repens) at a rate of 0.0022477 tons/hectare (2 lbs/ac). Fertilizer (10-20-20) also was applied at the time of seeding at a rate of 0.56 tons/hectare $(500 \mathrm{lbs} / \mathrm{ac})$. However, vegetation failed to establish due to the late application, which exceeded allowable dates set by the Forest operations contract, and the onset of winter 
conditions. In May 2003, the fillslopes over the cross drain culverts and the cutbanks in the near-crossing areas were reseeded at double the initial rate and chopped hay mulch also was applied. Vegetation establishment was generally good on the fillslopes, but poor on the cutbanks and did not meet the 85 percent germination rate specified in the contract (based on percent coverage on the cutbanks; Bold 2007). Some soil slumping over the first cross drain did occur in the fill over the first culvert about a month after cross drain seeding. Seeding (at initial rates) of the remaining portions of the road prism was completed throughout summer 2003, as sections of the road were completed.

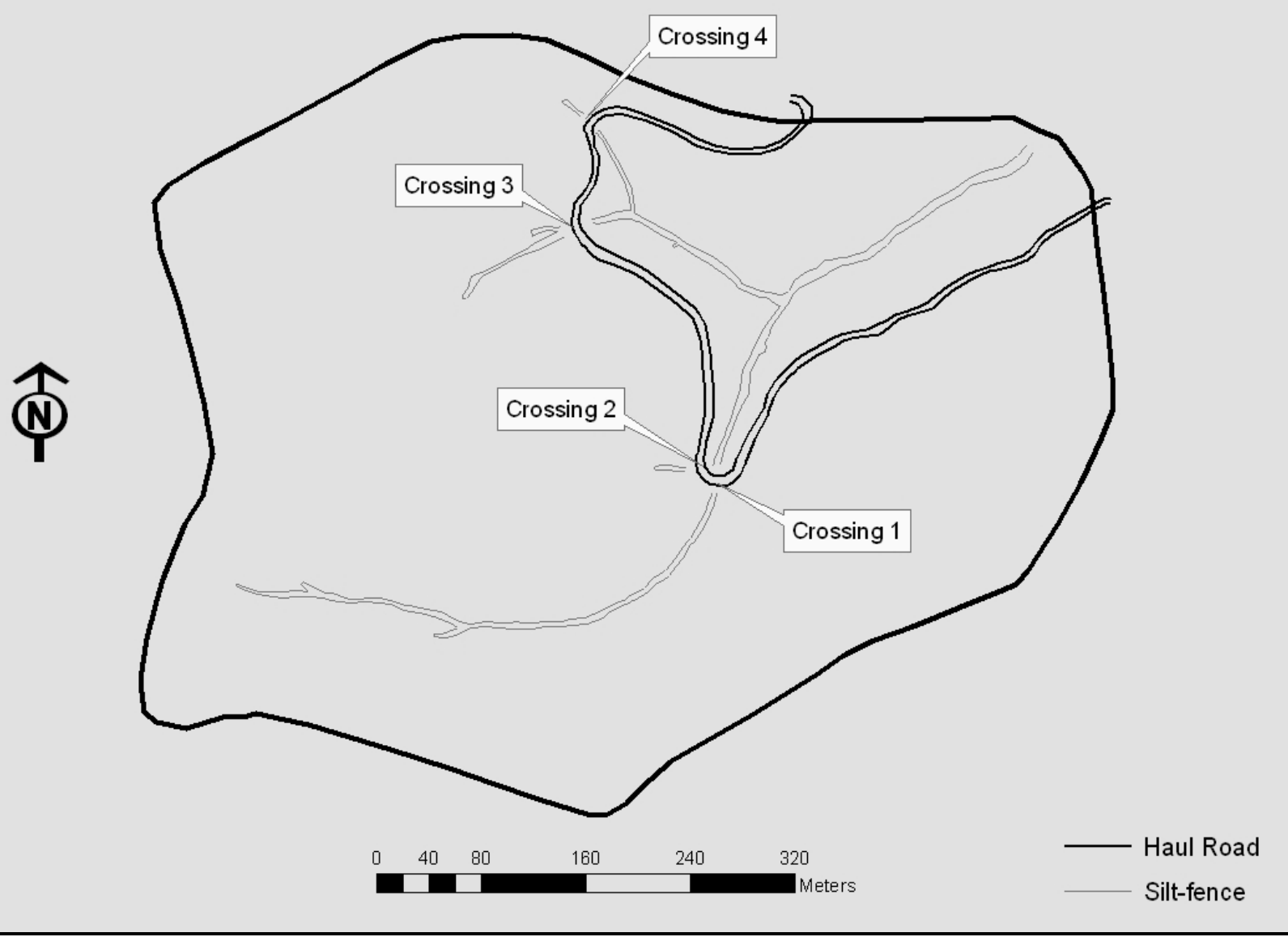

Figure 2.8. Haul road stream crossings in the treatment watershed. 


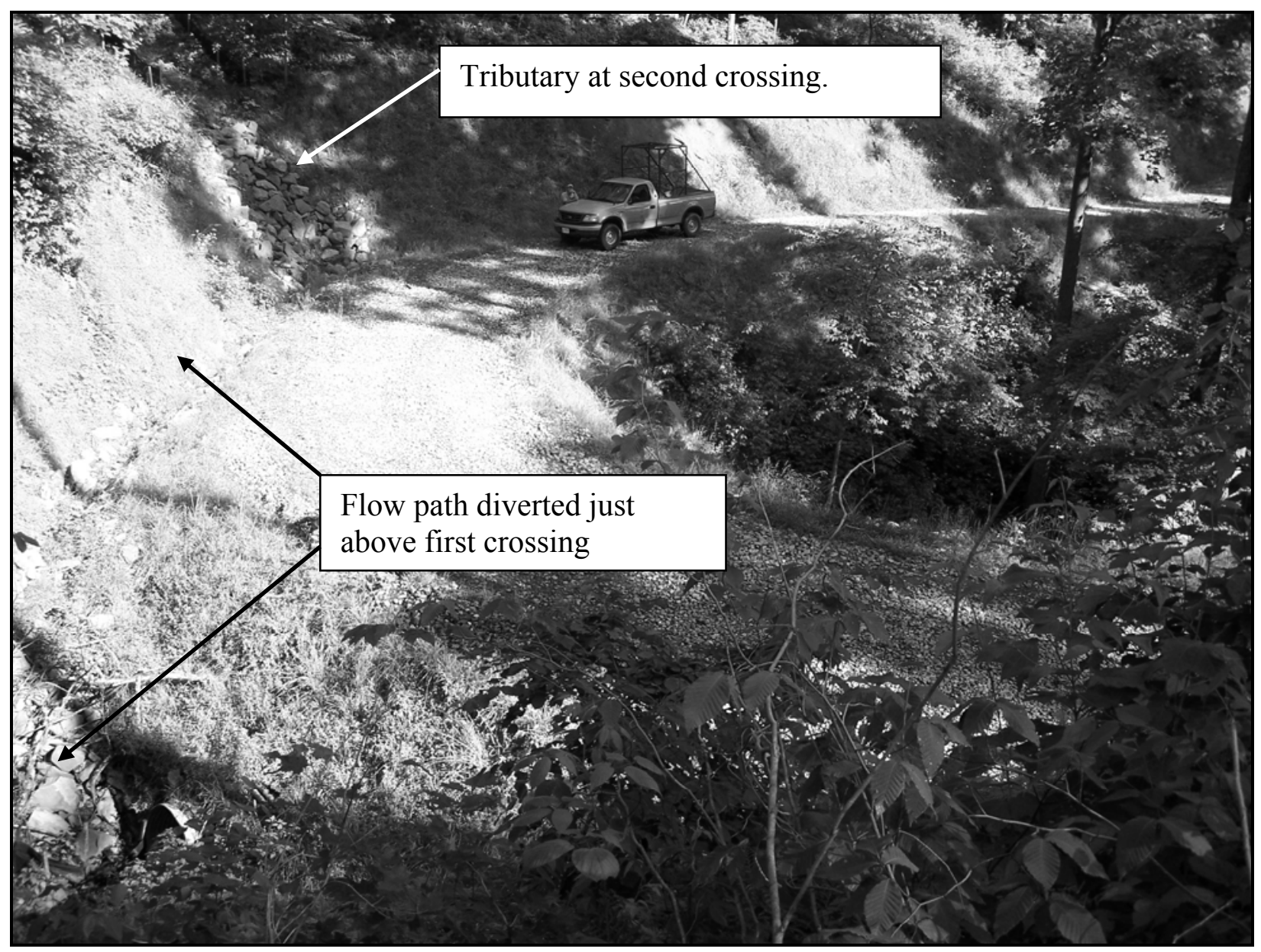

Figure 2.9. Second tributary diverted to flow down rip-rap channel into first stream crossing.

\subsection{Harvesting}

Harvesting operations were performed only in the treatment watershed. Several small harvests (other than the trees removed in the road right-of-way during road construction) were completed through time on the treatment watershed, but only one section was harvested during the period of data covered in this document. This harvest was performed in fall 2003 in a small section near the ridge of the treatment watershed upslope from the fourth stream crossing (Figure 2.10). This regeneration harvest encompassed approximately 2.83 ha (6.99) and involved manual harvesting with chainsaws and rubber tired skidders to transport the logs to the landing. 
A second harvest operation began in May 2005 and ended in September 2005 (Figure 2.10). The portion of this harvest that occurred adjacent to the stream channel and upstream of the first stream crossing was done after sample collection that summer, so it did not influence those data presented in this document. Some of the harvesting on both sides of the road downstream from the first stream crossing was done while sample collection was performed; however, these effects were believed to be minor since very little harvesting actually occurred below the road. Later harvesting also occurred, but was after the period of time covered in this thesis.

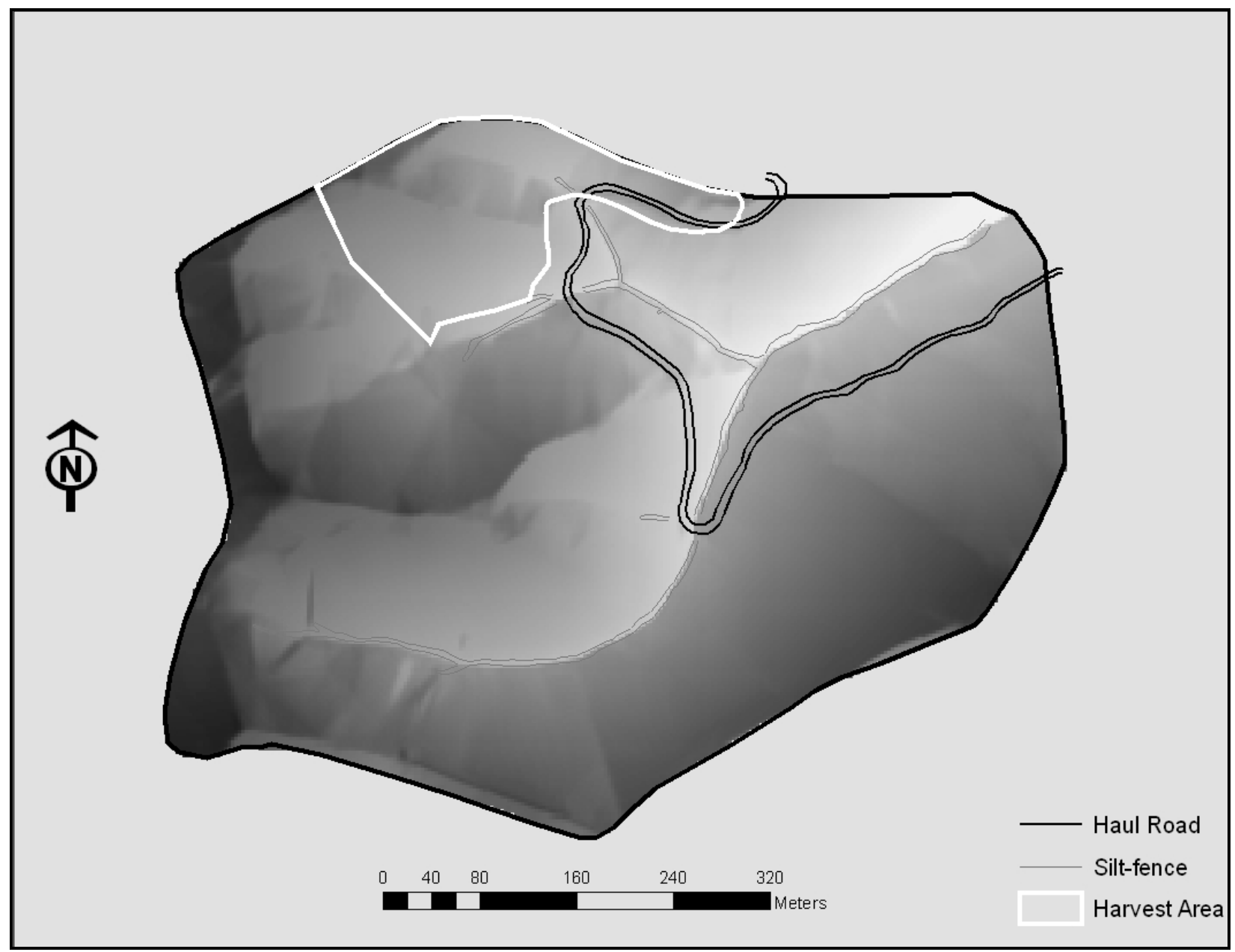

Figure 2.10. Harvest unit within treatment watershed. 


\subsection{Data Analyses}

\subsubsection{Geographic Information System (GIS) Methods}

On-the-ground data for hillside attributes were obtained using the total station, as described in section 2.3.3 (Surveying Topographical and Other Attributes). The total station provided X (easting), Y (northing), and Z (elevation) coordinates for each surveyed point. Shapefiles were created for each surveyed feature using ArcCatalog ${ }^{\circledR}$. Shapefiles were then merged into one shapefile for each feature type and year (e.g., tree falls surveyed in 2004, new tree falls surveyed in 2005 , etc.). The shapefiles for the silt fence, posts, roads, animal trails, soil series, cut-and-fill slopes, areas of bare soil, tree falls and others attributes, were obtained from the USDA Forest Service Northern Research Station office in Parsons, West Virginia.

Three-meter digital elevation models (DEMs) of the two watersheds (Figure 2.11) were obtained from the West Virginia GIS Technical Center to perform hydrological and landform analyses. A DEM is a digital raster consisting of square cells, which in this case measure 3-m by 3-m for a total of a $9 \mathrm{~m}^{2}$ area and have an elevation value appended to each cell. The DEMs also were projected using the NAD 1983 UTM Zone 17N coordinate system so the surveyed elements would coincide with their site location within the GIS. 


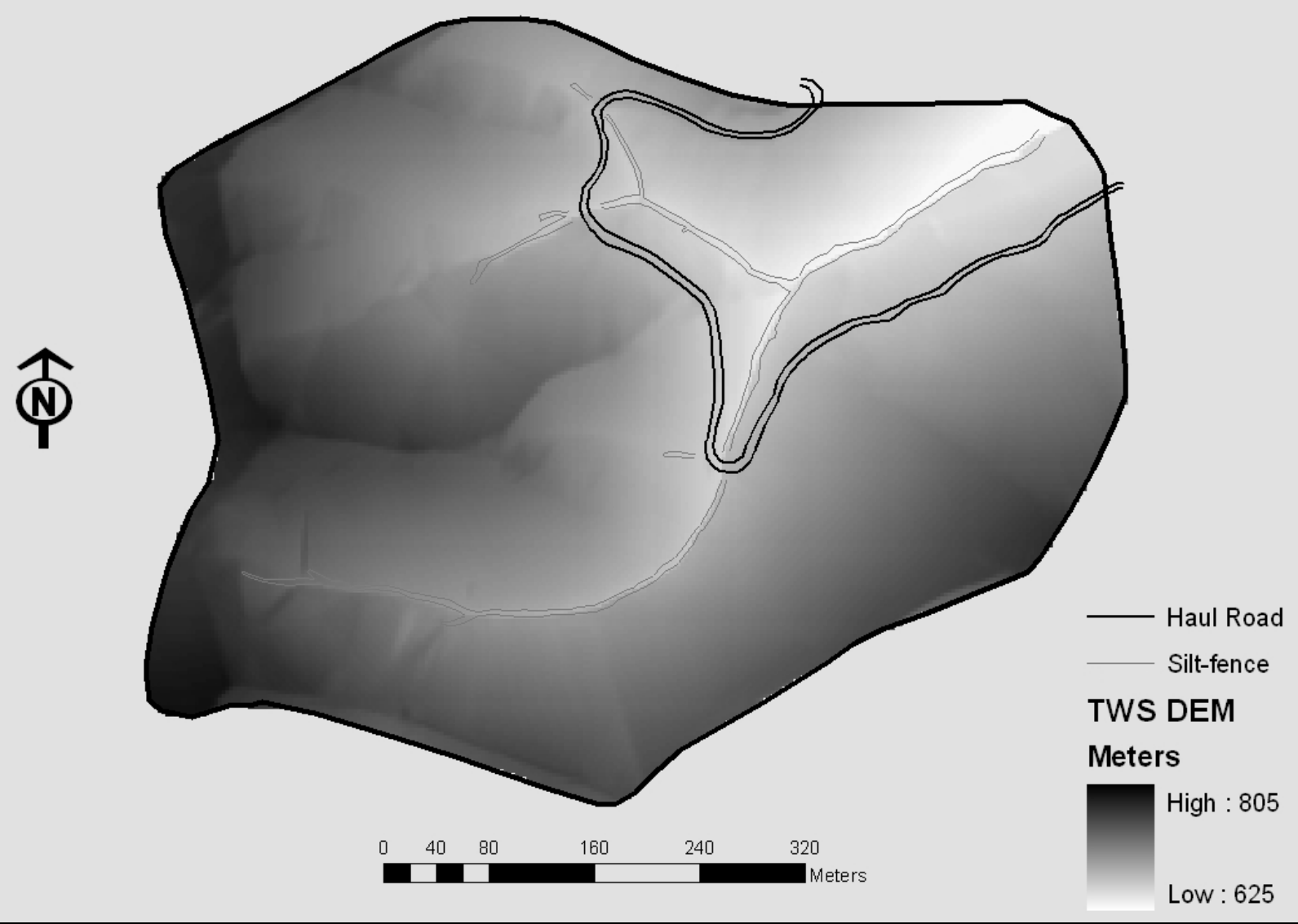

Figure 2.11. Treatment watershed digital elevation map (DEM) at $3 \mathrm{~m}$ resolution.

In order to use the DEM for hydrologic analyses, sinks had to be filled to make the DEM surface continuous and allow the surface flow hydrology functions within the GIS to operate properly. Sinks are cells without values that disrupt surface flow hydrology operations within a GIS. These sinks are a result of errors during the DEM creation process. The first step to the spatial analysis was to clip the original respective DEMs to the control and treatment watershed boundaries. These DEM clips then were copied to separate $\operatorname{ArcMap}^{\circledR}$ data frames, one for each year of the study period. These data frames contained the feature shapefiles associated with each silt fence section and mineral weights collected from each silt fence section that were appended 
manually to the attribute table for each watershed. Various raster grids were created from the DEMs using the Spatial Analyst extension. The initial raster grids created were Slope, both in percent and degrees, and Aspect. The Aspect grid contains 9 separate categories: Flat, North, Northeast, East, Southeast, South, Southwest, West, and Northwest. The DEMs also were used to develop 2 hydrological rasters, Flow Direction (FlowDir) and Flow Accumulation (FlowAccum). The FlowDir raster was created first and is essentially based upon the aspect of an area. By using the aspect of each cell within the DEM, the GIS analyzes each cell to determine the direction surface water would flow out of each cell. Essentially each cell is given a value to indicate the direction of flow out of each cell. FlowAccum builds upon this by accumulating this flow from cell to cell and displaying it in a raster grid. By using the data from the FlowDir raster to determine direction of flow and the elevation data from the DEM to determine which cells flow into one another, the FlowAccum raster is created -- each cell is given a value based upon the total number of cells that would cumulatively flow into it from the entire upstream drainage area extent.

Creating these hydrologic grids allows the subsequent use of several interactive hydrologic tools, including the raindrop tool. The raindrop tool can identify the flow path from any selected point within a watershed to the stream below. This tool was used to determine the flow path from each topographical feature of interest to the specific silt fence section it contributed to down slope along the stream (Figure 2.12). However, these flow paths were not ground-truthed, so there may be some error in later modeling results that are attributable to defining delivery by this technique. This is particularly the case since the cell size of the DEMs was fairly large $(3 \mathrm{~m} \times 3 \mathrm{~m})$ relative to the widths size of concentrated flow paths on the ground that may be the conduits by which sediment is delivered to streams. Additionally, the raindrop 
tool bases these flow paths off topography alone and does not account for surface cover or roughness. However, in the case of this study the terrain is so steep it is likely surface cover and/or roughness will not alter flow paths dramatically.

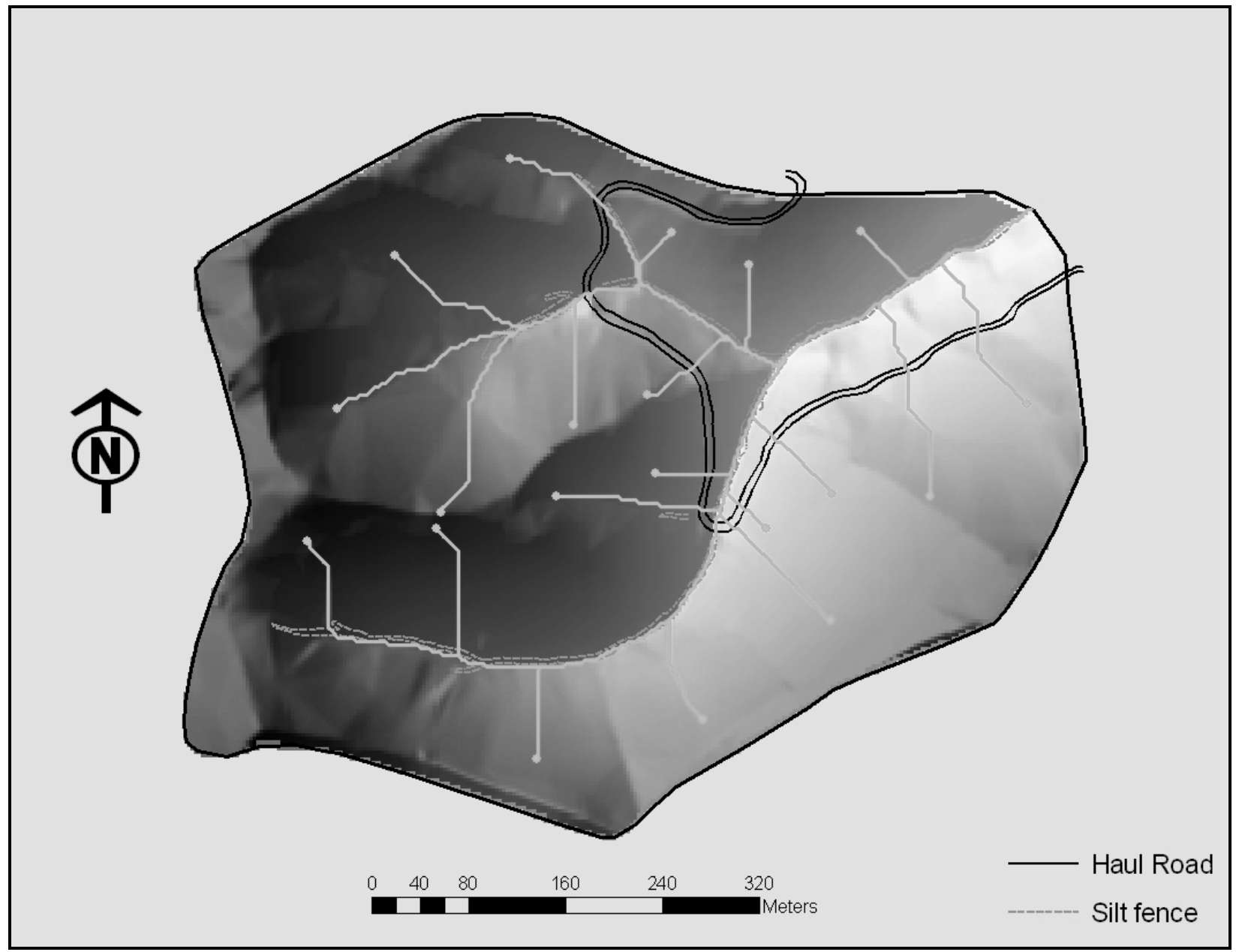

Figure 2.12. Examples of using the raindrop tool flow path identifier for delivering sediment to the silt fence.

The Spatial Analyst distance tool was used to calculate several distance measurement rasters. Each cell of a distance grid contains the straight-line horizontal distance value from the selected feature of interest to another point on the ground. One distance raster was the distancefrom-the-silt fence (Figure 2.13). The distance-from-silt fence grid then was used to obtain 
several specific horizontal distance measurements (note, the distance classes shown in Figure 2.13 are basically insignificant as this grid was used to identify the specific distance to areas of interest and not simply the distance class). This was accomplished by using the identify tool at each specific point of interest. These measurements included the minimum distances to contributing bare soil areas, tree falls, animal trails, slope breaks, water-driven erosion features (WDEFs), fillslope, and road surface edge to the respective silt fence section to which that attribute would deliver sediment (as modeled using the raindrop tool described above) for each year of the study period. WDEFs include springs, seeps, slips, washes, channel extensions and other features that deliver sediment as flowing water. These distance values were all recorded in meters as the minimum distance to the topographical feature to two decimal places. These distance values were then manually appended to the attribute table of the silt fence shapefile for each appropriate silt fence. 


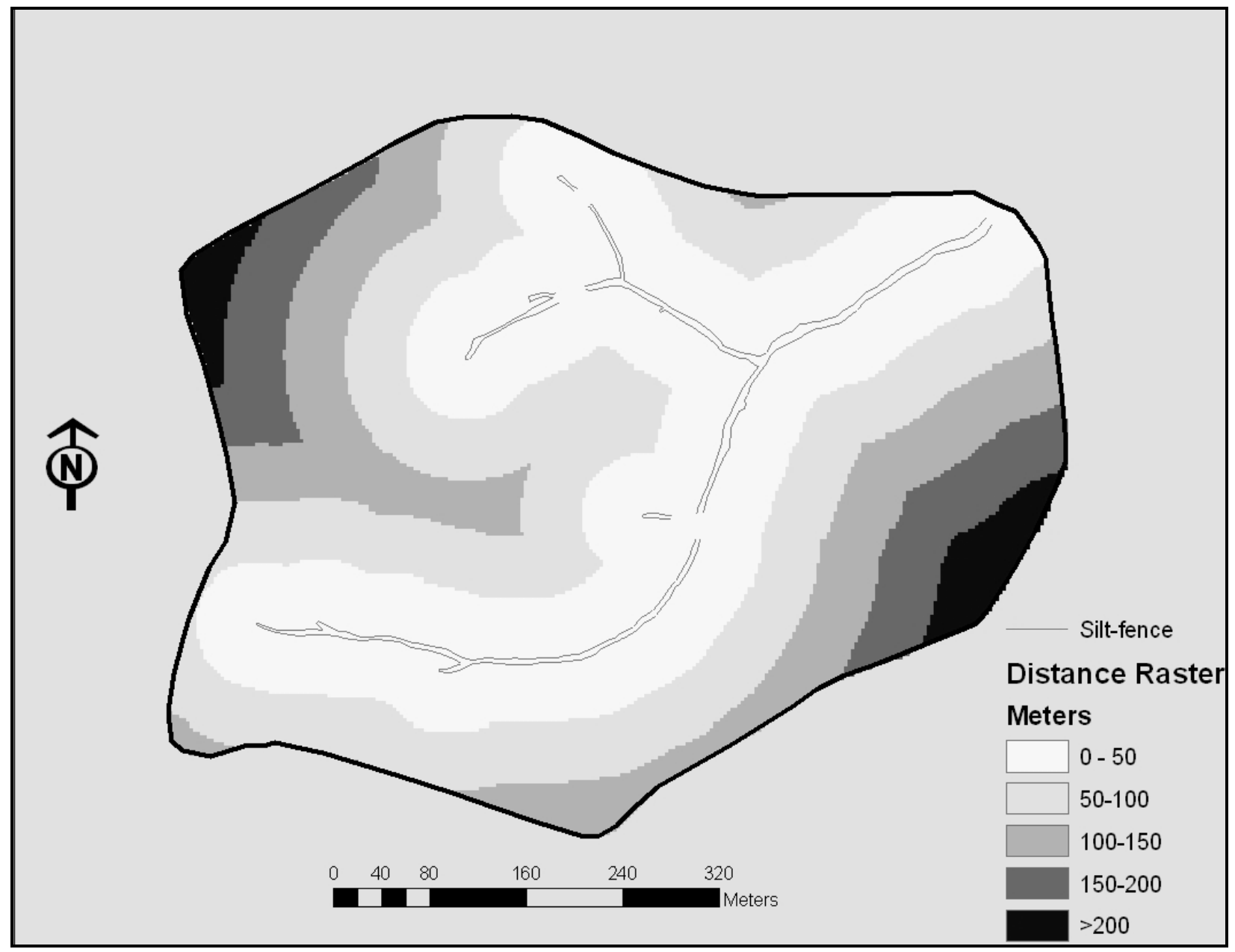

Figure 2.13. Raster grid for distance from the silt fence for the treatment watershed.

Analyses were also performed on an area basis by dividing the two watersheds into contributing areas: 9 for the treatment watershed (Figure 2.14) and 10 for the control watershed (Figure 2.15). The contributing areas were created using Spatial Analyst and then modified slightly to adjust their boundaries to coincide with end points of silt fence sections (i.e., the numbered posts). These modifications ensured that each silt fence section and its related data were assigned to a single contributing area. 


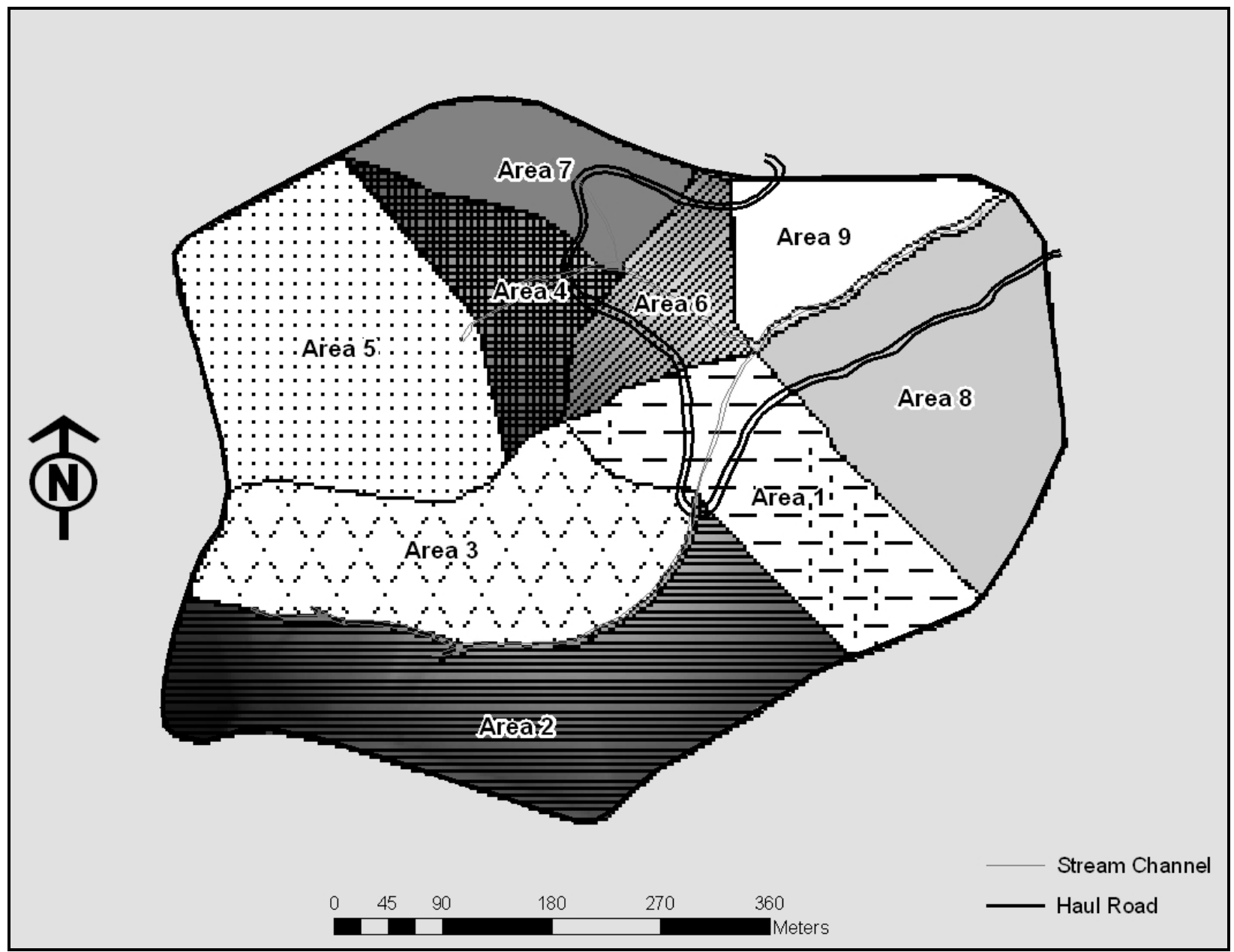

Figure 2.14. Treatment watershed contributing areas. 


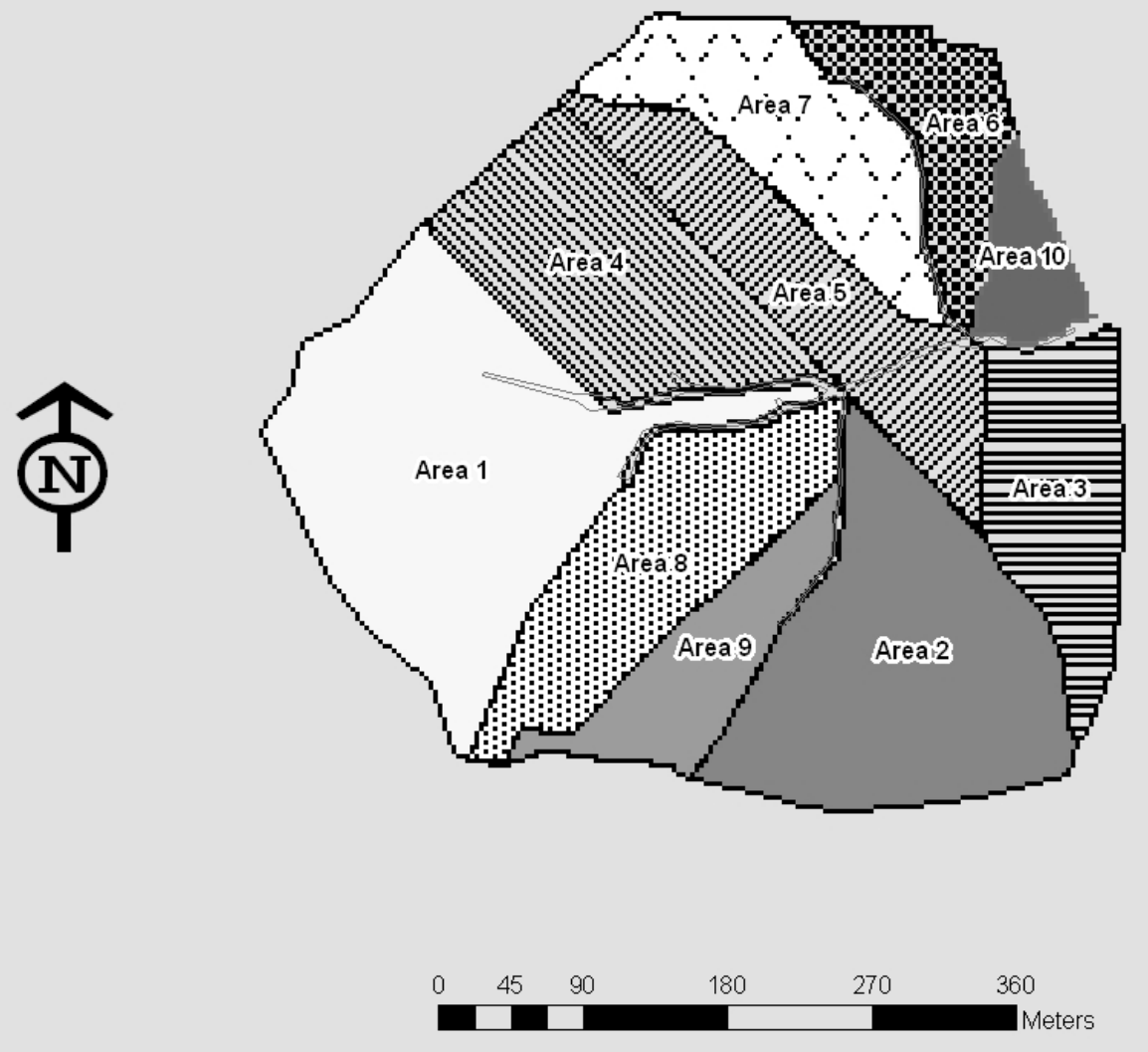

Stream Channel

Figure 2.15. Control watershed contributing areas.

Another analysis which was performed using the GIS was the comparison of field measurements of soil delivery from the two watersheds to those estimated from the RUSLE model. Data from the DEMs, soils information, and cover and management practices data, were input into RUSLE to create estimates of soil loss per acre for both study watersheds. The GIS was used to implement an Application Markup Language script (ESRI Press 1995), developed by the U.S. Dept. of the Interior Bureau of Land Management (BLM) (http://www.blm.gov/nstc/ecosysmod/rusle.html), to create raster grids illustrating the slope length and steepness factors of the study watersheds (the L and S factors for RUSLE). These 
grids were created by the script based on data from the input DEM. The other variables of the soil loss equations, $\mathrm{R}, \mathrm{K}, \mathrm{C}$, and $\mathrm{P}$, were determined from either on-site evaluation or knowledge of the study watersheds. The value for the $\mathrm{R}$ variable was obtained from Purdue University (http://cobweb.ecn.purdue.edu/ abe526/resources1/erosiondocs/usleapp.html), the values for the K variable were obtained from University of Guelph, Ontario, Canada (http://www.uoguelph.ca/geography/research/geog4480_w2004/Group02/Obj_1.html), and the C and $\mathrm{P}$ variables were combined and assigned a value of 0.011 based upon the study by Ozhan et al. (2005). Input raster grids for the study watersheds were created within GIS, which contained values for each respective variable of the RUSLE. The input raster grids were then combined using the RUSLE script developed by BLM, to create site-specific soil loss estimates for the study watersheds.

\subsubsection{Statistical Analysis Methods}

The statistical analyses were completed using several software applications, including the

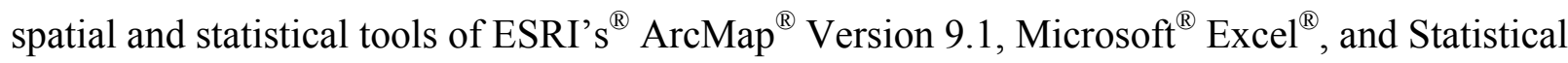
Analysis Systems $\left(\mathrm{SAS}^{\circledR}\right)$ Version 9.1 (2004). Microsoft ${ }^{\circledR}$ Excel $^{\circledR}$ was used for some simple calculations and graphing procedures, such as averages, sums, and graphs depicting sediment expressed over the study period and on a per-unit-area basis, and to organize the data and create a formatted dataset compatible with SAS ${ }^{\circledR}$. Microsoft ${ }^{\circledR}$ Excel $^{\circledR}$ also was used to identify trends in the data that might have influenced results, such as identification of silt fence sections with the consistently highest and lowest masses of sediment over the study period. The complete dataset included the mineral material weights collected from the silt fence, data about the surveyed topographical features, and data derived from the raster grids created from the DEMs. The 
dataset for the independent variables included minimum distances to features including areas of bare soil, tree falls and their related soil (root wads), animal trails, slope breaks, the road, fillslopes, WDEFs, the contributing slope in degrees, the total contributing area of natural bare soil, the total contributing area of tree fall related soil, the majority contributing soil type for each silt fence section, and the year. After the complete data set was organized and formatted, it was imported into $\mathrm{SAS}^{\circledR}$ (2004) to obtain means, frequencies, maximums, minimums, standard deviations and other statistics describing the variables within the dataset.

SAS $^{\circledR}$ (2004) was used to analyze whether the independent variables listed previously explained a significant amount of the variability in the mineral mass collected in the silt fence (dependent variable). The model was evaluated on a per-silt fence-section basis for each watershed as well as evaluated on a per-unit-area basis with respect to the derived contributing areas, described previously in section 2.7.1. The data were analyzed on a per-silt fence-section basis to identify specific attributes associated with small areas that contribute to significant increases in hill-slope soil movement. The contributing area analysis then was performed to draw more specific conclusions on a per-unit-area basis about what topographical attributes may contribute to hill-slope soil movement and to provide per-unit-area estimates for comparison to other studies.

The SAS ${ }^{\circledR}$ Generalized Linear Model (GLM) procedure was used to perform analysis of variance tests on the variables using the model shown in equation 2 for the treatment watershed. The model was modified to exclude the distance to road and distance to fillslope variables for the control watershed analysis by silt fence section. Not all silt fence sections contained all types of hillside attributes; for example, tree falls were not present upslope from every fence section. For some attributes, such as WDEFs, missing data are much more prevalent than occurrences. 
Because the GLM procedure excludes data lines with missing observations during analyses, where there were no occurrences of a variable for a single section of silt fence, values of either 100 or 500 were assigned to the variable. Thus, all the observations could be used and yet the missing values could be identified in the results. Including the observations with no occurrences also allowed for the identification of effects resulting from the presence of topographical features compared to where they were absent.

$$
\begin{aligned}
& M W T_{\text {abcdefghihkl }}=\mu+Y R_{a}+S C_{b}+W T C_{c}+D W T_{d}+B S A_{e}+D B S_{f}+ \\
& D F S_{g}+D R D_{h}+D S B_{i}+D A T_{j}+D W D E F_{k}+\varepsilon_{\text {abcdefghijkl }}
\end{aligned}
$$

Where: $M W T=$ Mineral weight

$$
\begin{aligned}
& Y R_{a}=\text { Year }(1,2,3,4) \\
& S C_{b}=\text { Slope Class }(1,2,3,4) \\
& W T C_{c}=\text { Tree fall Soil Area Class }(1,2,3,4,5,6) \\
& D W T_{d}=\text { Minimum Distance to Tree falls }(1,2,3,4,5,6) \\
& B S A_{e}=\text { Bare Soil Area Class }(1,2,3,4,5) \\
& D B S_{f}=\text { Minimum Distance to Bare Soil }(1,2,3,4,5,6) \\
& D F S_{g}=\text { Minimum Distance to Fill-slope }(1,2,3,4,5,6) \\
& D R D_{h}=\text { Minimum Distance to Roads }(1,2,3,4,5) \\
& D S B_{i}=\text { Minimum Distance to Slope-breaks }(1,2,3,4,5,6) \\
& D A T_{j}=\text { Minimum Distance to Animal Trails }(1,2,3,4,5) \\
& D W D E F_{k}=\text { Minimum Distance to WDEFs }(1,2,3,4,5,6) \\
& \varepsilon=\text { error term }
\end{aligned}
$$

The numbers in parentheses following each variable are the class designations in each, with the actual values assigned to each class designation given in the lists below for the by silt fence analysis and contributing area (per unit area) analysis.

For the silt fence section analysis:

Mineral Weight $=$ grams of sediment

Year: $1=2002,2=2003,3=2004,4=2005$

Slope Class (degrees): $1=20,2=25,3=30,4=35$

Tree fall Soil Area Class (square meters): $1=3,2=5,3=8,4=13,5=40,6=100$ (No occurrence)

Minimum Distance to Tree Falls (meters): $1=1,2=4,3=9,4=25,5=30,6=100$ (No occurrence)

Bare Soil Area Class (square meters): $1=4,2=15,3=50,4=60,5=100$ (No occurrence) 
Minimum Distance to Bare Soil (meters): 1=0, 2=1, 3=2, 4=8, 5=20, $6=100$ (No occurrence)

Minimum Distance to Fill-slope (meters): $1=10,2=25,3=45,4=65,5=105,6=500$ (No occurrence)

Minimum Distance to Roads (meters): $1=15,2=30,3=50,4=70,5=500$ (No occurrence) Minimum Distance to Slope-breaks (meters): $1=2,2=6,3=8,4=11.5,5=15,6=100$ (No occurrence)

Minimum Distance to Animal Trails (meters): $1=0.5,2=6,3=14,4=30,5=100$ (No occurrence)

Minimum Distance to WDEFs (meters): $1=0.5,2=3,3=15,4=40,5=100,6=500$ (No occurrence)

For contributing area analysis:

Average Mineral Weight Per-acre=average grams of mineral weight per-acre by contributing area.

Average Slope Class: $1=20,2=25,3=30$

Average Tree fall Soil Area Class: $1=3,2=7,3=12,4=18,5=24$

Average Minimum Distance to Tree Falls: $1=6.5,2=9,3=11.7,4=12.5,5=30$

Average Bare Soil Area Class: 1=10, 2=20, 3=50, 4=60

Average Minimum Distance to Bare Soil: $1=1.5,2=2.5,3=6,4=7$

Average Minimum Distance to Fill-slope: $1=15,2=22.5,3=48,4=55,5=86$

Average Minimum Distance to Roads: $1=8,2=21,3=30,4=60,5=100$

Average Minimum Distance to Slope-breaks: $1=2,2=5,3=6.5,4=8.4,5=9$

Average Minimum Distance to Animal Trails: $1=3,2=8,3=10,4=14.5,5=100$

Average Minimum Distance to WDEFs: $1=2.5,2=5.5,3=15,4=25.5,5=40,6=100$

Contributing Area: 1, 2, 3, 4, 5, 6, 7, 8, 9, 10

For the analysis by silt fence section, the raw data were used as the independent variables and the total mineral mass for each section was used as the dependent variable each year.

Statistically significant variables $(\mathrm{P}=0.10)$ obtained from the section-by-section analysis of variance were identified for the control and treatment watersheds. Pairwise comparisons of the least square (LS) means were made between classes using Tukey's adjustment for unequal cell sizes (SAS 2004) to identify which classes were statistically different from one another for each of the significant variables.

For the analysis of variance for the contributing areas, a single average was calculated for the each independent variable in each contributing area each year. The class for each variable 
then was assigned based on the average value for that contributing area. Due to the low number of degrees of freedom available from using average data, the analysis of variance had to be run for one independent variable at a time (as opposed to all variables simultaneously used in the section-by-section analyses). The first test, which employed contributing area as the independent variable, showed there were very large, significant differences among them (i.e., there were large differences in the average amount of sediment delivered to the silt fence from each contributing area). Because the differences among contributing areas were so substantial, the contributing areas were grouped into two different categories (high and low sediment delivery) to provide a reasonable number of areas in each group and increase sample sizes. These groupings were determined from LS mean pairwise comparison tests, which identified the groupings that were different from one another. Subsequent analysis of variance tests using each independent variable individually were performed by high or low sediment group.

In each instance in both analyses where the slope and a distance variable were found to be significant contributing factors, the model was re-run to test the significance of the interaction between the slope and distance variables to attempt to identify a correlation between slope and distance with regard to sediment delivery.

For each of the independent variables identified as significant $(\mathrm{P}=0.10)$ within each sediment grouping, pairwise comparisons were made on the Tukey's adjusted LS means. These pairwise comparisons were based on averages (as described above). 


\section{CHAPTER 3 - RESULTS}

\subsection{Sediment Delivery Summary}

During the study period (2002-2005), 6.17 metric tons of mineral material were delivered to the silt fence within the treatment watershed. During the same period, the control watershed produced 0.56 metric tons of mineral material (Fig. 3.1). Average annual sediment production for the four years was significantly greater in the treatment watershed than in the control watershed (1.54 metric tons vs. 0.14 metric tons; $\mathrm{P}=0.019)$.

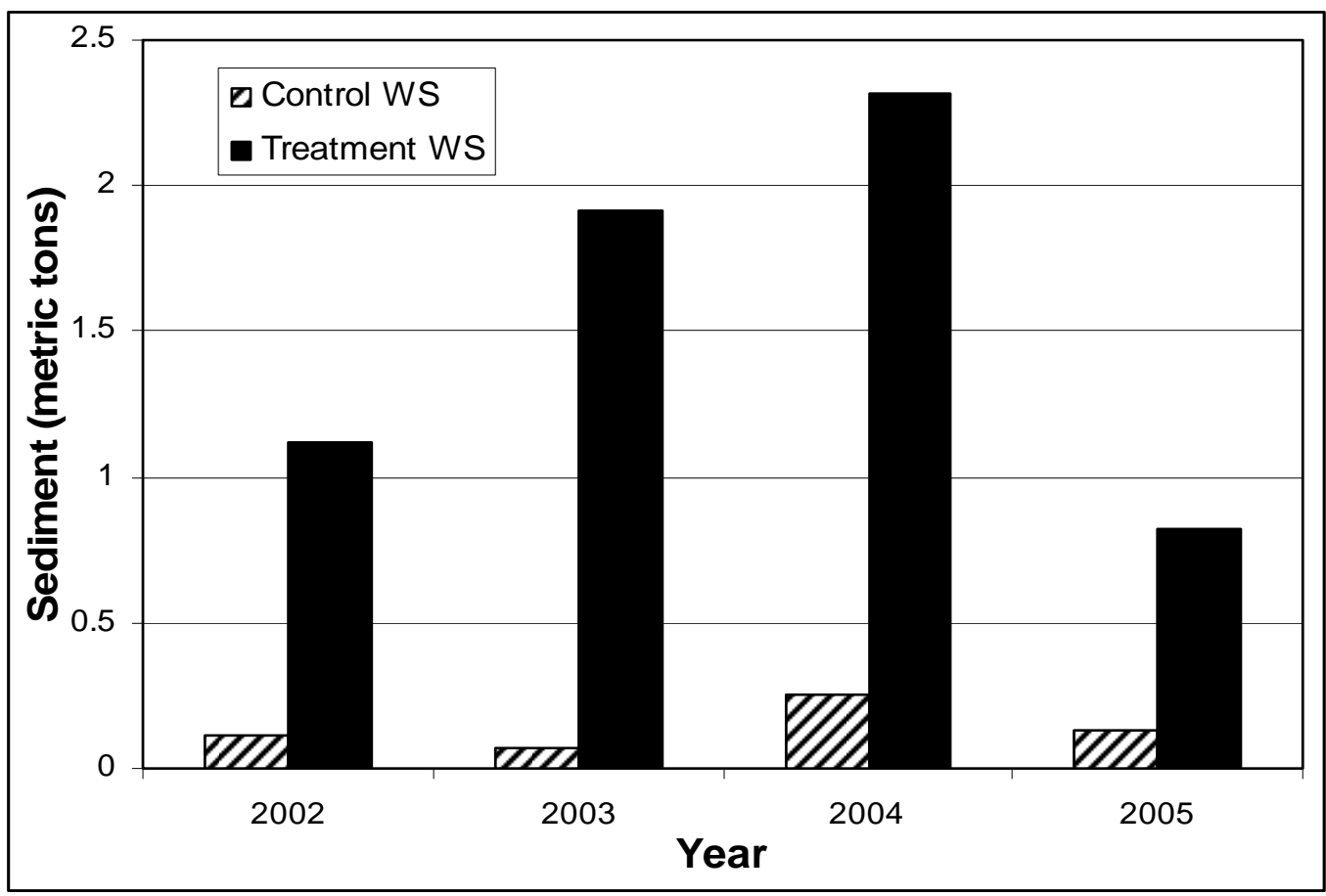

Figure 3.1. Total metric tons of sediment delivered to the silt fences each year.

Part of this difference in sediment delivery between the two watersheds can be attributed to their different areas and the difference in stream length within each watershed. The treatment watershed is 11.21 ha greater in area and the stream length is $423 \mathrm{~m}$ longer than in the control 
watershed. However, when analyzed on an area basis, the treatment watershed still produced significantly more $(\mathrm{P}=0.016)$ sediment on average than the control watershed $(0.0198$ metric tons ha ${ }^{-1}$ vs.0.0028 metric tons ha ${ }^{-1}$, respectively) (Fig. 3.2). Similarly, on a stream-length basis the treatment watershed produced approximately 7.5 times more sediment $\left(0.0012\right.$ metric tons $\mathrm{m}^{-}$ ${ }^{1}$ vs. 0.0002 metric tons $\mathrm{m}^{-1}$ ) on average than did the control watershed (Fig. 3.3).

Total sediment delivery in the treatment watershed increased approximately $81 \%$ from 2002 to 2003 , and another $21 \%$ from 2003 to 2004 (Fig. 3.1). It then decreased 182\% from 2004 to 2005 . By comparison, total watershed sediment delivery in the control watershed decreased approximately $62 \%$ from 2002 to 2003 , then increased $381 \%$ from 2003 to 2004 , and then decreased 50\% from 2004 to 2005 (Fig. 3.1).

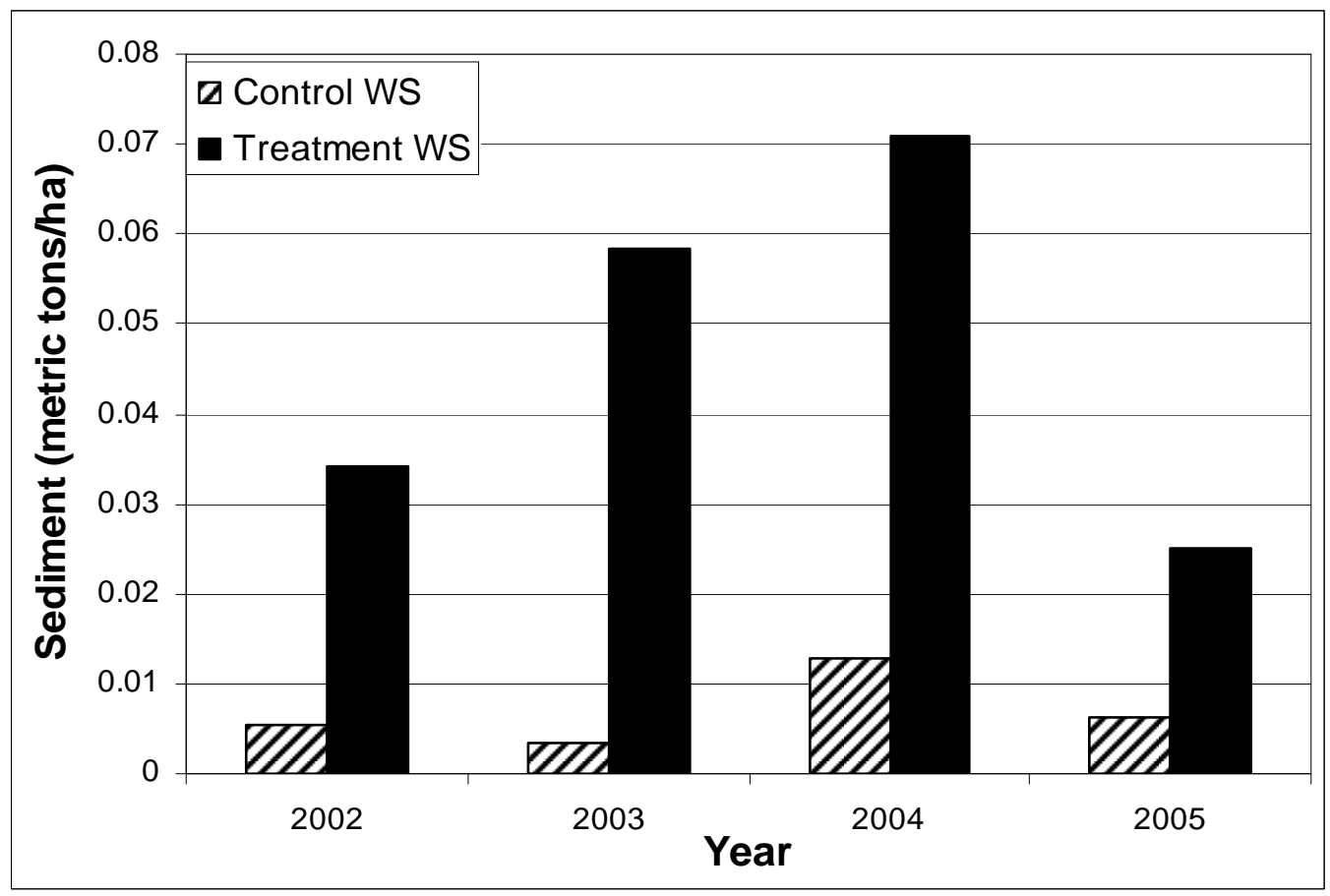

Figure 3.2. Sediment delivery expressed on an area basis for each watershed each year. 


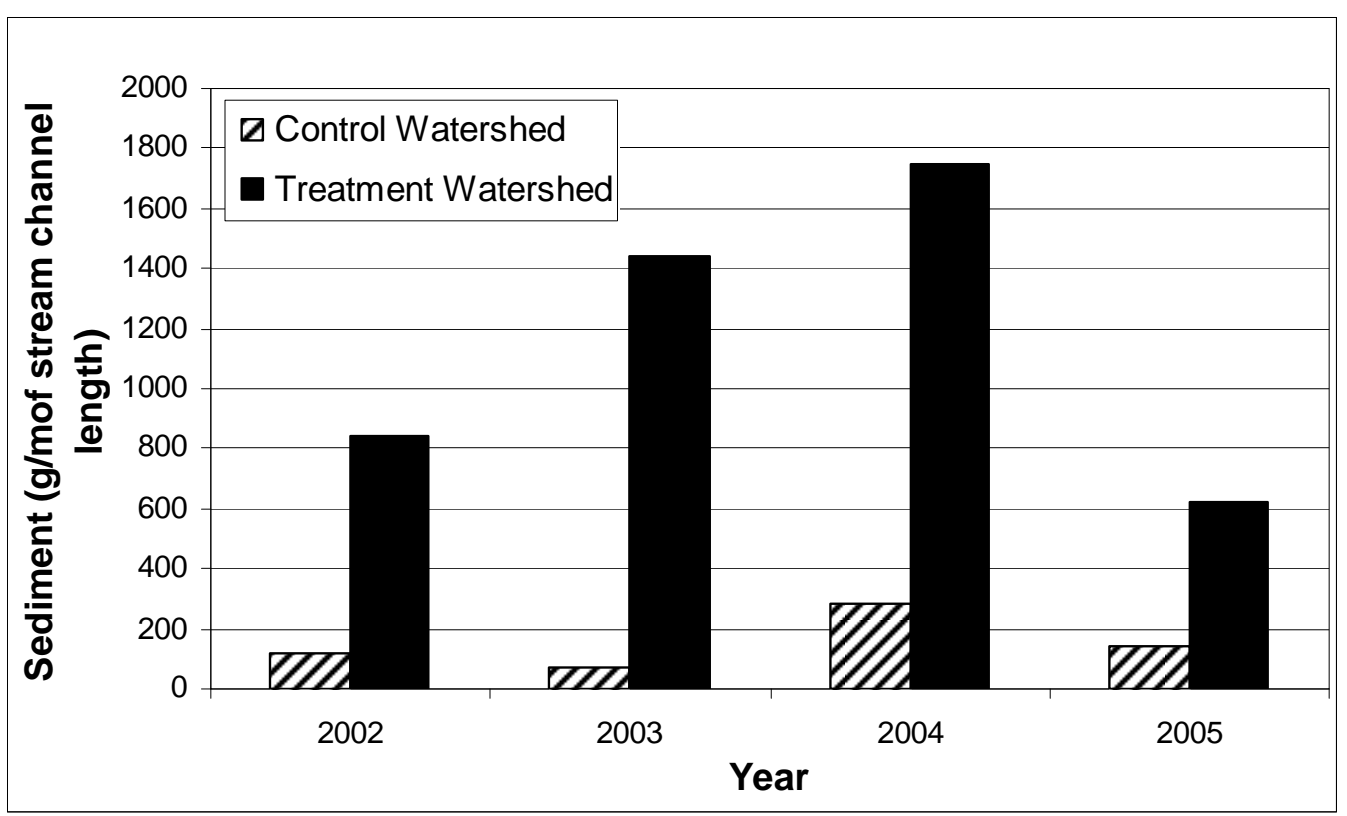

Figure 3.3. Sediment delivery expressed on stream-length basis for each watershed each year.

Recall that the data obtained from samples collected in summer 2003 represent sediment delivered during the time from when road pioneering began in the 2002 through the period when road improvements (moving toward road completion) began in summer 2003. Sediment collected in silt fence sections that were within 30.48 horizontal meters (100 feet) of the road surface in 2003 accounted for 73 percent of the mineral material that year (Fig. 3.4). Fifty-five sections, or about one-third of the total number of sections in the treatment watershed, were completely or partially within $30.48 \mathrm{~m}$ (100-feet) of the road surface. These particular silt fence sections were located almost exclusively just downstream from the stream crossings. These high loads of delivered sediment were attributable to side cast material that was mechanically pushed downslope into the silt fence during road construction to create the fillslope, and then subsequently from material eroded from the fillslope until it became more stabilized following 
seeding. Smaller, but still substantial amounts also were transported to the silt fence from two cross drainage features on the road that also were located within $30.48 \mathrm{~m}$ (100 ft.) of the stream. The percentage of mineral material captured in these sections declined each year as the road surface and associated cut banks and especially fillslopes stabilized (Fig. 3.4). In 2004, sediment collected from these same sections accounted for only $43 \%$ of the total sediment material and only $26 \%$ of the total in 2005 . The disturbed areas stabilized enough by 2005 that the amount of sediment material collected from these silt fence sections ( 0.22 metric tons) fell below those that were present prior to road construction in 2002 ( 0.35 metric tons).

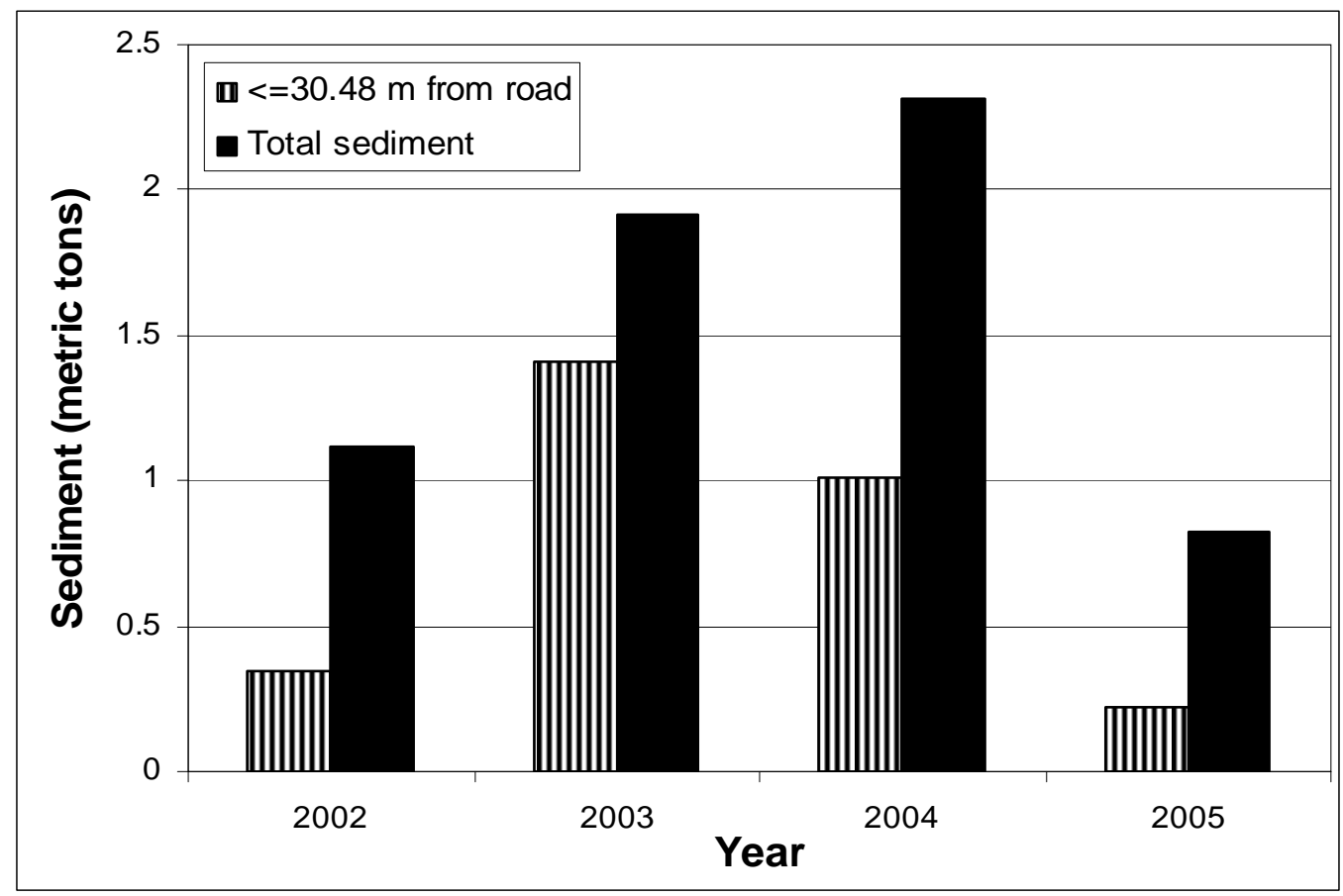

Figure 3.4. Sediment collected from silt fence sections located within 30.48 horizontal meters (100 feet) of the road surface in the treatment watershed.

Analyses of high and low yielding sections were made using data from the sections of silt fence that consistently captured the highest 25 or lowest 25 masses of sediment over the four 
years of study out of all the silt fence sections. Throughout the study period, 96 percent of the silt fence sections in both watersheds that consistently collected the highest amounts of mineral material were adjacent to slopes that were steeper than 25 degrees (43\%). Additionally, greater than $90 \%$ of the 25 consistently lowest yielding silt fence sections were adjacent to areas with slopes less than 25 degrees ( $43 \%$ ). These results related to contributing slopes were based upon an initial slope value identified using GIS for each silt fence section. All of the top 25 yielding silt fence sections throughout the study period were within 10 horizontal meters of bare soil areas and/or disturbed soils associated with tree falls and/or slope-breaks.

Analyses showed none of the soil associations had a statistically significant effect on sediment delivery in either watershed. However, there was a direct relationship (positive correlation) between the amount of sediment delivered to the silt fence and the area in each watershed comprised of each soil association. That is, not surprisingly the soil association comprising the most area contributed the greatest amount of sediment in each watershed and vice versa.

\subsection{Section-Based Analyses}

The section-based analysis linked annual sediment masses collected from the individual silt fence sections to hillside features associated with the section to determine which of those features were important for explaining sediment delivery. There was a large variability in the amount of sediment delivered among silt fence sections (Table 3.1). In all years for both watersheds, the standard deviations were greater than the raw means. This is not surprising since previous analyses of fence sections with high and low masses of sediment were influenced by 
factors such as slope, distance from the road or fillslope, the presence of cross drains, etc., that varied spatially within the watersheds.

Table 3.1. Mean mineral weight (g) of soil captured in the silt fence each year in the treatment and control watersheds.

\begin{tabular}{crccc}
\hline & \multicolumn{2}{c}{ Treatment Watershed } & \multicolumn{2}{c}{ Control Watershed } \\
\hline Year & \multicolumn{1}{c}{ Mean } & Std Dev. & Mean & Std. Dev. \\
\hline 2002 & 6,464 & 13,930 & 585 & 1,092 \\
2003 & 11,723 & 45,245 & 364 & 552 \\
2004 & 14,310 & 44,882 & 1,369 & 3,913 \\
2005 & 5,005 & 1,837 & 683 & 1,226 \\
\hline
\end{tabular}

Before examining the individual hillside features, the sediment data from each watershed were examined to determine if sediment delivery was different among years. For both watersheds, Year was significant $(\mathrm{P}=0.034$ for the treatment watershed, $\mathrm{P}=<0.0001$ for the control watershed), so subsequent analyses to identify variables important to sediment delivery were performed by year.

The variables that were found to be important to explaining sediment delivery are presented in Table 3.2. For both watersheds within and across years, there were far fewer significant variables $(\alpha=0.10)$ than nonsignificant ones. Furthermore, not all variables were consistently significant or nonsignificant across years, though there were two that were consistently nonsignificant for both watersheds: tree fall soil area and distance to slope breaks. Distance to WDEFs and distance to tree falls were never significant in the control watershed, and bare soil area, distance to road, and distance to fillslope were never significant in the treatment watershed (Table 3.2). In the control watershed, across all years, bare soil area and distance to bare soil were clearly the variables that most consistently explained sediment delivery. Bare soil area was significant all four years, and distance to bare soil was significant three years (2002, 
2003, and 2005) and borderline significant the remaining year (2004). During pretreatment, only one variable was significant in the treatment watershed - distance to deer trails - though distance to bare soil again was borderline significant (Table 3.2). After road construction began, distance to WDEFs, distance to bare soil, and distance to tree falls became more important, and distance to deer trails was no longer significant. 
Table 3.2. Significance levels (P-values) of independent variables tested for explaining sediment delivery to the silt fence in the section-based analysis.

\begin{tabular}{|c|c|c|c|c|c|c|c|c|c|c|}
\hline Year & Slope & $\begin{array}{l}\text { Dist. Tree } \\
\text { falls }\end{array}$ & Bare Soil Area & Dist. To Slopebreaks & $\begin{array}{c}\text { Dist. To } \\
\text { Animal Trails } \\
\end{array}$ & Dist. To WDEFs & $\begin{array}{c}\text { Dist. To Bare } \\
\text { Soil }\end{array}$ & $\begin{array}{c}\text { Tree Fall Soil } \\
\text { Area }\end{array}$ & Dist. To Roads & $\begin{array}{c}\text { Dist. To } \\
\text { Fillslopes } \\
\end{array}$ \\
\hline \multicolumn{11}{|c|}{ Treatment Watershed } \\
\hline 2002 & 0.4792 & 0.1545 & 0.4043 & 0.2269 & 0.0868 & 0.8276 & 0.1064 & 0.6312 & . & . \\
\hline 2003 & 0.3651 & 0.7022 & 0.105 & 0.3223 & 0.909 & 0.0365 & 0.0418 & 0.7993 & 0.1709 & 0.8898 \\
\hline 2004 & 0.2124 & 0.0545 & 0.1126 & 0.5128 & 0.176 & 0.0002 & 0.0195 & 0.3917 & 0.6122 & 0.7385 \\
\hline 2005 & 0.6354 & 0.0036 & 0.159 & 0.8866 & 0.2779 & 0.0027 & 0.3422 & 0.2306 & 0.9843 & 0.9801 \\
\hline \multicolumn{11}{|c|}{ Control Watershed } \\
\hline 2002 & 0.415 & 0.8825 & $<.0001$ & 0.1325 & 0.5235 & 0.9272 & 0.0012 & 0.7921 & . & . \\
\hline 2003 & 0.2143 & 0.5104 & 0.0016 & 0.2473 & 0.0045 & 0.9767 & 0.0025 & 0.9969 & . & . \\
\hline 2004 & 0.2428 & 0.5204 & 0.0171 & 0.7167 & 0.6749 & 0.901 & 0.1136 & 0.7061 & . & . \\
\hline 2005 & 0.0068 & 0.2911 & $<.0001$ & 0.6751 & 0.081 & 0.4621 & 0.0001 & 0.9952 & . & . \\
\hline
\end{tabular}


The distance to bare soil obviously was an important variable explaining sediment delivery in both watersheds. As expected, generally the smaller the distance between bare soil and the silt fence, the greater the delivery (Table 3.3). Sediment levels associated with bare soil areas that were within $2 \mathrm{~m}$ of the silt fence accounted for 84 and 83 percent of the sediment delivered in the treatment and control watersheds, respectively, for those sections that had bare soil attributes associated with them.

Table.3.3. Mean mineral weight ( $\mathrm{g}$ ) of sediment delivery as a function of horizontal distance of the silt fence to bare soil areas. "Missing" refers to fence sections that had no associated bare soil areas.

\begin{tabular}{ccccc}
\hline & \multicolumn{2}{c}{ Treatment Watershed } & \multicolumn{2}{c}{ Control Watershed } \\
\hline $\begin{array}{c}\text { Distance to bare } \\
\text { soil class }(\mathrm{m})\end{array}$ & $\begin{array}{c}\text { Raw } \\
\text { Mean }\end{array}$ & $\begin{array}{c}\text { Standard } \\
\text { Deviation }\end{array}$ & Raw Mean & $\begin{array}{c}\text { Standard } \\
\text { Deviation }\end{array}$ \\
\hline 0 & 35,379 & 91,624 & 2,125 & 1172 \\
$>0$ to 1 & 7,713 & 13,455 & 2,468 & 5189 \\
$>1$ to 2 & 9,387 & 15,325 & 335 & 233 \\
$>2$ to 8 & 4,288 & 9,850 & 536 & 824 \\
$>8$ & 5,967 & 15,930 & 502 & 1474 \\
Missing & 6,981 & 21,939 & 595 & 1612 \\
\hline
\end{tabular}

While bare soil area was not ever significant for the treatment watershed, it was consistently for the control. Sediment delivery in the control watershed associated with bare soil areas that were in the $>4$ to $15 \mathrm{~m}^{2}$ and $>15$ to $50 \mathrm{~m}^{2}$ classes had much greater amounts of associated sediment delivery than the $>0$ to $4 \mathrm{~m}^{2}$ and $>50 \mathrm{~m}^{2}$ classes (Table 3.4). This may simply reflect that these former two are the most commonly occurring sizes of bare soil area present on the watershed, or that the smaller and larger areas were typically located further from the silt fence than the intermediate size areas. There was substantially greater total area in bare 
soil in the treatment watershed than in the control $\left(2484 \mathrm{~m}^{-2} \mathrm{vs.} 369 \mathrm{~m}^{-2}\right)$, which would help explain why the means for the treatment were much greater than for the control (Table 3.4).

Table 3.4. Mean mineral weight (g) of soil delivery as a function of the amount of bare soil area. "Missing" refers to fence sections that had no associated bare soil areas.

\begin{tabular}{ccccc}
\hline & \multicolumn{2}{c}{ Treatment Watershed } & \multicolumn{2}{c}{ Control Watershed } \\
\hline $\begin{array}{c}\text { Bare Soil Area } \\
\text { Class }\left(\mathrm{m}^{2}\right)\end{array}$ & Raw Mean & $\begin{array}{c}\text { Standard } \\
\text { Deviation }\end{array}$ & Raw Mean & $\begin{array}{c}\text { Standard } \\
\text { Deviation }\end{array}$ \\
\hline$>0$ to 4 & 11,958 & 53,180 & 473 & 616 \\
$>4$ to 15 & 5,913 & 7,340 & 2,041 & 4,760 \\
$>15$ to 50 & 12,575 & 57,769 & 1,167 & 1,880 \\
$>50$ & 21,232 & 42,611 & 118 & 89 \\
Missing & 6,927 & 21,941 & 595 & 1,612 \\
\hline
\end{tabular}

The distances between animal trails and the silt fence which were most important to explaining sediment delivery were the closest two distance classes for the control, and the furthest two distance classes for the treatment watershed (Table 3.5). Observations in the field indicated that sediment delivery to the fence was actually principally confined to locations where the animal trail intersected and crossed the fence. At these locations, there typically were sizeable sediment accumulations in the fence, but no evidence of sediment delivery at other portions of the section away from the point of intersection. Therefore, the influence that animal trails that are located relatively far from the fence have on sediment delivery is difficult to understand and interpret. 
Table 3.5. Mean mineral weight ( $\mathrm{g}$ ) of sediment delivery as a function of horizontal distance from animal trails. "Missing" refers to fence sections that had no associated animal trails.

\begin{tabular}{ccccc}
\hline & \multicolumn{2}{c}{ Treatment Watershed } & \multicolumn{2}{c}{ Control Watershed } \\
\hline $\begin{array}{c}\text { Distance from } \\
\text { Animal Trails }\end{array}$ & Raw & Standard & & $\begin{array}{c}\text { Standard } \\
\text { Deviation }\end{array}$ \\
Class $(\mathrm{m})$ & Mean & Deviation & Raw Mean & 549 \\
$>0$ to 0.5 & 9,439 & 26,183 & 674 & 2,132 \\
$>0.5$ to 6 & 1,911 & 2,730 & 1,321 & 316 \\
$>6$ to 14 & 16,229 & 56,372 & 316 & 546 \\
$>14$ & 11,709 & 24,031 & 305 & 2,430 \\
Missing & 8,852 & 31,657 & 799 & \\
\hline
\end{tabular}

The distance to tree falls illustrates what was observed in the field: tree falls that were very close to the fence contributed far greater sediment than those that were only slightly further away (Table 3.6). There was a drastic difference in the amount of sediment in the treatment watershed fence when the tree fall was within $1 \mathrm{~m}$ from the fence $(25,293 \mathrm{~g})$ than when it was just $4 \mathrm{~m}$ (or more) away $(4,669 \mathrm{~g})$. Mean delivery associated with distances at 4 and $9 \mathrm{~m}$ was very similar and surprisingly only about half that at 25 and $30 \mathrm{~m}$. There were no tree falls within $1 \mathrm{~m}$ of the fence in the control watershed, which may partially explain why distance to tree falls was not a significant variable for the control watershed.

Table 3.6. Mean mineral weight ( $\mathrm{g}$ ) of sediment delivery associated with horizontal distance from tree falls. "Missing" refers to fence sections that had no associated tree falls.

\begin{tabular}{ccccc}
\hline & \multicolumn{2}{c}{ Treatment Watershed } & \multicolumn{2}{c}{ Control Watershed } \\
\hline $\begin{array}{c}\text { Distance to Tree } \\
\text { Fall Class }(\mathrm{m})\end{array}$ & Raw Mean & $\begin{array}{c}\text { Standard } \\
\text { Deviation }\end{array}$ & Raw Mean & $\begin{array}{c}\text { Standard } \\
\text { Deviation }\end{array}$ \\
\hline$>0$ to 1 & 25,293 & 40,263 & NA & NA \\
$>1$ to 4 & 4,669 & 6,111 & 966 & 749 \\
$>4$ to 9 & 4,591 & 6,595 & 184 & 257 \\
$>9$ to 25 & 9,034 & 21,966 & 995 & 3,159 \\
$>25$ & 9,617 & 1,6804 & 322 & 272 \\
Missing & 8,283 & 38,880 & 771 & 2,196 \\
\hline
\end{tabular}


The area of exposed soil associated with tree falls was not a significant explanatory variable in either watershed. Presumably it is the presence and distance of the tree fall that is important, and not the size of the associated root wad. Trees which are large enough to uproot, whether from heavy snow loads, high winds, etc., instead of break likely have large root wads that have the potential to contribute high sediment masses to a stream if they are sufficiently close to it.

Slope was a significant explanatory variable for only one year (2005) in the control watershed and never for the treatment watershed (Table 3.2). This is contrary to the previous analyses that revealed an approximate 25 degree (43\%) contributing slope was important in affecting whether high or low levels of sediment were delivered. However, the previous analyses employed only 50 silt fence sections (the 25 most consistent high and low collections for both watersheds). The addition of sections that were not as consistent clearly influenced the results for both whole watersheds (Table 3.7).

Table 3.7. Mean mineral weight ( $\mathrm{g}$ ) of sediment delivery associated with hillside slope.

\begin{tabular}{|c|c|c|c|c|c|}
\hline & \multicolumn{2}{|c|}{ Treatment Watershed } & \multicolumn{2}{|c|}{ Control Watershed } \\
\hline \multicolumn{2}{|c|}{ Slope Class } & \multirow{2}{*}{$\begin{array}{l}\text { Raw } \\
\text { Mean }\end{array}$} & \multirow{2}{*}{$\begin{array}{c}\text { Standard } \\
\text { Deviation }\end{array}$} & \multirow{2}{*}{$\begin{array}{c}\text { Raw } \\
\text { Mean }\end{array}$} & \multirow{2}{*}{$\begin{array}{c}\text { Standard } \\
\text { Deviation }\end{array}$} \\
\hline (degrees) & $(\%)$ & & & & \\
\hline$>0$ to 20 & $>0$ to 35 & 6,075 & 17,201 & 647 & 1,401 \\
\hline$>20$ to 25 & $>35$ to 44 & 10,316 & 25,219 & 956 & 2,364 \\
\hline$>25$ to 30 & $>44$ to 52 & 6,397 & 24,539 & 1,098 & 4,360 \\
\hline$>30$ & $>52$ & 15,137 & 53,206 & 415 & 448 \\
\hline
\end{tabular}

The horizontal distance of water driven erosion features from the fence (WDEFs) was important in explaining sediment delivery in the treatment watershed after the road was constructed, but not before (Table 3.2). Those WDEFs that were closest to the fence were 
associated with the greatest masses of delivered sediment (Table 3.8). Antecedent seeps near the stream did contribute sediment to the fence; however, the fact that WDEFs became significant only after the road was constructed points to the road as being the important factor for this variable. Cross drains, particularly the culvert cross drains, are the likely source of much of the sediment delivered to the silt fence. It is unlikely that the broad-based dips played a large part in contributing sediment after BMPs were implemented because of the way the dip outlets are constructed and water is controlled. The high mass associated with the WDEFs in the $>15$ to 40 $m$ class is almost assuredly due entirely to cross drainage from the road. WDEFs never were significant in the control, but that may be because they were rarely present in the control, as indicated by the lack of WDEFs in the 0 to $0.5,>0.5$ to 3 , and $>15$ to $40 \mathrm{~m}$ classes.

Table 3.8. Mean mineral weight (g) of sediment delivery as a function of horizontal distance to WDEFs. "Missing" refers to fence sections that had no associated WDEFs.

\begin{tabular}{ccccc}
\hline & \multicolumn{2}{c}{ Treatment Watershed } & \multicolumn{2}{c}{ Control Watershed } \\
\hline $\begin{array}{c}\text { Distance to } \\
\text { WDEF Class } \\
(\mathrm{m})\end{array}$ & Raw Mean & $\begin{array}{c}\text { Standard } \\
\text { Deviation }\end{array}$ & Raw Mean & $\begin{array}{c}\text { Standard } \\
\text { Deviation }\end{array}$ \\
\hline$>0$ to 0.5 & 27,491 & 82,293 & - & - \\
$>0.5$ to 3 & 44,680 & 44,362 & - & - \\
$>3$ to 15 & 1,978 & 5,198 & 110 & 85 \\
$>15$ to 40 & 23,191 & 93,437 & - & - \\
$>40$ & 9,457 & 19,825 & 110 & 94 \\
Missing & 7,061 & 21,921 & 758 & 2,181 \\
\hline
\end{tabular}

The distance to the road within the treatment watershed was not a significant explanatory variable, despite that roads are reported to have largest influences on sedimentation and that other results, such as those described previously concerning the relationships of high sediment loads in silt fence sections within $30.5 \mathrm{~m}$ of the road, indicate the importance of the road. 
However, the mean data from the sections located within $70 \mathrm{~m}$ of the road do show that sections within $30 \mathrm{~m}$ of the road received much more sediment than those further away (Table 3.9). The apparent contradiction between sediment measurements and ANOVA significance tests can be explained by the fact that only a minority of the silt fence sections was responsible for the majority of sediment capture, and these were close to the road. Thus, there were many silt fence sections that were located further than $70 \mathrm{~m}$ from the road, which were included in the "missing" category and these as well as some closer sections that received little or no sediment contributions influenced the ANOVA results.

Table 3.9. Mean mineral weight ( $\mathrm{g}$ ) of sediment delivery as a function of the horizontal distance from the road surface. "Missing" refers to fence sections that had no associated Roads.

Treatment Watershed

\begin{tabular}{ccc}
\hline $\begin{array}{c}\text { Distance to Road } \\
\text { Class }(\mathrm{m})\end{array}$ & Raw Mean & Standard Deviation \\
\hline$>0$ to 15 & 24,091 & 71,613 \\
$>15$ to 30 & 24,483 & 77,742 \\
$>30$ to 50 & 3,283 & 4,716 \\
$>50$ to 70 & 6,757 & 18,372 \\
Missing & 7,229 & 19,049 \\
\hline
\end{tabular}

Analyses involving the distance between the fillslope and silt fence also showed this distance variable to be nonsignificant (Table 3.2). However, the large increase in the P-value in 2004 compared to 2003, suggests that the effect of the fillslope became much less important after it became at least partially revegetated. Delivery associated with fillslope distances is greatest within the first $25 \mathrm{~m}$, and after that, delivery decreases sharply (Table 3.10). The same reasons given for the distance from the road not being significant apply to distance from the fillslope. 
Table 3.10. Sediment delivery associated with the horizontal distance from the fillslopes. "Missing" refers to fence sections that had no association with the fillslopes.

\begin{tabular}{ccc}
\hline & \multicolumn{2}{c}{ Treatment Watershed } \\
\hline Distance to Fillslope & Raw Mean & Standard Deviation \\
Class $(\mathrm{m})$ & 17,957 & 70,497 \\
$>0$ to 10 & 31,411 & 89,619 \\
$>10$ to 25 & 5,288 & 12,818 \\
$>25$ to 45 & 5,458 & 15,388 \\
$>45$ to 65 & 6,684 & 14,397 \\
$>65$ & 7,849 & 21,215 \\
Missing & &
\end{tabular}

\subsection{Contributing Area Analyses}

The contributing areas that were included in the high and low sediment delivery groups for the treatment and control watersheds are shown in Figure 3.5 and 3.6. The distributions of the high and low contributing areas within the treatment watershed are related to the sediment sources within those contributing areas. As Figure 3.5 shows the high group of contributing areas correspond to areas where major sediment contributors exist. For example, all the high group contributing areas contain silt fence sections which are downslope of the road fillslope. Areas 1, 2, 3, and 4 also contain silt fence sections that are below stream crossings, alluding to the influence from the stream crossings and their associated fills. 


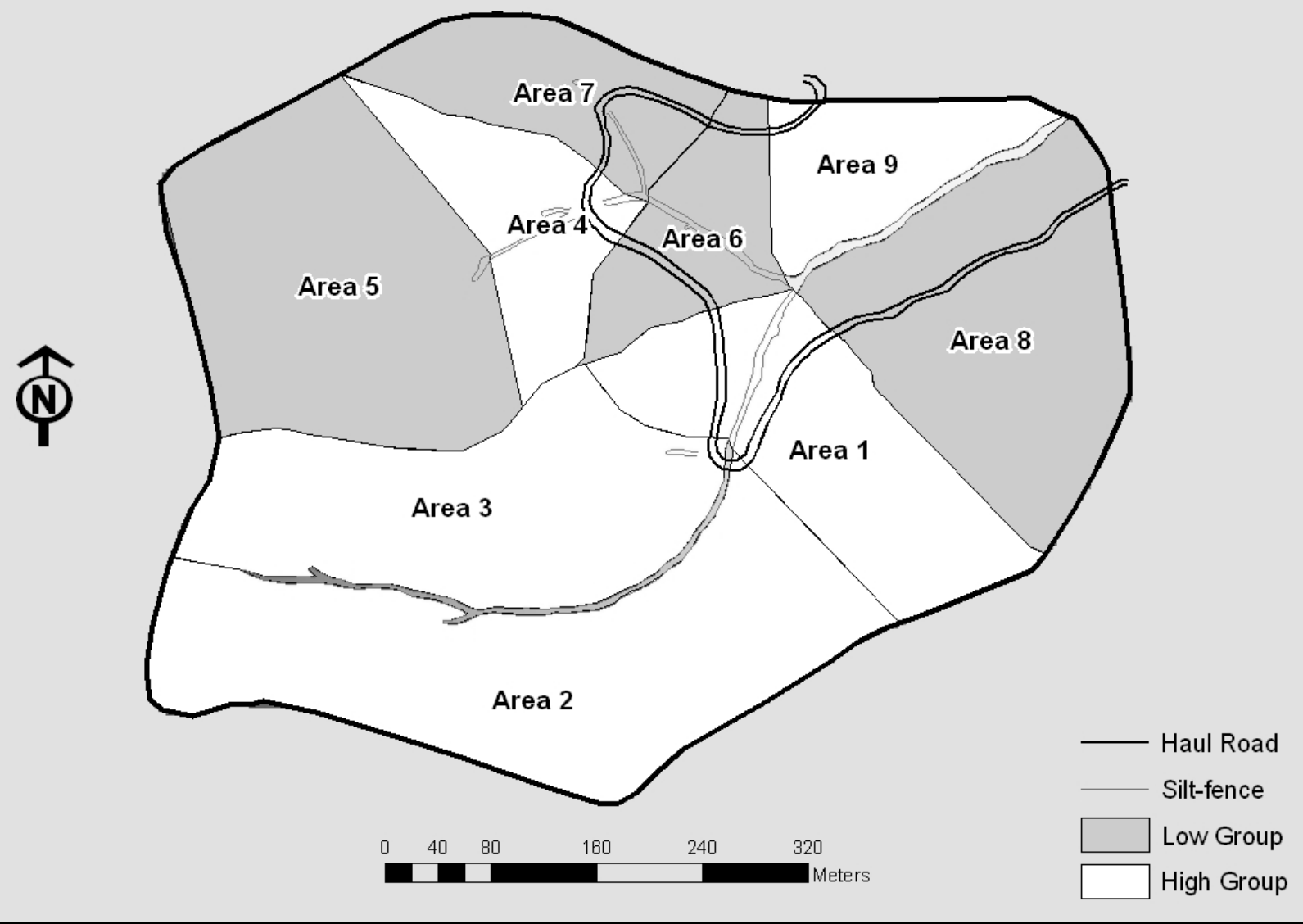

Figure 3.5. Treatment watershed high and low contributing area subgroups.

The distributions of the high and low contributing areas within the control watershed are also related to sediment sources that exist within the boundaries of each particular contributing area. Contributing areas 1,4 , and 8 are grouped around steep tributaries which have various major sediment sources including tree falls and bare soil areas. Contributing area 10 does not include a major tributary; however, it is steep, exceeding 30 degrees (53\%) in some places, and contains various important sediment sources including tree falls and areas of bare soil. 


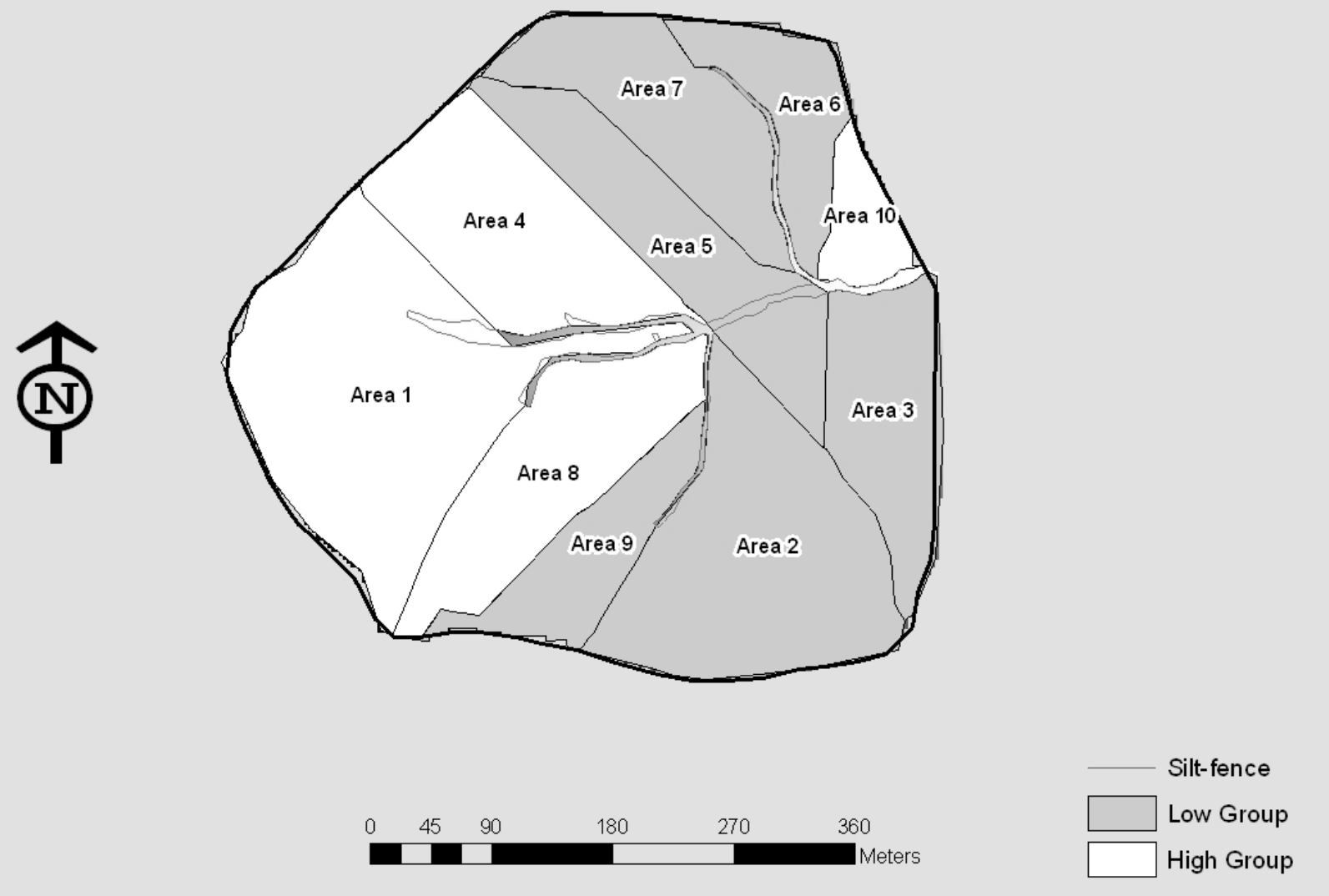

Figure 3.6. Control watershed high and low contributing area subgroups.

The contributing area analyses differs from the section-based analyses in that the contributing area analyses employs a single average value for each hillside feature (i.e., independent variable) within the contributing area to predict sediment delivered on an area basis (i.e., total sediment for the silt fence sections in the contributing area divided by the total area within each contributing area (see section 2.7.2)). Furthermore, because average values are used (i.e., $n=1$ for each independent variable within each contributing area) data for all years must be pooled together, and annual analyses cannot be performed. Because this analysis involves very 
different approaches, different explanatory variables are expected to result from this modeling approach.

The results for the contributing area analyses show each variable was important to explaining sediment delivery for the low sediment group in the control watershed (Table 3.11). For the treatment watershed many, but not all, of the variables also were significant for the low sediment group (Table 3.11). By contrast, many fewer variables were significant for the high group in both watersheds. In the control watershed, the significant variables were confined only to the distance and area variables for bare soil and tree falls. In the treatment watershed, only the distance to bare soil and distance to fillslopes were important. 
Table 3.11. Significance levels (P-values) for independent variables tested for explaining sediment delivery to the silt fence in the contributing area analysis.

\begin{tabular}{|c|c|c|c|c|c|c|c|c|c|c|}
\hline $\begin{array}{l}\text { Watershed } \\
\text { Grouping }\end{array}$ & Slope & $\begin{array}{c}\text { Dist. Tree } \\
\text { falls }\end{array}$ & Bare Soil Area & $\begin{array}{c}\text { Dist. To } \\
\text { Slopebreaks } \\
\end{array}$ & $\begin{array}{c}\text { Dist. To Deer } \\
\text { Trails } \\
\end{array}$ & Dist. To WDEFs & $\begin{array}{c}\begin{array}{c}\text { Dist. To Bare } \\
\text { Soil }\end{array} \\
\end{array}$ & $\begin{array}{c}\text { Tree Fall Soil } \\
\text { Area } \\
\end{array}$ & Dist. To Roads & $\begin{array}{c}\text { Dist. To } \\
\text { Fillslopes }\end{array}$ \\
\hline \multicolumn{11}{|c|}{ Treatment Watershed } \\
\hline High & 0.3321 & 0.4912 & 0.4345 & 0.7239 & 0.3916 & 0.2165 & 0.057 & 0.5494 & 0.3286 & 0.0754 \\
\hline Low & 0.0532 & 0.3493 & 0.0022 & 0.0096 & 0.0095 & 0.8152 & 0.0139 & 0.007 & 0.5855 & 0.6297 \\
\hline \multicolumn{11}{|c|}{ Control Watershed } \\
\hline High & 0.1365 & 0.0361 & 0.0298 & 0.3411 & 0.1126 & 0.1967 & 0.0361 & 0.0361 & . & . \\
\hline Low & 0.0002 & 0.0009 & 0.0594 & 0.026 & 0.0594 & 0.0155 & 0.0179 & 0.0119 & & \\
\hline
\end{tabular}




\subsection{RUSLE Prediction Results}

The RUSLE delivery prediction was calculated by multiplying the modeled GIS RUSLE estimate by 0.52 as recommended by Gianessi et al. (1986), where they stated that this was the estimate of the ratio for gross erosion to sediment delivery for West Virginia forestlands. Even with this correction, the soil loss predictions resulting from RUSLE were much higher than the actual sediment collected from the silt fences within both study watersheds. The modeled estimate for the treatment watershed was 2.68 tons per-acre per-year, while the modeled estimate for the control watershed was 2.86 tons per-acre per-year. These values are comparable to the estimate by Gianessi et al. (1986) for West Virginia forestlands of 2.07 tons per-acre per-year as interpreted by Hood et al. (2002). However, the treatment watershed actually produced $0.01,0.02,0.03$ and 0.01 metric tons of sediment per-acre, respectively, for 2002 through 2005; while the control watershed produced $0.002,0.001,0.005$, and 0.003 tons per-acre, respectively, for 2002 through 2005 . The soil loss prediction was 134 times higher than the average mass collected for the treatment watershed and 953 times greater than the average mass collected from the control watershed during those years. 


\section{CHAPTER 4 - DISCUSSION AND CONCLUSIONS}

\subsection{Statistical Results and Comparisons}

The results from the Generalized Linear Models (GLM) in these analyses illustrates that many factors have an affect on the soil movement process to some degree and display patterns of increasing or decreasing affect with changes in the value for each topographical feature of interest. However, these variables were not always found to be significant even though they clearly display an indicative pattern of affect on hill-slope soil movement at particular locations.

The two techniques used to analyze the data yielded different results, which can be linked to the difference in the occurrence and distribution of different watershed attributes. In the sectionbased analysis, the significant explanatory variables changed from year-to-year because the factors that controlled sediment contributions changed from year-to-year. The large variability between silt fence sections, with regard to sediment captured, is indicative of how localized existing sediment sources are extremely variable, even those sediment sources which are comparable in type, size, shape, and distance from the stream channel exhibit extreme variability in sediment contributions. This annual variation combined with the fact that the largest contributors or controllers of sediment delivery, such as road fillslopes, bare soil areas, or tree falls, were present in and affected only a small portion of each watershed, resulting in a large variability in sediment collections among silt fence sections. Consequently, the analysis of variance results typically showed most variables to be unimportant in explaining sediment delivery in the section-based analyses. The bias of the section-based analysis is to identify only more frequently occurring variables as significant, even if they are not large contributors overall to a watershed.

By contrast, the contributing area analyses simply used a single average for each attribute expressed on a per areas basis for each contributing area over the entire study period (2002- 
2005). Grouping the areas into high and low sediment categories allowed the analysis to identify the variables that were most important for controlling or contributing very high sediment yields, such as the fillslopes, in the high groups. However, these large inputs dominated these findings of this analytical approach, so that more consistently-occurring but less important contributors (i.e., the sediment associated with those variables was small but consistent through time) generally would not be identified as significant in the high sediment group. Conversely, in the low sediment group, the analysis was not dominated or overwhelmed by the inputs of one or a few major contributors, so that those less important and typically more consistent contributors of sediment, such as bare soil areas, could be identified. An overall drawback of the contributing area approach was the inability to consider the years individually, so that the effects of even naturally changing conditions, such as precipitation, could not be considered directly or indirectly when interpreting the results. Overall, however, the results from the contributing area analyses better supported field observations and some of the initial analyses of this study (e.g., road effects being greatest where the fillslope was nearest to the stream) than the section-based analyses.

The average sediment yields from the two study watersheds, 0.007 tons/ha/yr $(0.003$ tons/ac/yr) for the control watershed and 0.049 tons/ha/yr $(0.02$ tons/ac/yr) for the treatment watershed, were considerably less than the 0.05 to 0.10 tons/ac/yr considered normal for undisturbed and carefully managed lands (Patric 1976; Douglas 1975). Additionally, the average sediment yielded from the treatment watershed in this study was less than the 0.15 tons/ha/yr ( 0.06 tons/ac/yr) recorded for a "no treatment" control watershed in a study by Kochenderfer and Helvey (1984) but slightly more than the 0.016 tons/ha/yr yielded from a long undisturbed forested watershed as reported by Kochenderfer et al. (1987). Both these studies took place in 
areas near the treatment watershed (within a 10-mile radius of Parsons, West Virginia).

Kochenderfer and Helvey (1984) also reported a rapid decrease in sediment yields following the end of logging treatments in the same study, similar to the findings of this study. Supporting the visual observations made throughout this study they attributed this decrease to the establishment of vegetation which stabilized the eroding soil. The majority of the difference in sediment yields between the control and treatment watersheds is likely attributable to the road construction treatments but some differences may simply indicate the differences between the two watersheds; as Kochenderfer et al. (1987) reported that the stability of stream channels and banks vary widely even among undisturbed watersheds due to differences in channel slopes, rock abundance, and stream sinuosity.

\subsection{RUSLE Predictions}

Knowledge about sediment delivery processed and the related components is limited, which in turn limits the development of sophisticated physically-based models for predicting sediment yield (Croke and Hairsine 2006). Sediment delivery involves factors, such as hillslope shape, soil type, vegetation, rainfall intensity, and the degree of disturbance within a watershed, and these factors, as well as sediment sources also vary spatially, particularly within forested watersheds (Croke and Hairsine 2006). Consequently, prediction models that are overly simplistic likely will predict sediment delivery poorly.

From the data in this study, the RUSLE greatly overestimated soil loss for both study watersheds. The poor performance of this equation may be attributed to several factors, particularly the extensive spatial variability in sediment generations. The additional changes to the treatment watershed from the creation of the road prism also added complexity to the treatment 
watershed that was well beyond the parameters that can be modeled well by the RUSLE. But even with the creation of the road prism in the treatment watershed, which created extensive and important erosion features, the RUSLE still greatly overestimated sediment yields compared to the measured 2003 and 2004 yields.

The RUSLE was initially designed for relatively flat, homogenous agricultural lands. Even with modifications for forested areas, applying the RUSLE to steep forested landscapes, similar to those used in this study and throughout the Appalachian region, probably reaches outside the realm of the predictive capabilities of these equations. The RUSLE also was designed to model only sheet and rill erosion. While these can occur in forested watersheds, they were not observed to be the predominant types of sediment delivery on these two watersheds. For example, mechanical additions to the silt fence during road construction were the largest single sources of sediment inputs. Other large inputs from sources, such as root wads, also were not by sheet or rill erosion.

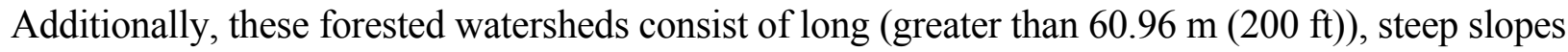
covered with leaf litter, and other organic materials, which the RUSLE also is not well suited to consider in its parameter coefficients. The RUSLE relies on linearity of slopes and homogeneity of conditions, which are not present on these specific watersheds and generally do not occur in forested watersheds. Because the coefficients and mathematical form of the RUSLE have room for alteration to bring the predictions close to measurements, the sediment delivery ration described by Gianessi et al. (1986) would require a significant modification to fit the existing conditions for these watersheds.

Most simulation models are unsuitable for defining the spatial extent of hydrologically active areas; thus, they are incapable of determining the location and the type of sediment sources which exist within any particular watershed. The incapability to account for all sediment sources 
means that sediment delivery results are predicted without information about all of the significant contributing sources. Inaccuracies may also be attributed to the fact that each sediment source has an individual delivery pattern which is dependent upon its location within a watershed and the management practices employed to control such sediment movement throughout such a watershed (Croke and Hairsine 2006).

From the results of this study, models to predict sediment delivery to streams must be able to include considerations of the non-uniform location of sediment sources, including giving more importance to those in close proximity to the stream or otherwise connected via water to the stream (e.g., cross drainage), as well the heterogeneity of the amount of sediment contributed by different sources. The predictions resulting from the RUSLE were highly overestimated, and thus, provide little insight into soil loss or the processes involved. Modifying the input variables of the RUSLE may reduce the predictions somewhat, but the equation still lacks the ability to be widely applicable and probably would need calibrated modification for every forested watershed to which it would be applied. The lack of accuracy without significant intervention from the user makes the usefulness of the RUSLE questionable when applying it to a forested watershed.

\subsection{Management Implications}

The variability in mineral masses among the silt fence sections, illustrates that sediment sources, even the most important ones on a watershed scale, are discrete and local in their extent. This finding coupled with the close proximity to streams of most of the important (to-stream) sediment contributors indicates that stream sedimentation control should be most effective when it is focused on the discrete inputs. Being able to better identify and target important contributors also will make sediment control more cost effective. 
The primary factor affecting sediment in the treatment watershed was the road. Its construction greatly increased sediment delivery, and resulted in values that were much greater than those present before and after road construction, or those present at any time on the control watershed. The road design and construction led to enormous additions of sediment to the silt fence (otherwise effectively to the stream) primarily due to the steep fillslopes in the stream crossing approaches (especially the first stream crossing). Additionally, the poor BMP application during the first nine months after road construction allowed sediment material from these areas to move down slope basically unimpeded, including further erosion of the fillslopes that encroached near the stream. Once BMPs were properly in place and the disturbed soil started to stabilize, collected sediment masses decreased $182 \%$ from 2004 to 2005 in the treatment watershed. Similar to the findings of Reidel (2003) where he reported a $71 \%$ reduction in sediment yields after BMP application despite a $46 \%$ increase in precipitation over a four month period. Consequently, the first management implication identified through this study is implementing sediment control techniques, such as BMPs, as soon as feasible after the onset of an operation, as BMPs are essential to preventing non-point source stream pollution and protecting aquatic biology at the beginning of, and during an operation (Stuart and Edwards 2006). Kochenderfer and Wendel (1980), Edwards and Owens (1991), Alpert et al. (1995), and Breshears et al. (1999) all reported that sediment moves rapidly and the majority of movement occurs in a short period of time, so BMPs have to be in place immediately following the development of a disturbance; if they are not sedimentation will increase rapidly as indicated by the increase in sediment in 2003 while BMPs were not in place or implemented poorly; similar to the findings by Reinhart et al. (1963) when they reported that a clearcut watershed with no BMP application had a considerable amount of sediment delivered to the stream in a very short period indicated by an increase in stream 
turbidity they were measuring. Additionally, Lynch et al. $(1975,1985)$ reported that properly constructed BMPs will not prevent all off-site impacts; however, the impacts will be small and of no concern to water quality standards.

The BMP guidelines need to be followed properly for optimal results. Essentially, BMPs were followed in this study; however, the fillslope material encroached upon the stream as a result of mechanically being pushed down the slope and accounted for the majority of the sediment collected. BMPs work well, as shown by Kochenderfer and Hornbeck (1999), and if properly used can reduce the impact of soil movement and sedimentation significantly. Kochenderfer and Hornbeck (1999) added that the proximity of roads to streams is probably the single most important attribute that determines whether streams will be adversely impacted by timber harvesting. The BMP guidelines suggest that roads cross the stream at a right angle and continue around the contour once the road is 100 -feet (slope distance) from a Perennial or Intermittent stream and 25 feet from an Ephemeral stream. A factor influencing this distance is slope steepness as Trimble and Sartz (1957) and Haupt (1959) found that slope gradient was the key in determining the distance sediment moved from roads. Swift (1986) added that downslope sediment movement can range from $0.61 \mathrm{~m}$ to $95.71 \mathrm{~m} \mathrm{(2} \mathrm{to} 314 \mathrm{ft})$ depending on site and road conditions. However, this study identified the distance to the fillslopes of the road as one of the primary elements affecting sediment contribution to stream channel, not the road itself, and once the fillslope material was $\geq 25 \mathrm{~m}$ from the stream, sediment contributions to the stream declined substantially. One key objective of management this study emphasizes is to maintain a safe distance between the stream and the sediment source, primarily the fillslopes as the location of naturally bare soil and tree falls (other major sediment sources) can hardly be managed, to prevent elevated sediment inputs. As a general rule of thumb a $30 \mathrm{~m} \mathrm{SMZ} \mathrm{width} \mathrm{is} \mathrm{regarded} \mathrm{as} \mathrm{sufficient}$ 
for preventing all significant impacts of management activities (Davies and Neilson, 1994) this is similar to the $25 \mathrm{~m}$ found in this study; however, the $25 \mathrm{~m}$ in this study refers to horizontal distance not slope distance. This $25 \mathrm{~m}$ horizontal distance also needs to be maintained between the stream and the fillslopes not simply the road surface itself as the road contributed little sediment within the treatment watershed. However, if extreme slopes or extraordinary sediment sources exist, further planning or greater SMZ widths may be required to prevent significant detrimental impact as a result of elevated sediment inputs. More research may have to be done to determine specific distances for various slopes, soils, and topographic erosion features.

Constructing roads in the steep terrain of the treatment watershed with stream crossings and deep fills over those crossings creates a tremendous amount of disturbance and a number of problems. 1) The fill-slope material and the amount of road surface area, which have the ability to erode and impact water quality, is greatly increased because the road virtually parallels the stream around the hill-slope for considerable distances on the approach and departure from the stream crossing. 2) The water that is drained off the road is simply directed over the fillslope, picks up large quantities of mineral material from the freshly disturbed fillslope, and eventually runs down the slope and into the stream. 3) A combination of water and gravity transport the lose fillslope material toward the stream channel, which is reached quickly and easily due to the short distance and lack of obstacles in its path. Alpert et al. (1995) stated that road stream crossings are a significant source of erosion, and that road crossing size is the variable that determines the magnitude of this erosion source. This study identified mechanical additions from the fillslopes to be the major source of sediment related to the stream crossings. Since the cut-and-fill slopes are frequently on significant slopes the stabilization of these disturbed areas is essential to prevent early soil loss during the onset of an operation and to maintain the integrity of the road surface for 
the duration of the management operation. The fillslopes, being downslope of the road towards the stream channel, play a more significant role in the contribution of sediment to the stream than do the cutslopes above the roads. However, proper sloping of both the cut-and-fill slopes will help prevent slipping of the soil on these slopes. Both the cut-and-fill slopes should not exceed a 25 degree angle. The slipping of cut slope material can lead to the obstruction of road ditches, and other water control structures, which can result in surface flow damaging the cutslope, the road surface, and the fillslope and lead to accelerated erosion. The slipping of fillslope material can lead directly to sedimentation of the water body downslope. To prevent this erosion cut-and-fill slopes and roads should be graded to a minimum angle and immediately seeded and mulched as soon as they will no longer be disturbed. One management option to resolve this problem is to build the road completely on residual soil, preventing the sidecasting of fillslope material essentially eliminating the problems associated with the fillslopes, all though this is not a common practice in the study region.

The use of temporary bridges and other crossing techniques will help eliminate some of these problems as well. Crossing streams with temporary or permanent bridges can result in much less disturbance than the installation of culverts. This also reduces or eliminates work in the stream with heavy equipment, thus, leading to less in-stream disturbance and sedimentation. Modern temporary bridges can be placed across streams or channels causing little disturbance to stream banks so little sediment is contributed to the stream channel. There are numerous producers of these modern temporary bridges with prices ranging from a few hundred to several thousand dollars. Depending on the producer of the bridge it may be assembled for a single application or may have the ability to be modified to satisfy nearly every stream crossing need. Current technology has made these bridges durable enough that the ability to reuse them and pricing can 
make them competitive with culverts and even fords (Brinker et al. 1997, Thompson and Stringer 2003). Loggers have even reported portable timber bridges actually easier to install than culverts or bridges built on-site (Thompson and Stringer 2003).

The use of gravel on constructed haul roads can be very beneficial as well, as it can reduce soil movement and the subsequent sedimentation by protecting and stabilizing the road surface; as well as filtering out sediment carried by water flowing over the road surface. All though the road was not identified as a significant sediment source in this study some sediment was produced from the road surface itself while it was bare of gravel and/or vegetation. Croke and Hairsine (2006) reported that minimizing road and ditch erosion is essential in providing a quality road surface that requires minimal maintenance while at the same time limiting the delivery of sediment to streams.

Substantial erosion also occurred in the treatment watershed because insufficient planning was given to considering the stream water routing in the second tributary. Had riprap either been applied immediately on the fillslope onto which the tributary was first directed, or had the tributary been initially rerouted through the riprapped ditchline (as was eventually done), the large amount of erosion that resulted could have been avoided. A smaller amount of sediment delivery came from two road cross drains near the first stream crossings. These perhaps could have been avoided by providing riprap below these structures, as was done for all broad-based dips in the watershed.

Another point of important managerial consideration are the residual trees within a managed watershed; that is, the trees left behind after a harvest operation. After a considerable portion of the basal area is removed from a stand by harvesting, the residual trees are often windblown or fall down due to the fact that they are exposed to more direct wind currents which they have never experienced and cannot withstand as this was visually observed numerous times during this study. These treefalls can contribute a significant quantity of sediment if they are close 
to the stream channel (4 $\mathrm{m}$ or less). Preventing this erosion and sediment movement requires

preventing the tree fall, essentially to prevent the tree fall more protection must be left for the residual trees; that is, leaving more trees in a group to withstand the wind not simply leaving a few individual trees without any protection. This point should be stressed even more in areas of moist to wet soil. Conversely, if certain trees or species display a tendency towards uprooting or windthrowing the possibility of harvesting these trees should be considered; however, these tree harvests should not be extensive to the point of increasing thermal inputs to the stream and should not permit equipment operation within the SMZ. The felled trees should be removed by directionally felling them outside of the SMZ where they can be picked up or winching the trees out of the SMZ using a cable skidder. Directional felling should also be implemented on all tree harvesting so as not to damage, weaken, or even knock down the desired residual trees.

Essentially the management implications derived from the results of this study are:

- Minimize soil surface disturbance:

o Plan more efficient roads that reach more areas

o Do not construct unneeded roads

- Apply BMPs thoroughly and quickly during and after an operation.

- Focus sediment control more acutely on the discrete areas of contribution:

o Fillslopes and cutbanks-especially approaching streams

o Road drainage outlets

o Tree falls-residual trees

o Bare soil areas

- Avoid constructing roads parallel to streams on the approach and departure from crossings.

- Keep fillslope material $>25 \mathrm{~m}$ (horizontal distance) from the stream channel.

- Properly grade and stabilize all areas of disturbance.

o Cut-and-fill slopes

o Roads

0 Landings

o Skid Trails

o Others

- Riprap all water drainage outlets to prevent channeling and erosion of soil.

- Use stream crossing structures such as temporary bridges where possible.

- Consider treatments for residual trees:

o Leave enough trees to protect or shield desired residual trees. 
o Use directional felling to prevent damage to residual trees.

o Consider harvesting the trees if they are likely to fall if left standing.

\subsection{Conclusions}

Peak sediment delivery occurred during and directly after the haul road construction process. The majority of sediment came from the road fillslopes located just downslope of the stream crossings

Sedimentation in the two study watersheds was dominated by a few definable primary sources within each study watershed. That is, within the treatment watershed, the primary sediment sources were identified as the fillslopes associated with the roads, primarily the fillslopes which were close to stream crossings $(<25 \mathrm{~m})$, and the bare soil areas within $2 \mathrm{~m}$ of the stream channel.

The primary sediment sources within the control watershed are, similarly, the largest areas of exposed soil within those watersheds, the soil associated with tree falls (typically $<4 \mathrm{~m}$ ), and the bare soil areas $(<2 \mathrm{~m})$. Because the treefalls account for a significant quantity of sediment within an undisturbed environment we must assume the tree falls in a disturbed environment account for just as much sediment contribution. However, residual trees, present during and after a harvest, need to receive more managerial consideration from foresters due to there increased risk of knockdown and windthrow during and after a harvest which could in-turn increase sediment inputs and decrease timber and soil productivity. The application of sound control techniques to these areas is essential in preventing elevated sediment inputs and protecting the resources of soil, water, and timber at these sites.

Modeling soil erosion in forested watersheds remains a difficult task. The RUSLE estimated sediment delivery poorly in both the control and treatment watershed. Sediment was 
overestimated by an average of 134 times and 956 times in the treatment and control watersheds, respectively. The RUSLE is an overly simplistic model for complex forested terrains where there are highly heterogeneous surface and slope conditions, complex erosion processes that are dominated by discrete sediment sources. 


\section{LITERATURE CITED}

Alpert, M., Best, D.W., Hagans, D.K, Kelsey, H.M. 1995. Role of Fluvial Hillslope Erosion and Road Construction in the Sediment Budget of Garret Creek, Humboldt County, California. U.S. Geologic Survey Professional Paper.

Barfield, B.J., R.C. Walker, and C.T. Haan. 1983. Applied hydrology and sedimentology for disturbed areas. Stillwater, OK: Oklahoma Technical Press.

Barling, R.W. and Moore, I.D. 1994. Role of buffer strips in management of waterway pollution: a review. Journal of Environmental Management. Vol. 18: 543-558.

Beaseley, R.S. 1979. Intensive site preparation and sediment losses on steep watersheds in the Gulf coastal plains. Soil Science Society Am. J. 43:412-417.

Beschta, R.L. 1978. Long-term patterns of sediment production following road construction and logging in the Oregon Coast Range. Water Resources Research 14(6):1011-1016.

Best, David W., Harvey M. Kelsey, Danny K. Hagans, and Mark Alpert.

Better Soils Project, Agriculture Bureau of South Australia, 1997. Module 3.9 Soil Water Holding Capacity. http://www.bettersoils.com.au/module3/3_09.htm. Last visited 7/30/07.

Bilby, R.E., K. Sullivan, S.H. Duncan. 1989. The generation and fate of road surface sediment in forested watersheds in southwestern Washington. Journal of Forest Science. Vol. 3: pp.453-468.

Bill, M.D. 2005. Channel morphology and substrate responses to high flows and road construction in forested mid-Appalachian watersheds. M.S. Thesis, Southern Illinois University, Carbondale, IL. 64 p.

Bonnell, M., and Williams, J. 1986. The generation and redistribution of overland flow on a massive oxic soil in eucalypt woodland within the semi-arid tropics of north Australia. Journal of Hydrologic Process. Vol. 1: 31-46.

Bormann, F. H., and Likens G. E. 1979. Pattern and process in a forested ecosystem. Springer Verlag, Inc., New York.

Breshears, D.D., MacDonald, L., Reid, K.D., Wilcox, B.P. 1999. Runoff and Erosion in a PinonJuniper Woodland: Influence of Vegetation Patches. Journal of American Soil Science Society Vol. 63 1869-1879.

Brinker, Richard W. and Steven E. Taylor. 1997. Portable Bridges For Forest Road Stream Crossings. Alabama Cooperative Extensions System in Cooperation with the USDA. 
Brown, R.B. 2003. Soil Texture. University of Florida, Institute of Food and Agricultural Services Extension. http://edis.ifas.ufl.edu/SS169. Last visited 7/26/2007.

Bruijnzeel, L.A. 1990. Hydrology of moist tropical forests and effects of conversion: A state-ofknowledge review. Paris: Preceding the UNESCO International Hydrological Program.

Burroughs, E.R., Jr.; King, J.G. 1989. Reduction of soil erosion on forest roads. Gen. Tech. Rep. INT-264. Ogden, UT: U.S. Department of Agriculture, Forest Service, Intermountain Forest and Range Experiment Station. 21 p.

Case, A.B., and J.G. Donnelly. 1979. Type and extent of ground disturbance following skidder logging with rubber-tired skidders. J. Soil and Water Conserv. 28(5): 218-220.

Castro. C.D., and T.M. Zobeck. 1986. Evaluation of the Topographical Factor in the Universal Soil Loss Equation on Irregular Slopes. J. Soil Water Conserv 41: 113-116.

Clinnick, P.F. 1985. Buffer strip management in forest operations: a review. Australia Forestry Vol. 48: 34-45.

Constantini A, R.J. Loch, R.D. Connolly, and R. Garthe. 1999. Sediment generation from forest roads: bed and eroded sediment size distributions, and runoff management strategies. Australian Journal of Soil Research Vol.152: pp. 293-312.

Copley, T.L., L.A. Forrest, M.T. Augustine, and J.F. Lutz. 1944. Effects of land use and season on runoff and soil loss. N. Carolina Agr. Exp. Sta. Bull. 347. 28p.

Corbett, E.S., J.A. Lynch, and W.E. Soper. 1978. Timber harvesting practices and water quality control in the Eastern United States. J. For. 48: 11-14.

Croke, Jacky, Fogarty, Peter, Hairsine, Peter 1999. Sediment transport, redistribution and storage on logged forest hillslopes in south-eastern Australia. Journal of Hydrological Processes Vol. 13: 2705-2720.

Croke, J.C, Hairsine, P.C., and Fogarty, P. 1999b. Sediment production, storage and redistribution on logged hillslopes. Journal of Hydrological Processes. Vol. 13:2705-2720.

Croke, J.C. and Hairsine, P.B. 2006. Sediment Delivery in managed forests: a review. Journal of Environmental Reviews Vol. 14: 59-87.

Dissmeyer, G.E., and G.R. Foster. 1981. Estimating the cover management factor (C) in the universal soil loss equation for forest conditions. J. Soil Water Conserv 36(4): 235-40.

Douglas, J.E. 1975. Southeastern forests and the problem of non-point sources of water pollution. In: Non-point sources of water pollution. Southeastern Region Conference Proceedings: Blacksburg, Virginia. Virginia Polytechnic Institute and State University. pp. 2944. 
Douglas, I., T., Sinum, W., Anderton, S., Bidin, K., Spilsbury, M., Suhaimi, J., and Bin Sulaiman, A., 1995. Geomorphology and rainforest logging practices. In Geomorphology and land management in a changing environment. Edited by D.F.M. McGregor and D.A. Thompson. Wiley, Chichester, UK. pp. 309-320.

Dyrness C. T. 1965. Soil surface condition following tractor and high-lead logging in the Oregon Cascades. J. Forestry April 1965.

ESRI Press. 1995. ARC Macro Language. Redlands, CA: ESRI Press. 828 p.

Edwards, Pamela J. In Progress. Instream Turbidity Changes From Forest Haul Road Construction.

Edwards, W.M., and L.B. Owens, 1991. Large storm effects on total soil erosion. J. of Soil and Water Conservation. V.46:75-78.

Egan, A. F., and Rowe, J. P. 1997. Compliance with West Virginia Silvicultural Best Management Practices 1995-1996. WV DOF Tech. Rpt. 97-1 (6/97) pp. 19.

Egan, A. F., Whipkey, R. D., and Rowe, J. P. 1998. Compliance with Forestry Best Management Practices in West Virginia. Northern J. of Appl. For. 15(4) p211.

Eisenbies, Mark H., J.A. Burger, W.M. Aust, and S.C. Patterson. 2005. Soil Physical Disturbance and Logging Residue Effects on Changes in Soil Productivity in Five-Year-Old Pine Plantations. Soil Science Society of America.

Elliot, W.J., D.E. Hall, and S.R. Graves. 1999. Predicting Sedimentation from Forest Roads. J. Forestry August 1999.

Elliot, W.JR.B. Foltz, and C.H. Luce. 1995. Validation of the Water Erosion Prediction Project (WEPP) Model for Low Volume Forest Roads, In Proceedings of the Sixth International Conference on Low Volume Roads, 178-186. Washington D.C: Transportation Research Board.

Florida Department of Environmental Regulation, 1988. The Florida development manual: A guide to sound land and water management. Chapter 2. Tallahassee, Fl.

Foster, G.R., and L.J. Lane. 1987. User Requirements. USDA-Water Erosion Prediction Project (WEPP). NSERL Report No. 1. USDA, ARS, National Soil Erosion Research Laboratory, W. Lafayette, Indiana.

Froehlich, H. A. 1979. Soil compaction from logging equipment: effects on the growth of young ponderosa pine. J. Soil Water Conserv. 34:276-278.

Gianessi, L.P., H.M. Peskin, C.A. Puffer. 1986. A national data base of nonurban-nonpoint-source discharges and their effect on the nation's water quality. USGS No. CR811858-01-0. 
Grayson, R.B., Haydon, S.R., Jayasuriya, M.D.A, and Finlayson, B.L. 1993. Water quality in mountain as forests: separating the impacts of roads from those of logging operations. Journal of Hydrology. Vol. 150: 459-480.

Gucinski, Hermann, Michael J. Furniss, Robert R. Ziemer, and Martha H. Brookes 2001. Forest Roads: A Synthesis of Scientific Information USDA Forest Service.

Hamlett, J.M., S.W. Melvin, R. Horton. 1989. Traffic and Soil Amendment Effects on Infiltration and Compaction. Soil and Water Division of the ASAE. p.6.

Hatchell, G. E., C.W. Ralston, and R.R. Foil. 1970. Soil disturbance in logging: Effects on soil characteristics and growth of loblolly pine in the Atlantic Coastal Plain. J. For. 68:772-775.

Haupt, H.F. 1959. Road and slope characteristics affecting sediment movement from logging roads. Journal of Forestry 57(5):329-332.

Herron, N.F. and Hairsine, P.B. 1998. A scheme for evaluating the effectiveness of riparian zones in reducing overland flow to streams. Australian Journal of Soil Resources Vol. 36: 583-698.

Hilliard, C. and S. Reedyk, 2003. Soil Texture and Water Quality. PFRA, Agriculture and AgriFood Canada. http://www.agr.gc.ca/pfra/water/soiltex_e.htm. Last visited 7/30/07.

Hood, S.M., S.M. Zedaker, W.M. Aust and D.W. Smith. 2002. Universal Soil Loss Equation (USLE)-Predicted Soil Loss for Harvesting Regimes in Appalachian Hardwoods. NJAF 19(2):53-58.

Huang, J., S.T., Lacey, and P.J., Ryan, 1996. Impact of Forest Harvesting on the Hydraulic Properties of Surface Soil. J. of Soil Science. Vol.161. No.2 pp.79-86.

Jones, Mark W. 2003. Thesis: Soil Compaction Caused By Timber Harvesting In Central Appalachian Hardwood Forests. Davis College of Agriculture, Forestry and Consumer Sciences at West Virginia University.

Klapproth, Julia C. 2000. Understanding the Science Behind Riparian Forest Buffers: Effects on Water Quality. Virginia Polytechnic Institute and State University. Virginia Cooperative Extension http://www.ext.vt.edu/pubs/forestry/420-151/420-151.html. Last visited 7/26/2007.

Kochenderfer, J.N., and J.W. Hornbeck, 1999. Contrasting Timber Harvesting Operations Illustrate the Value of BMPs. In Proceedings, $12^{\text {th }}$ central hardwood forest conference. March 28-February 2. Lexington, Kentucky.

Kochenderfer, J. N., Edwards P.J. and Wood F., 1997. Hydrologic Impacts of logging an Appalachian Watershed Using West Virginia's Best Management Practices. NJAF 14(4): 207218. 
Kochenderfer, J.N., and P.J. Edwards. 1991. Effectiveness of three streamside management practices in the central Appalachians. Pg. 688-700. Proceedings of the $6^{\text {th }}$ biennial southern silvicultural research conference. USDA Forest Service Gen. Tech. Rep. SE-70.

Kochenderfer, J.N. and J.D. Helvey. 1987. Using gravel to reduce soil losses from minimum standard forest roads. Journal of Soil and Water Conservation 42(1):46-50.

Kochenderfer, J.N., J.D. Helvey, and G.W. Wendel. 1987. Sediment Yield as a Function of Land Use in Central Appalachian Forests. In Proceedings of the Sixth Central Hardwood Forest Conference. Knoxville, Tennessee. pp. 497-502.

Kochenderfer, J. N., G.W. Wendel, and H.C. Smith. 1984. Cost of and soil loss on "minimumstandard forest roads constructed in the central Appalachians. Res. Pap. NE-544. Broomall, PA: U.S. Department of Agriculture, Forest Service, Northeastern Forest Experiment Station. 8p.

Kochenderfer, J.N., and J.D. Helvey. 1984. Some Effects of Forest Harvesting on Water Quality Fernow Experimental Forest, West Virginia. In Proceeding of the 1984 Penn State Forestry Issues Conference. J.O. Keller Conference Center. University Park, Pennsylvania. pp.44-51.

Kochenderfer, J.N., Wendel, G.W., 1980. Costs and Environmental Impacts of Harvesting Timber in Appalachia with a Truck-mounted crane. USDA Forest Service Res. Pap. NE-456. $9 \mathrm{p}$.

Laflen, J.M., L.J. Lane, and G.R. Foster. 1991. WEPP. A New Generation of Erosion Prediction Technology. J. Soil Water Conserv. 46(1): 34-38.

Lull, H. W. 1959. Soil compaction on forest and range lands. USDA For. Serv. Misc. Publ. No. 768. 33p. March 18, 2001Morgantown, WV 26505.

Lynch, J.A., Sopper, W.E., Corbett, E.S., and Aurand, D.W. 1975. Effects of management practices on water quality and quantity: the Penn State experimental watersheds. In Proceedings of a Symposium on Municipal Watershed Management. Northeastern Experiment Station, Broomall, Pa. USDA Forest Service General Technical Report NE-13, pp. 32-46.

Lynch, J.A., Corbett, E.S., and Mussallem, K. 1985. Best management practices for controlling non-point source pollution on forested watershed. Journal of Soil and Water Conservation Vol.40: 164-167.

Mattson, J., J. Baumgras, C. Blinn, and M. Thompson. 2000. Harvesting options for riparian areas. In: Verry E., J. Hornbeck, and A. Dollof (eds), Riparian Management in Forests of the Continental Eastern United States, Lewis Publishers, Washington, D.C.

McCool, D.K., Wischmeier, W.H., and Johnson L.C., 1982. Adapting the Universal Soil Loss Equation to the Pacific Northwest. P. 928-934 Transactions of the ASAE.

Meyer, L.D, and W.H. Wischmeier. 1969. Mathematical simulation of the processes of soil erosion by water. Trans. Am. Soc. Agric. Engrs. 12(6):754-758. 
Miller, Gerald and Michael Tidman, 2001. Impact of Soil Erosion on Soil Productivity. Integrated Crop Management. IC-486(1) pp.3-4.

Moehring, D.M., and I.W. Rawls. 1970. Detrimental effects of wet weather logging. J. For. 68: 166-167.

Norris, V. 1993. The use of buffer zones to protect water quality: a review. Water Resources Management Vol. 7:257-272.

Omakupt, M. 1989. Soil Erosion Mapping Using Remote Sensing Data and GIS. Proceedings of the 10th ACRS Nov. 23-29, 1989. Kuala Lumpur, Malaysia.

Patric, J.H. 1976. Soil erosion in the eastern forest. Journal of Forestry. Vol. 74:671-676.

Pope, P.E. 1991. Criteria For Evaluating Forestry Activities in Relation to Water Quality Management. Purdue University. http://www.ces.purdue.edu/extmedia/FNR/FNR-89.html. Last accessed 7/26/2007.

Rachael, J.M., and Karr, B.L., 1989. Effects of current harvesting practices on the physical properties of a loessal soil in west-central Mississippi P. 527-532 in Proc. Of the $5^{\text {th }}$ Bienn. South. Silvic. Res. Conf., Miller, J.E. (ed.) Memphis, TN.

Reid, Kevin D., Bradford P. Wilcox, David D. Breshears and Lee MacDonald. 1999. Runoff and Erosion in a Pinon-Juniper Woodland: Influence of Vegetation Patches. Soil Sci. Soc. of Am. J. Vol. 63:1869-1879.

Reinhart, K.G., A.R.Eschner, and G.R. Trimble Jr. 1963. Effects on Streamflow of Four Forest Practices in the Mountains of West Virginia. U.S. Forest Service Research Paper NE-I. 84p.

Reisinger, T. W., Powell D. B., Aust, W. M., and Oderwald, R. G. 1994. A postharvest evaluation of a mechanized thinning operation in natural loblolly pine. South. J. Appl. For. 18(1):24-28.

Renard, K.G., G. R. Foster, G.A. Weesies, and J.P. Porter. 1991. RUSLE: revised universal soil loss equation. J. Soil Water Conserv. 46(1): 30-33.

Rice, R.M.; Lewis, J. 1986. Identifying unstable sites on logging roads. In: 18th IUFRO World Congress, Division 1, Vol. 1. Forest environment and silviculture. Vienna, Austria: IUFRO Secretariat: $239-247$.

Riedel, Mark S. 2003. Collaborative research and watershed management for optimization of forest road best management practices. Proceedings of the 2003 International Conference on Ecology and Transportation. North Carolina State University, Raleigh, NC: pp.148-158.

SAS Institute Inc., SAS 9.1 for Windows, Cary, NC: SAS Institute Inc., 2004. 
Sheridan, Gary J., Philip J. Noske, Robyn K. Whipp, and Nimal Wijesinghe. The effect of truck traffic and road water content on sediment delivery from unpaved forest roads. Journal of Hydrological Processes. Vol. 20: pp. 1683-1699.

Shoop, S.A. 1995. Vehicle bearing capacity of frozen ground over a soft substrate. Can. Geotech. J. 32(3):552-556.

Soil Science Society of America 2007. Glossary of Soil Science Terms. (https://www.soils.org/sssagloss/index.php) Last Accessed 10/31/07.

Steinbrenner, E. C., and S.P. Gessel. 1955. The effect of tractor logging on physical properties of some forest soils in southwestern Washington. Soil Sci. Soc. Amer. Proc. 19:372-376.

Stone, D.M, and J.D. Elioff. 2000. Soil disturbance and aspen regeneration on clay soils: Three case histories. For. Chron. 76(5):747-752.

Stone, D.M. 2002. Logging Options to Minimize Soil Disturbance in the Northern Lake States. Northern Journal of Applied Forestry Vol. 19(3). Pp115-121.

Stuart, Gordon W. and P.J. Edwards. 2006. Concepts about Forests and Water. Northern Journal of Applied Forestry, Vol.23, No.1 (11-19).

Swift, L.W. Jr. 1984. Gravel and grass Surfacing Reduces Soil Loss From Mountain Roads. J. Forest Science 30(3): 657-670.

Swift, L.W. Jr. 1986. Filter Strip Widths for Forest Roads in the Southern Appalachians. SJAF 10: 27-34.

Swift, L.W., Jr. 1988. Forest access roads: design, maintenance, and soil loss. In: Swank, W.T.; Crossley, D.A., Jr. eds. Forest hydrology and ecology at Coweeta. Ecological Studies, Vol. 66. New York: Springer-Verlag: 313-324.

Turcoote, David E., Smith, C. Tattersall, and Federer, C. Anthony, 1991. Soil disturbance following whole-tree harvesting in North-Central Maine ${ }^{1}$. North. J. Appl. For. 8(2):68-72.

Talsma, T., and P.M. Hallman, 1980. Hydraulic conductivity measurement of forested catchments. Aust. J. Soils Res. 18:139-148.

Thompson, Amy and Jeff Stringer, 2003. Portable Skidder Bridges. The Kentucky Log Jam. Vol.7 No.3 pp.1-5.

Trimble, G.R. and R.S. Sartz. 1957. How far from a stream channel should a logging road be located. Journal of Forestry. Vol.55:339-341.

Tysdale, L.M., W.J. Elliot, C.H. Luce, and T. Black. 1997. Modeling Insloped Road Erosion Processes with the WEPP Watershed Model. Presented at the 1997 American Society of Agricultural Engineers Annual International Meeting, Paper no. 975014. St. Joseph, MI: ASAE. 
Ward, K. 1996. Timbering in West Virginia. Charleston Gazette. Sept. 8-11.

Weltz, M.A., K.G. Renard, and J.R. Simanton. 1987. Revised Universal Soil Loss Equation for Western Rangelands. P 104-111. In: Symp. Strategies for Classification and Management of Native Vegetation for Food Production in Arid Zones. USDA-GTR, RM-150. Tucson, Ariz.

WVDOF, 2005. West Virginia Silvicultural Best Management Practices for Controlling Soil Erosion and Sedimentation from Logging Operations. WVDOF-TR-05-3 (November 2005), Charleston, WV.

West Virginia Division of Forestry (WV DOF). 2002. Best Management Practices for Controlling Soil Erosion and Sedimentation from Logging Operations in West Virginia. WVDOF-TR-96-3 (August 2002), Charleston, WV.

West Virginia Division of Forestry. June 2001. Best Management Practices for Controlling Soil Erosion and Sedimentation from Logging Operations in West Virginia.

Wilson, J.P. 1986. Estimating the Topographic Factor in the Universal Soil Loss Equation for Watersheds. J. Soil and Water Conserv. May-June 1986. 179-184.

Wischmeier, W.H. 1976. Use and misuse of the universal soil loss equation. J. Soil and Water Cons. 31(1): 5-9.

Wischmeir, W.H., D.D. Smith, 1965. Predicting rainfall-erosion losses from cropland east of the Rocky Mountains - Guide for selection of practices for soil and water conservation.

Agricultural Handbook No. 282. 48 p.

Yoho, N.S. 1980. Forest management and sediment production in the south-a review. Southern Journal of Applied Forestry. Vol.4:27-36.

Zeigler, A.D., Sutherland, R.A. and Giambelluca, T.W. 2000. Partitioning total erosion on unpaved roads into splash and hydraulic components: the roles of interstrom surface preparation and dynamic erodibility. Journal of Water Resources Res. Vol. 36(9): 2787-2791. 


\section{APPENDICES}

\section{Appendix A: Sample Collection}

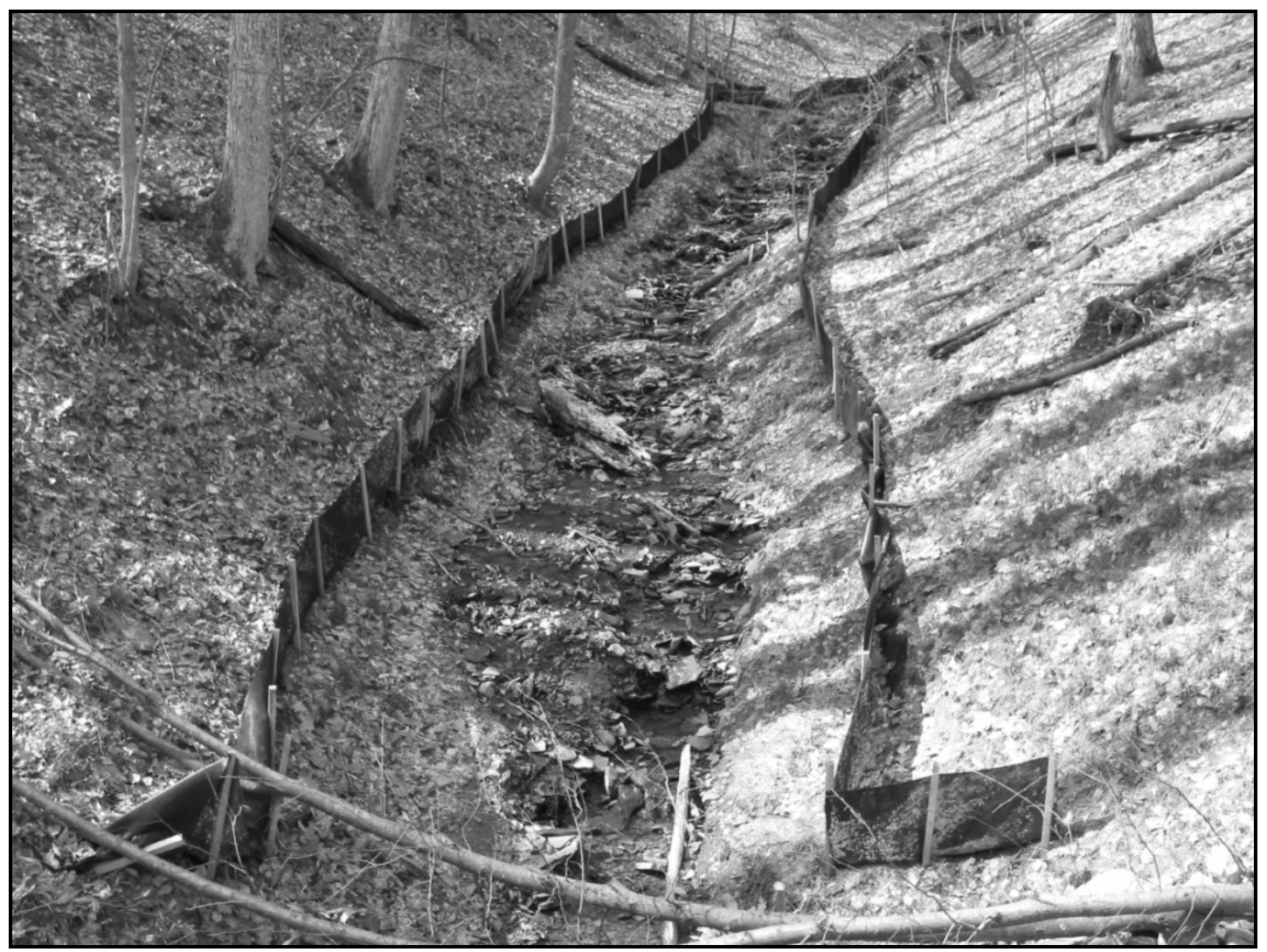

Figure A.1. Silt-fence installed around stream using Black Locust (Robinia psuedoacacia) posts and turf staples. 


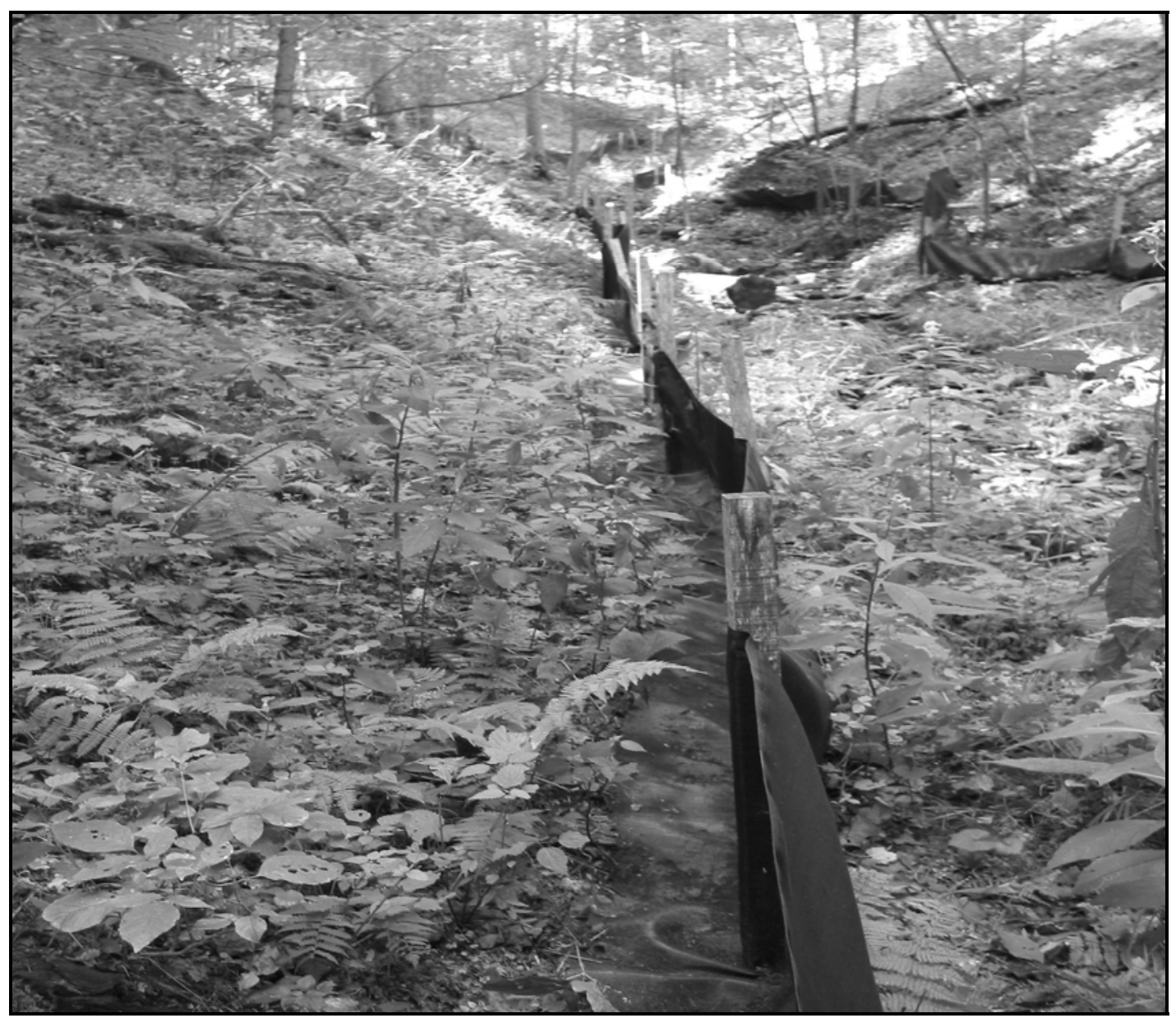

Figure A.2. Silt-fence folded up the hill to capture sediment from the adjacent hill-slopes. 


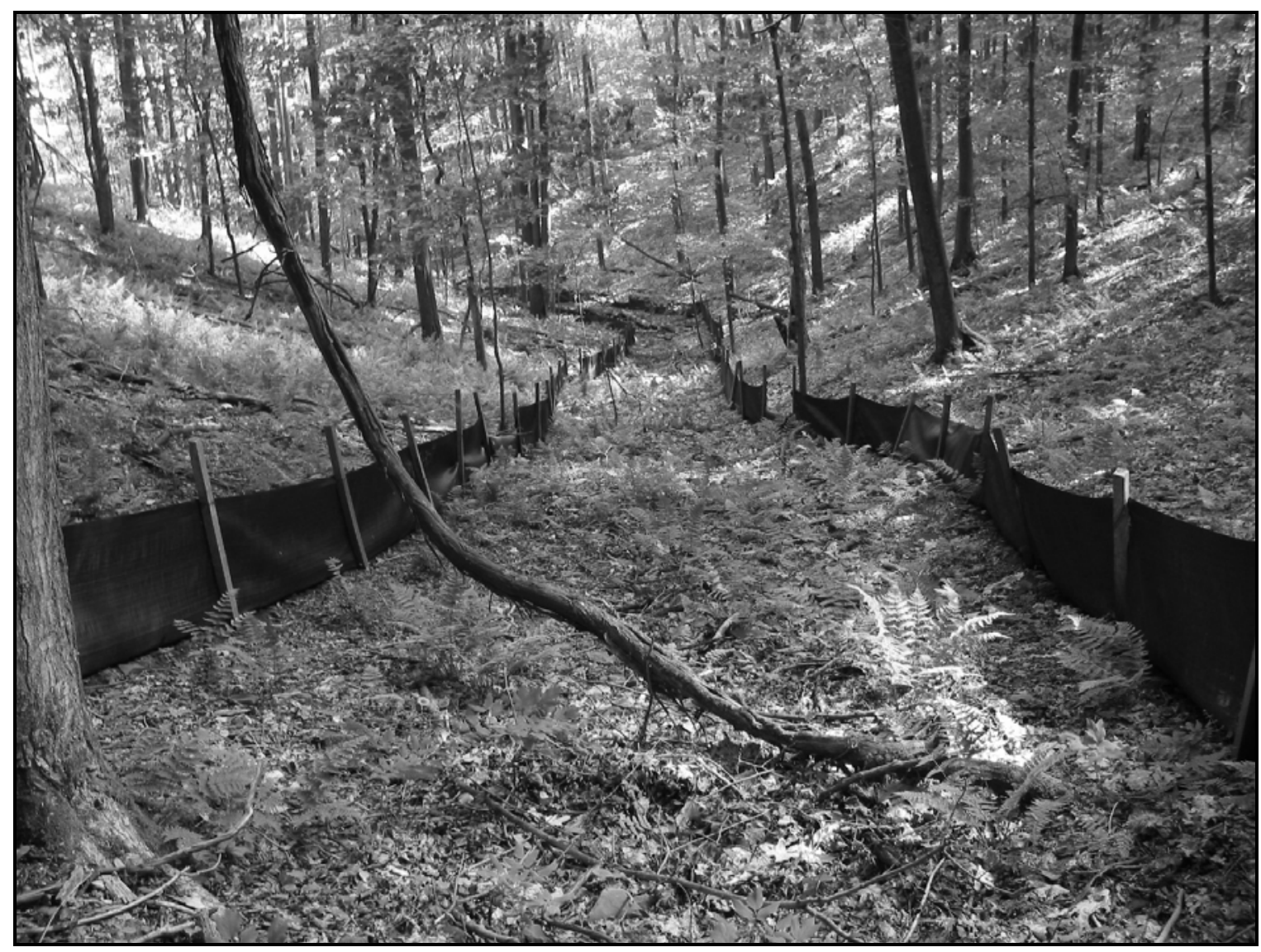

Figure A.3. Dry flow channel encompassed by silt-fence. 


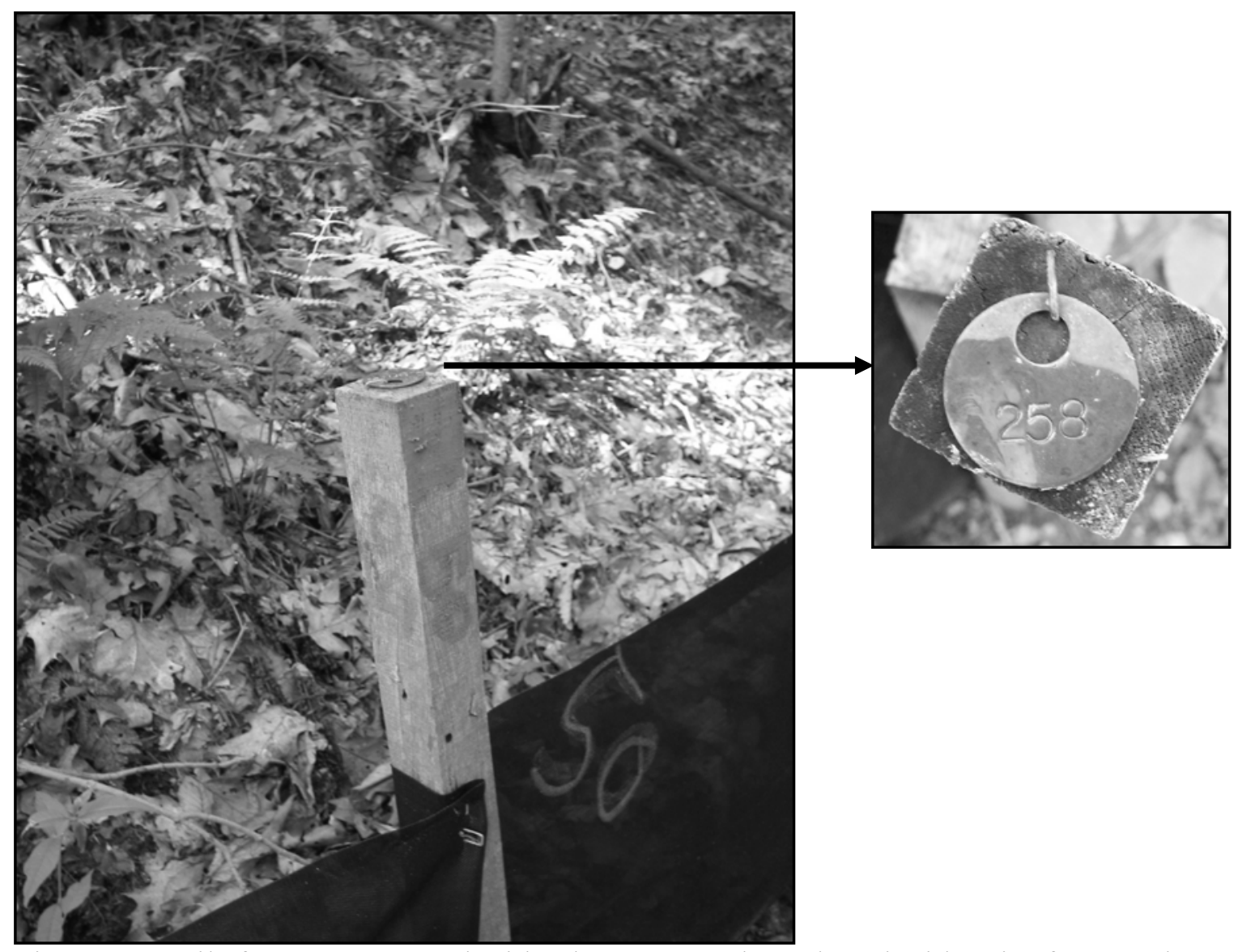

Figure A.4. Silt-fence post tagged with a brass tag and numbered with paint for sample site identification. 


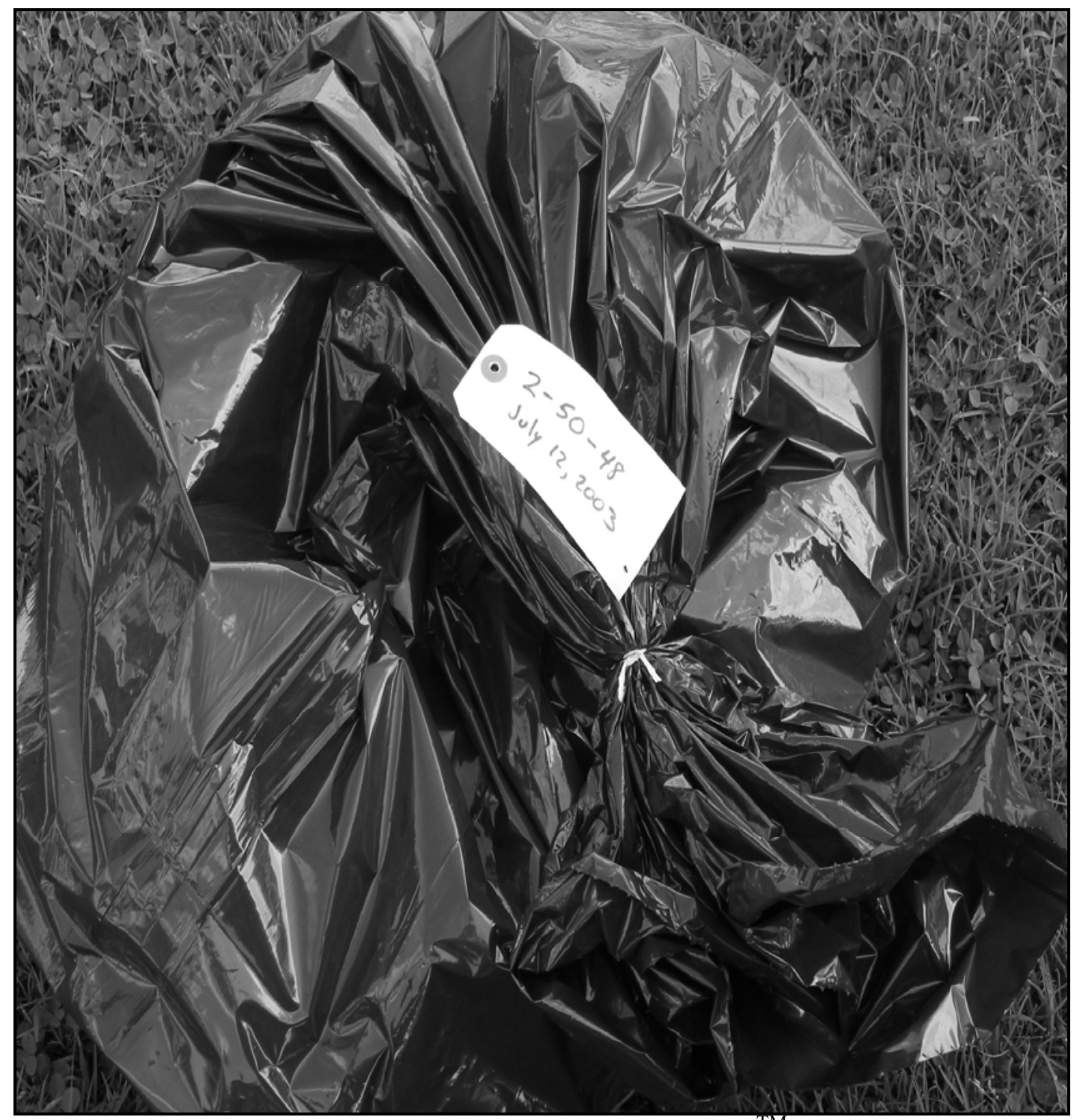

Figure A.5. Previously collected sample tagged with Tyvek $^{\mathrm{TM}}$ tag and sample labeled with location and collection date. 


\section{Appendix B: Sample Processing}

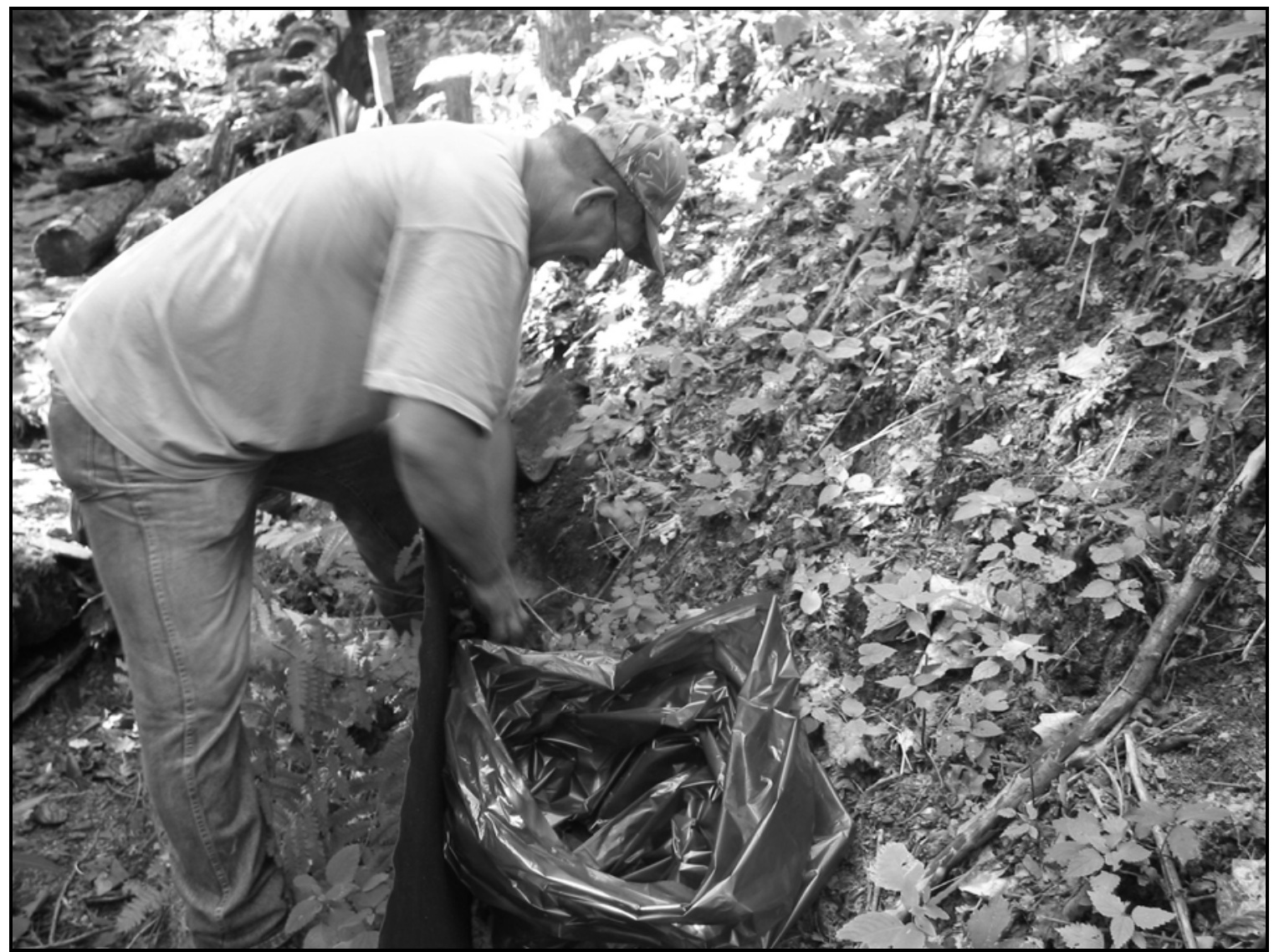

Figure B.1. Samples collected from silt-fences by hand and placed into trash bags for transport to the processing lab. 


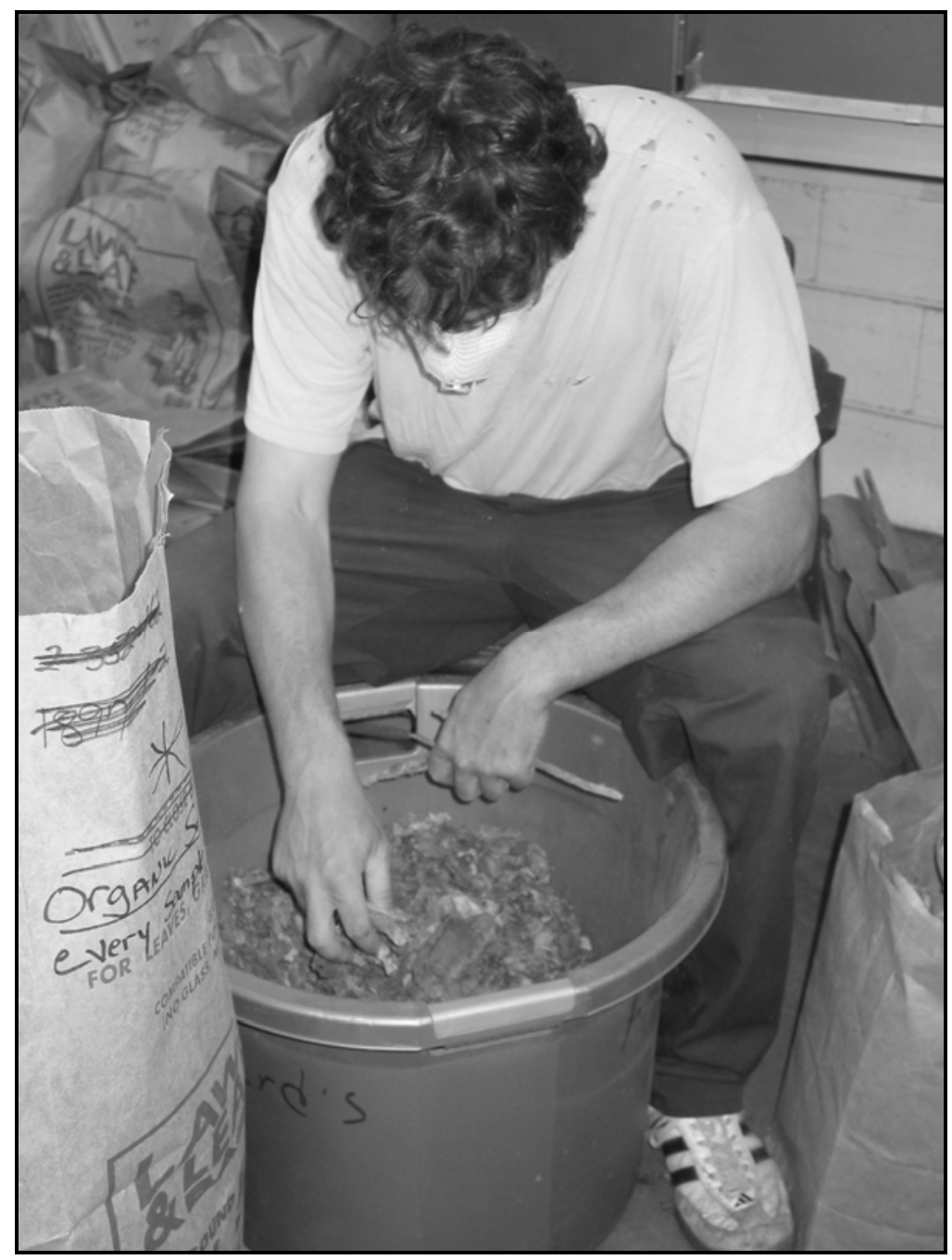

Figure B.2. Sample processing; removing organics from the sediment samples. 


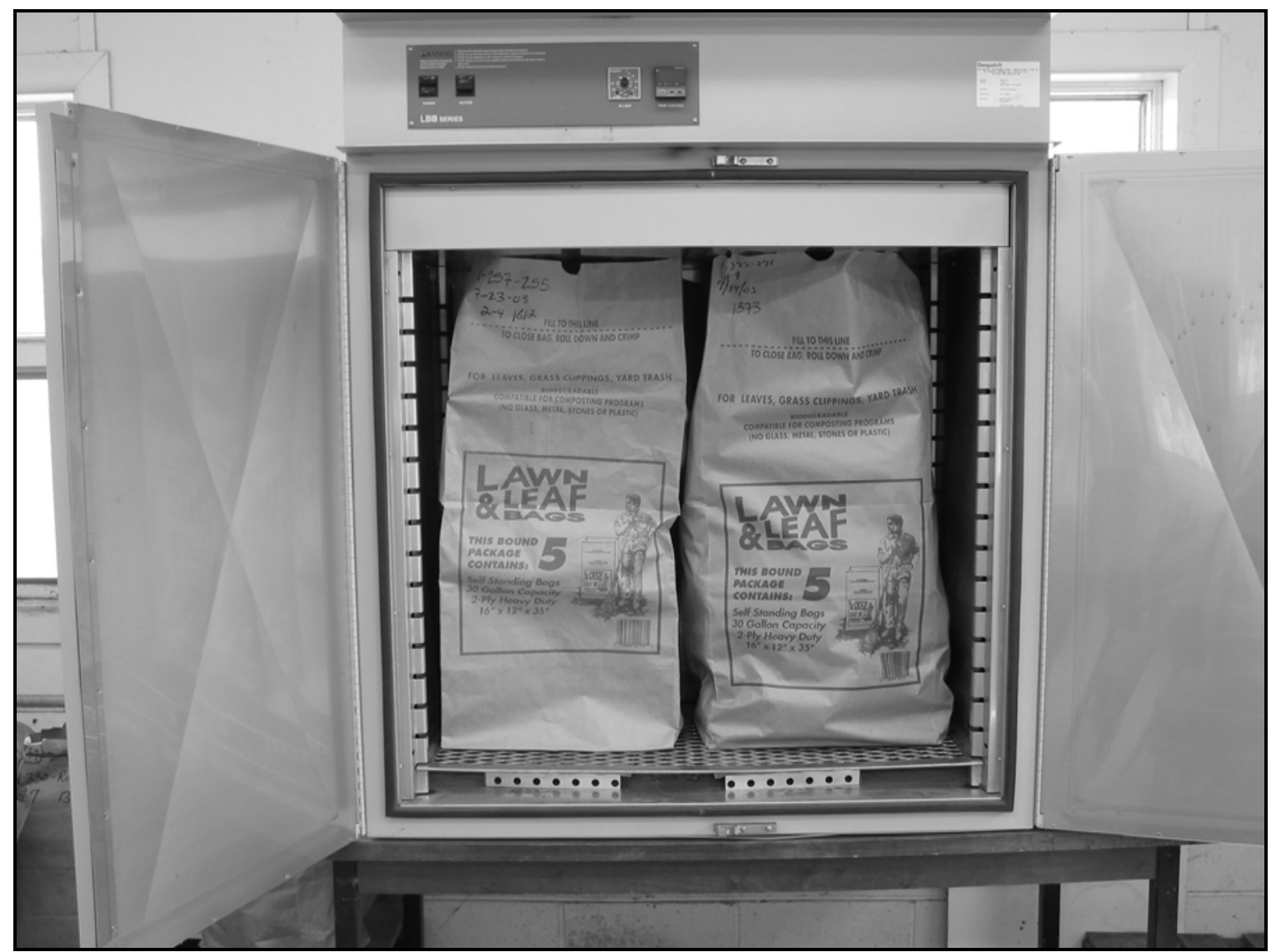

Figure B.3. Oven drying sediment samples in leaf bags. 


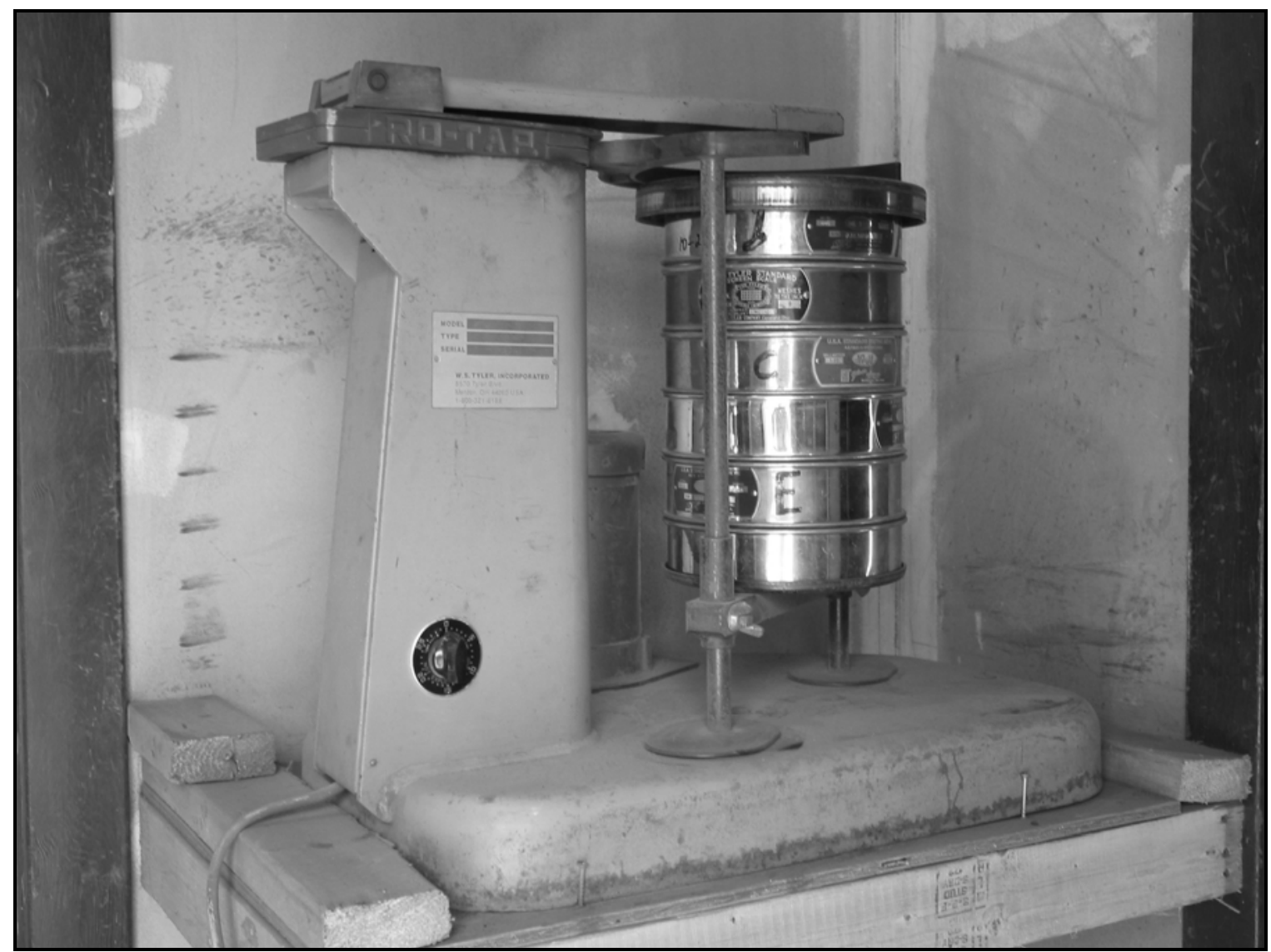

Figure B.4. Mechanical sieve used to sort sediment samples into size classes; the samples were then weighed and the data recorded into a Microsoft Excel workbook. 


\section{Appendix C: Site Surveying}
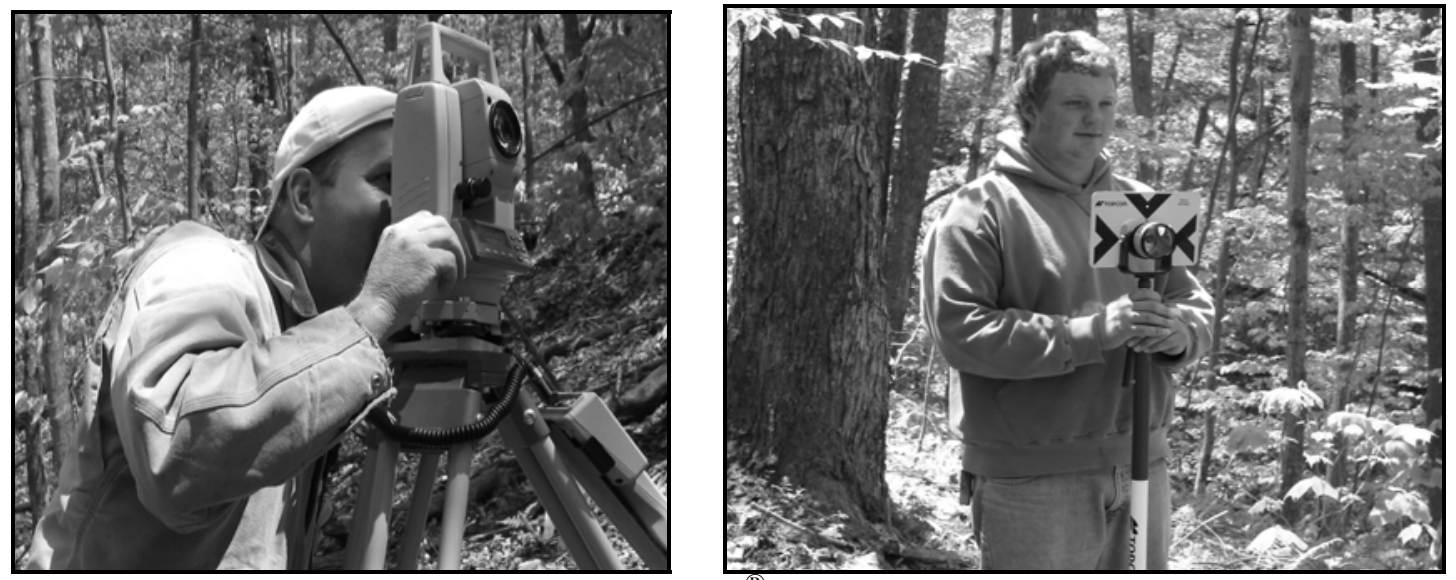

Figure C.1. Surveying instruments; TopCon ${ }^{(B)}$ Total Station and prism pole.

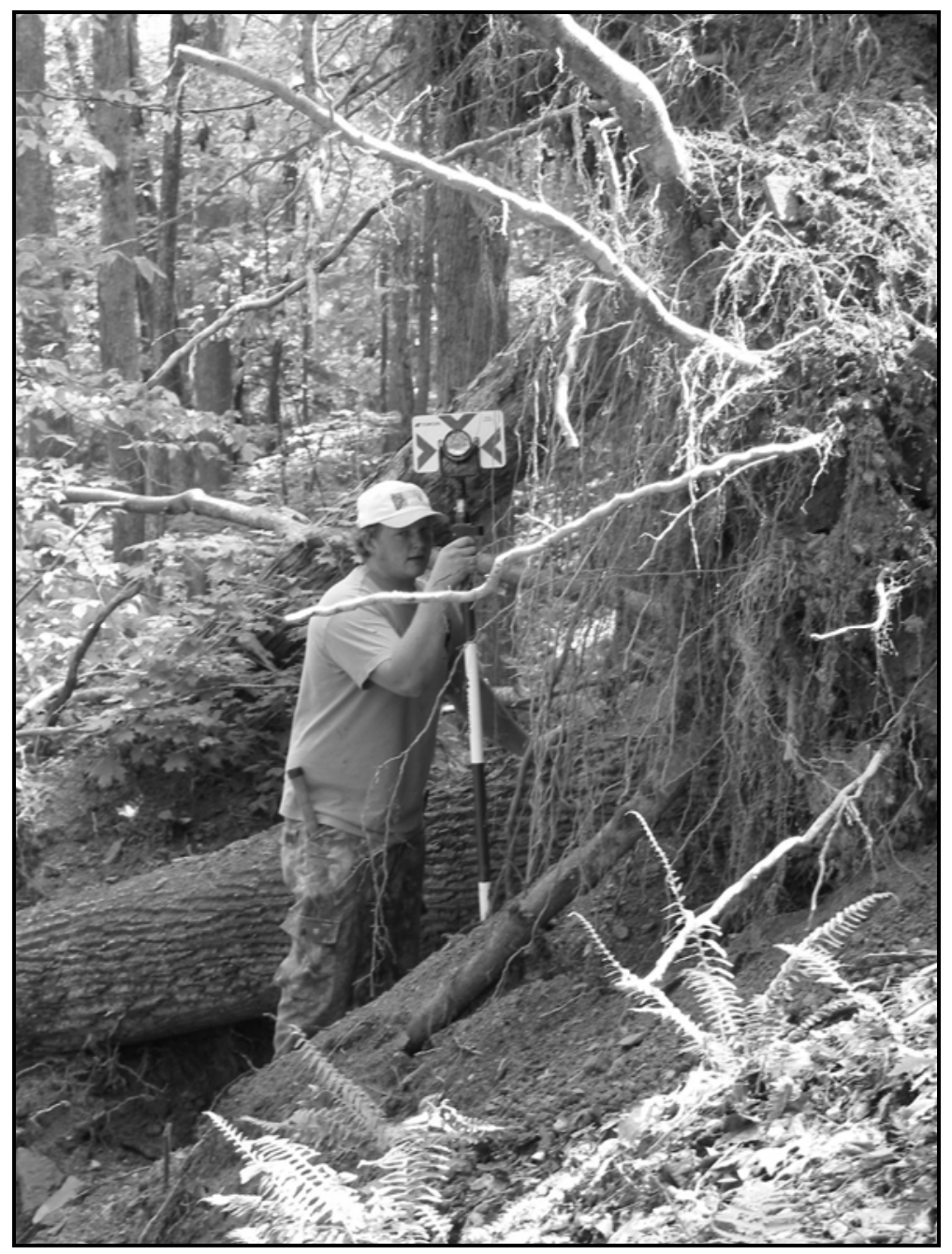

Figure C.2. Surveying the boundaries of a tree fall and the associated soil disturbance. 


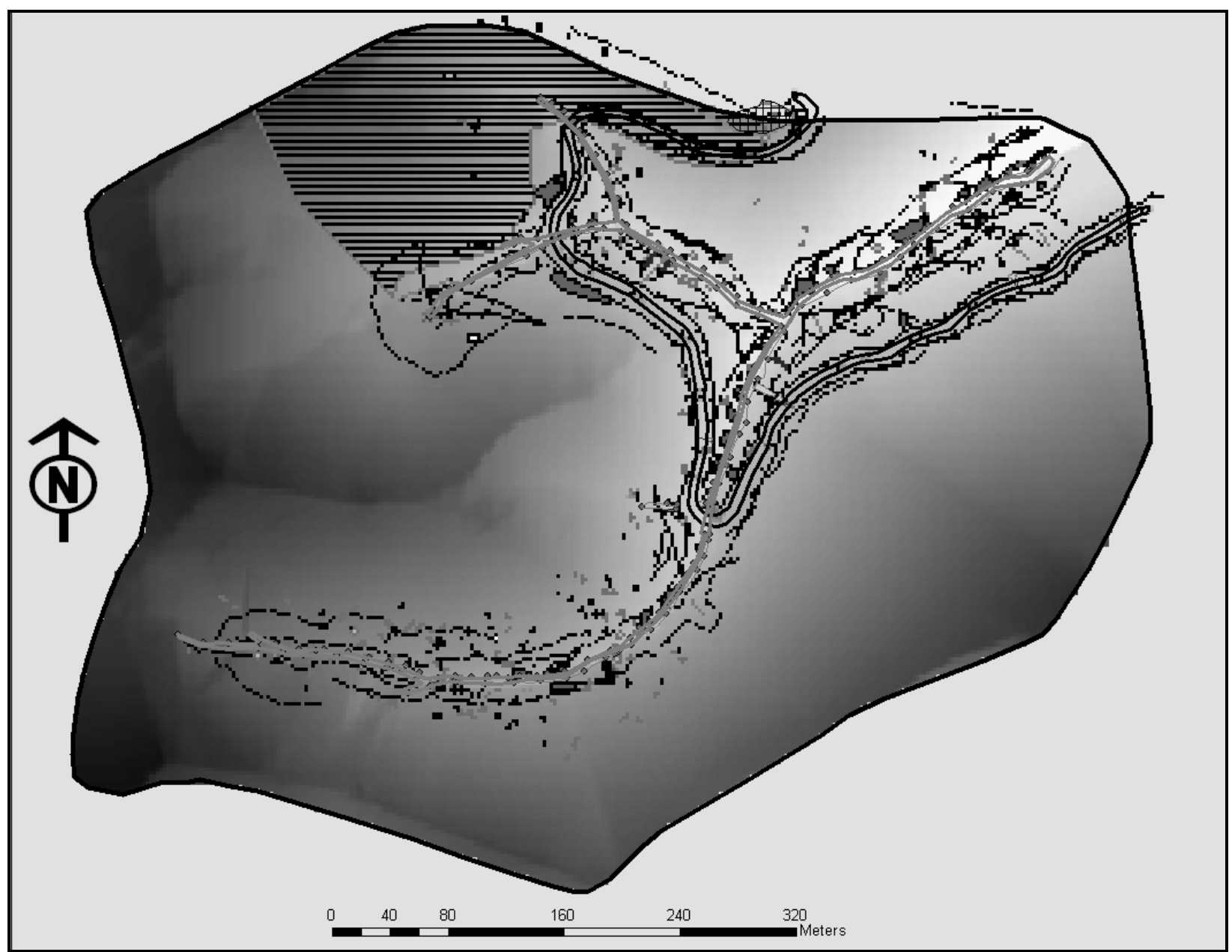

Figure C.3. All Surveyed Features Map (Treatment Watershed).

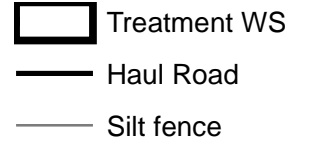

- $\quad$ Silt fence Posts

- Stream Channe

\#anding

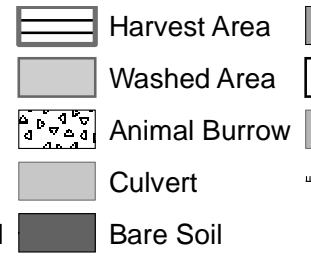

Bare Soi

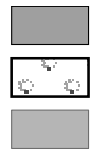

Cutbank

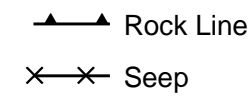

$\longrightarrow$ - Waterbars - Slip Line

--n-- Slope-break

Slopebreak Deertrail Combo , , Deer Trail

MUMM Slump Line

Landing Line 


\section{Appendix D: Haul Road Construction}

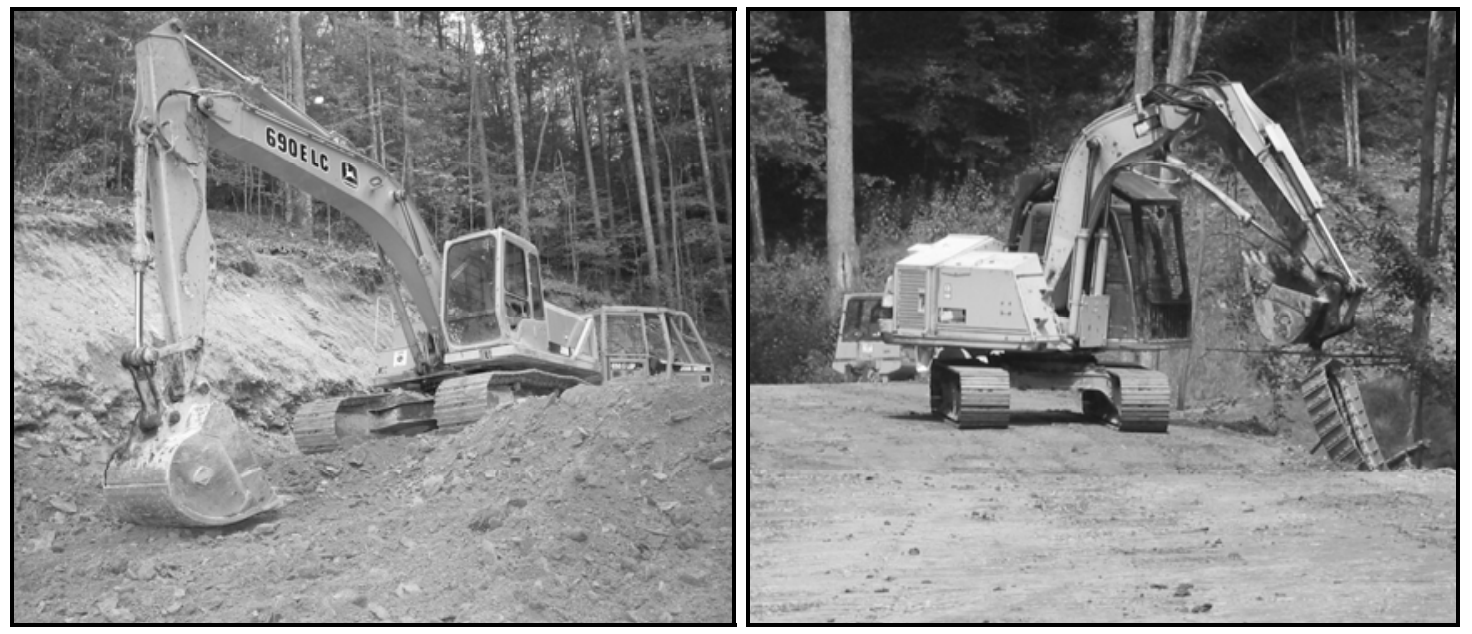

Figure D.1. John Deere 690 E LC Excavators used in road building process.
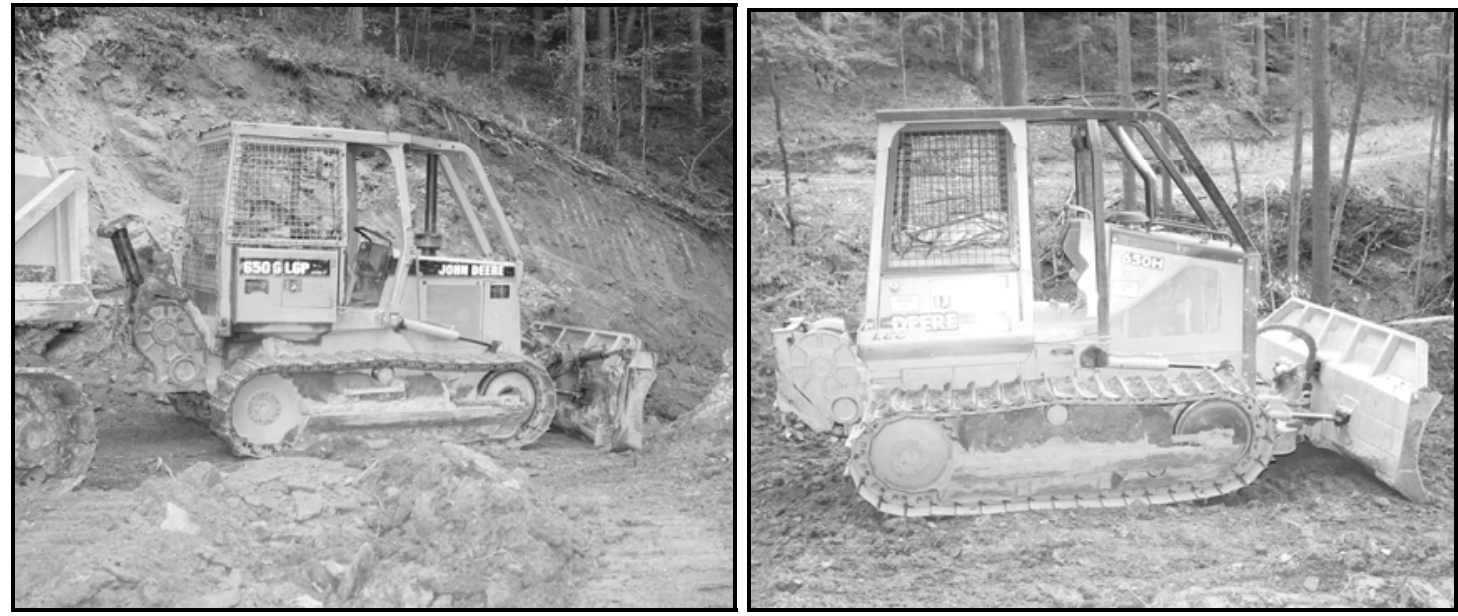

Figure D.2. John Deere 650G and 650H Bulldozers used in road building process.

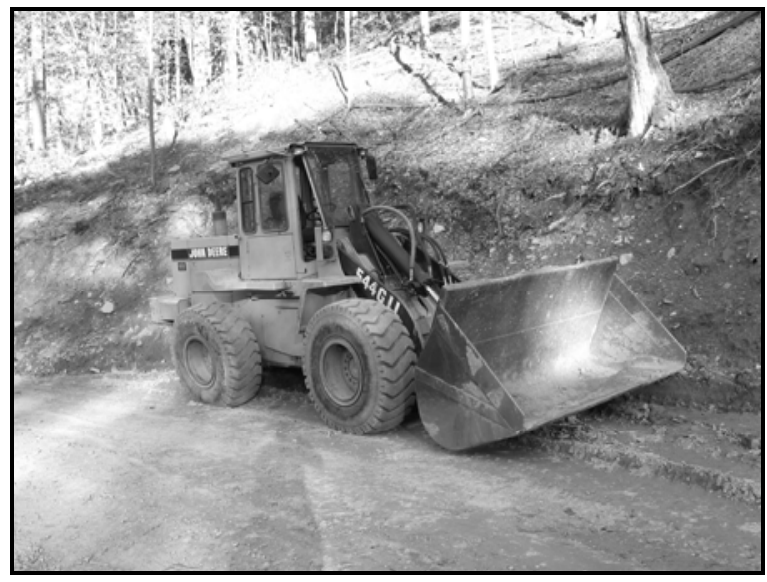

Figure D.3. A front-end loader was also used throughout the road building procedures. 


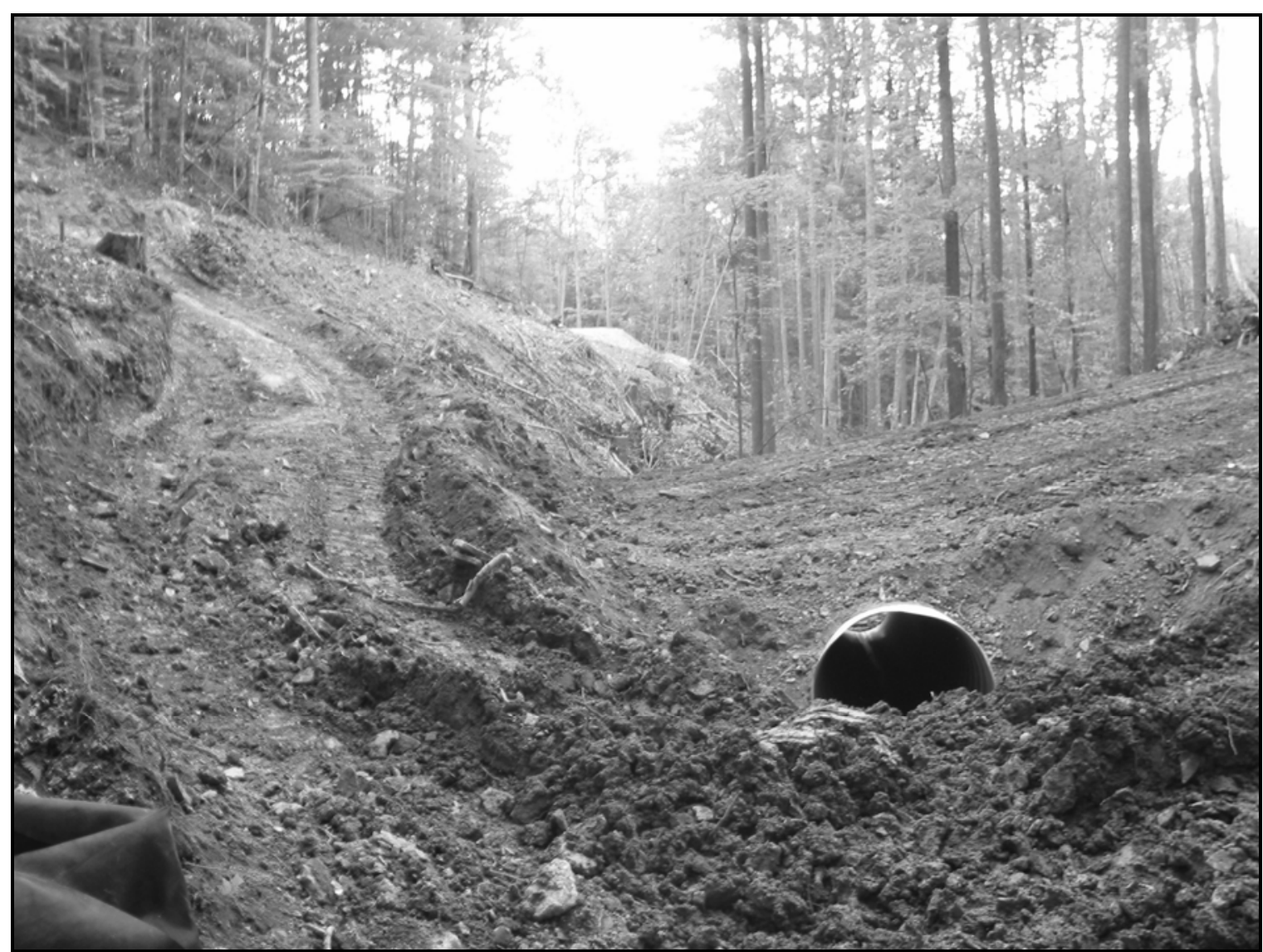

Figure D.4. Disturbance created during the construction of a permanent culvert-and-fill type stream crossing. 


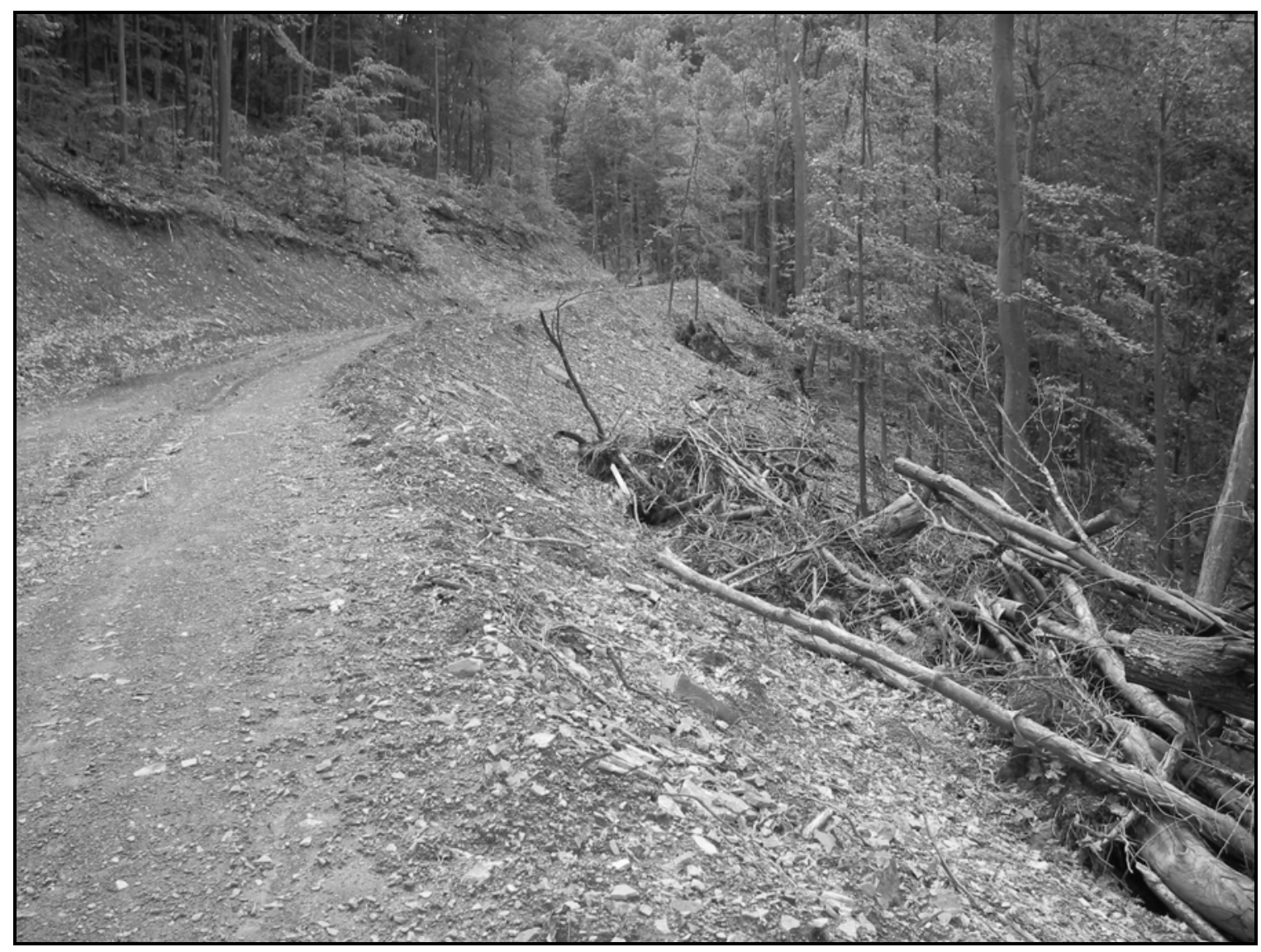

Figure D.5. Completed section of haul road in treatment watershed. 


\section{Appendix E: Spatial Analysis}

Each map in this appendix illustrates the treatment watershed. However, a similar map of each applicable type was constructed of the control watershed during the spatial analysis process.

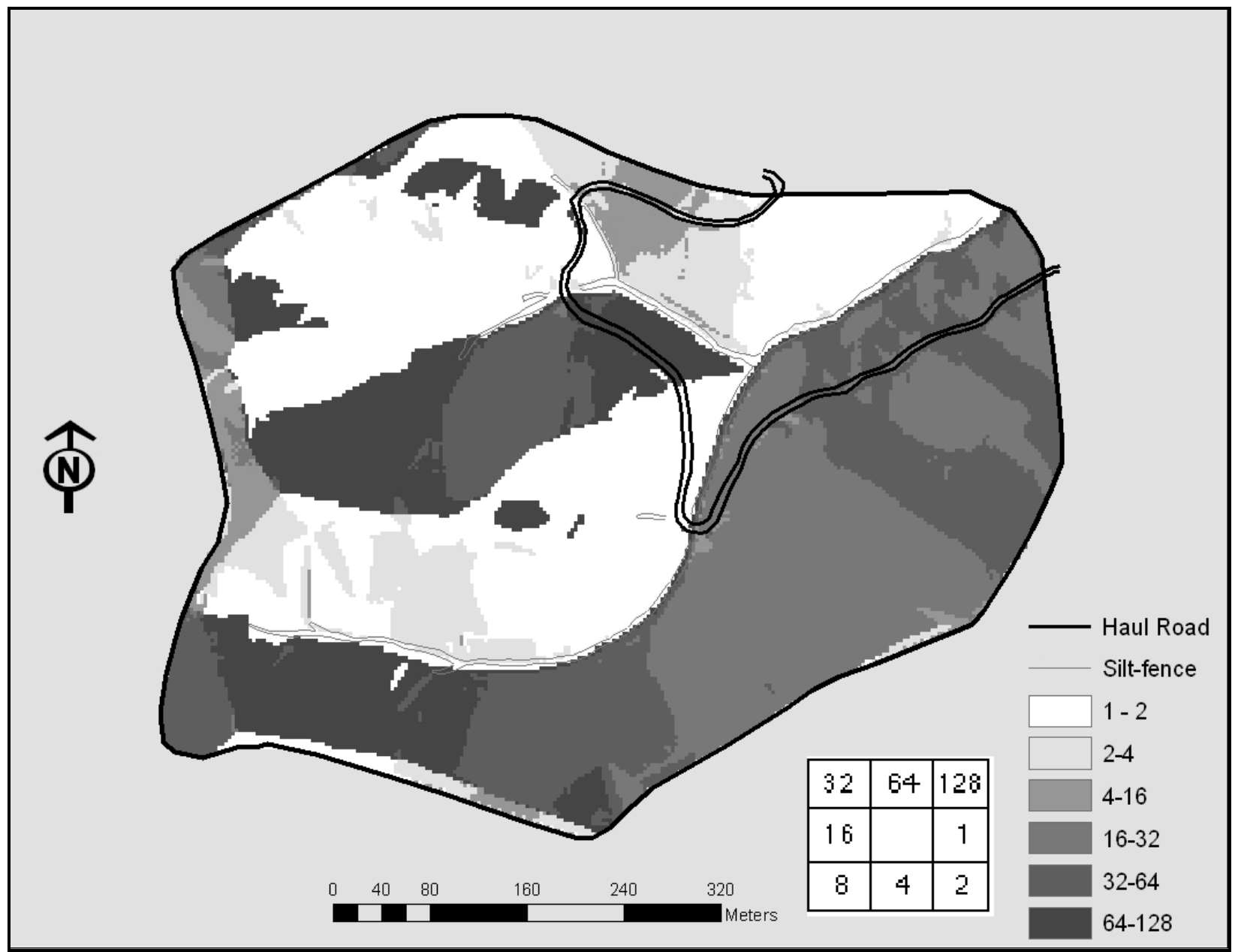

Figure E.1. Treatment watershed flow direction raster grid (FDR). 


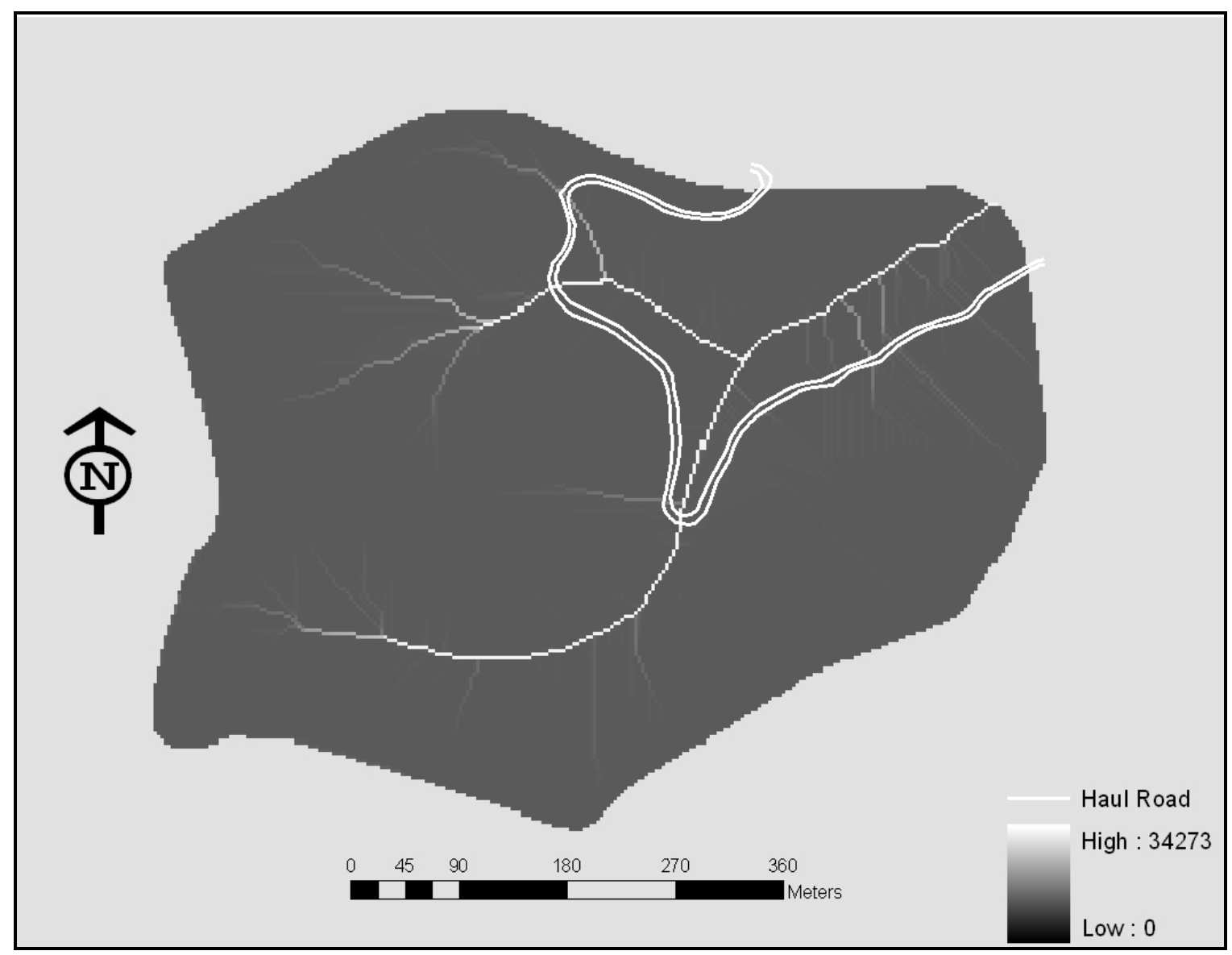

Figure E.2. Treatment watershed flow accumulation raster grid (FAC). 


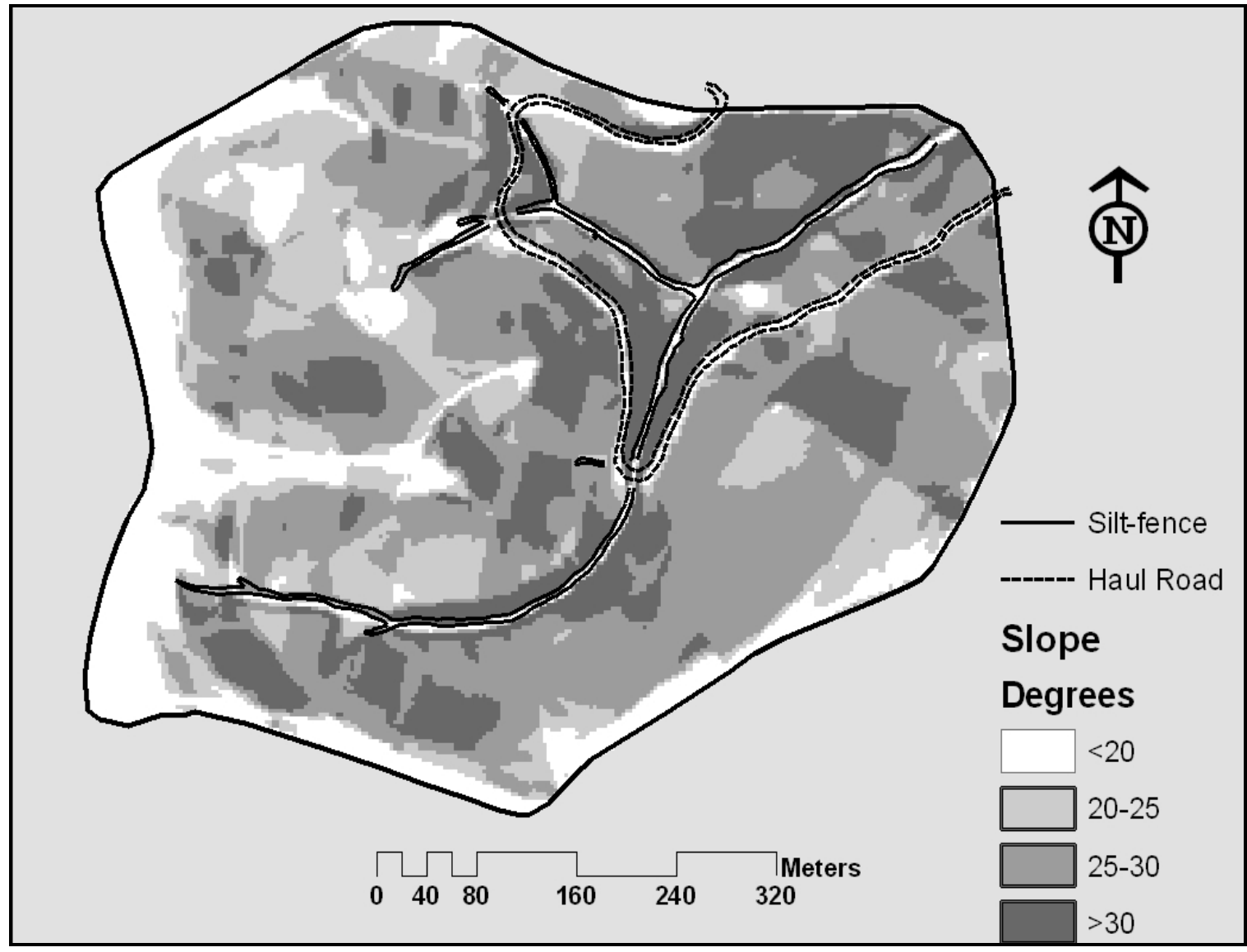

Figure E.3. Slope Map (Degrees). 


\section{Appendix F: Results Tables}

Table F.1. Means and standard deviations for the classes of the independent variables.

\begin{tabular}{|c|c|c|c|c|c|}
\hline \multirow[b]{2}{*}{ Variables } & \multirow[b]{2}{*}{ Classes } & \multicolumn{2}{|c|}{ Treatment Watershed } & \multicolumn{2}{|c|}{ Control Watershed } \\
\hline & & Mean & Standard Deviation & Mean & Standard Deviation \\
\hline \multirow[t]{4}{*}{ Year } & 2002 & 6464 & 13930.05698 & 585 & 1092.247 \\
\hline & 2003 & 11723 & 45244.61 & 363.5 & 552 \\
\hline & 2004 & 14310 & 44882.49 & 1368.5 & 3913 \\
\hline & 2005 & 5005 & 11837.47 & 682.6 & 1226.411 \\
\hline Slope Class & 20 & 6075.23 & 17201.21 & 646.80 & 1401.81 \\
\hline \multirow[t]{3}{*}{ Degrees } & 25 & 10315.70 & 25219.80 & 955.83 & 2364.84 \\
\hline & 30 & 6396.56 & 24539.90 & 1097.83 & 4360.52 \\
\hline & 35 & 15137.44 & 53206.14 & 415.37 & 448.88 \\
\hline Bare Soil Area & 4 & 11957.83 & 53180.70 & 472.79 & 616.07 \\
\hline \multirow[t]{4}{*}{ Square Meters } & 15 & 5912.56 & 7340.14 & 2041.06 & 4760.15 \\
\hline & 50 & 12575.09 & 57769.01 & 1167.38 & 1880.24 \\
\hline & 60 & 2132.13 & 42611.12 & 117.98 & 89.73 \\
\hline & 100 (missing) & 6927.36 & 21941.51 & 594.77 & 1612.39 \\
\hline \multirow[t]{5}{*}{ (Meters) } & 1 & 7713.12 & 13455.18 & 2468.12 & 5189.05 \\
\hline & 2 & 9387.28 & 15325.34 & 335.35 & 232.95 \\
\hline & 8 & 4288.35 & 9849.96 & 536.04 & 824.21 \\
\hline & 20 & 5967.12 & 15930.28 & 502.46 & 1474.37 \\
\hline & 100 (missing) & 6980.91 & 21939.06 & 594.77 & 1612.39 \\
\hline \multirow{6}{*}{$\begin{array}{l}\text { Distance to } \\
\text { Deer Trails } \\
\text { (Meters) }\end{array}$} & & & & & \\
\hline & 0.5 & 9438.92 & 26183.75 & 673.55 & 549.02 \\
\hline & 6 & 1911.49 & 2730.96 & 1320.48 & 2132.87 \\
\hline & 14 & 16229.16 & 56372.09 & 315.47 & 316.97 \\
\hline & 30 & 11709.13 & 24031.55 & 304.65 & 546.33 \\
\hline & 100 (missing) & 8851.60 & 31657.02 & 791.77 & 2430.77 \\
\hline
\end{tabular}




\begin{tabular}{|c|c|c|c|c|c|}
\hline Distance to & 15 & 24091.42 & 71613.07 & NA & NA \\
\hline \multirow[t]{4}{*}{ Road (Meters) } & 30 & 24482.56 & 77742.32 & NA & NA \\
\hline & 50 & 3283.46 & 4716.03 & NA & NA \\
\hline & 70 & 6756.66 & 18371.61 & NA & NA \\
\hline & 500 (missing) & 7229.04 & 19048.98 & NA & NA \\
\hline \multirow{7}{*}{$\begin{array}{l}\text { Distance to } \\
\text { Fill-Slopes } \\
\text { (Meters) }\end{array}$} & & & & & \\
\hline & 10 & 17956.80 & 70497.14 & NA & NA \\
\hline & 25 & 31411.25 & 89619.18 & NA & NA \\
\hline & 45 & 5287.97 & 12818.45 & NA & NA \\
\hline & 65 & 5457.63 & 15387.53 & NA & NA \\
\hline & 105 & 6684.06 & 14396.99 & NA & NA \\
\hline & 500 (missing) & 7849.08 & 21214.69 & NA & NA \\
\hline \multirow{6}{*}{$\begin{array}{l}\text { Distance to } \\
\text { WDEFs } \\
\text { (Meters) }\end{array}$} & 0.5 & 27491.37 & 82293.30 & NA & NA \\
\hline & 3 & 44679.53 & 44362.20 & NA & NA \\
\hline & 15 & 1977.56 & 5198.04 & 109.92 & 85.13 \\
\hline & 40 & 23191.23 & 93437.64 & NA & NA \\
\hline & 100 & 9456.63 & 19825.62 & 109.96 & 94.56 \\
\hline & 500 (missing) & 7061.30 & 21921.91 & 757.86 & 2181.33 \\
\hline \multirow{6}{*}{$\begin{array}{l}\text { Distance to } \\
\text { Slope-breaks } \\
\text { (Meters) }\end{array}$} & 2 & 7717.55 & 22701.53 & 1002.84 & 2289.53 \\
\hline & 6 & 3523.14 & 10558.98 & 701.97 & 1921.44 \\
\hline & 8 & 5407.93 & 9446.53 & 664.40 & 1086.61 \\
\hline & 11.5 & 13333.74 & 49130.94 & 617.19 & 970.58 \\
\hline & 15 & 12440.98 & 38216.48 & 504.71 & 1283.85 \\
\hline & 100 (missing) & 11353.24 & 38486.84 & 1336.88 & 4288.54 \\
\hline
\end{tabular}




\begin{tabular}{|c|c|c|c|c|c|}
\hline Distance to & 1 & 25293.33 & 40263.25 & NA & NA \\
\hline Wind-throws & 4 & 4668.68 & 6111.47 & 966.42 & 748.87 \\
\hline \multirow[t]{4}{*}{ (Meters) } & 9 & 4591.08 & 6595.19 & 183.79 & 256.87 \\
\hline & 25 & 9033.60 & 21965.56 & 994.74 & 3159.41 \\
\hline & 30 & 9617.06 & 16803.97 & 321.65 & 272.02 \\
\hline & 100 (missing) & 8282.87 & 38879.73 & 771.22 & 2195.64 \\
\hline \multicolumn{6}{|l|}{ Wind-throw } \\
\hline Soil & 3 & 5596.82 & 11825.36 & 351.08 & 509.74 \\
\hline Area (Square & 5 & 9901.54 & 19206.23 & 168.77 & 107.19 \\
\hline \multirow[t]{4}{*}{ Meters) } & 8 & 9292.02 & 23516.47 & 848.33 & 3163.12 \\
\hline & 13 & 10553.07 & 21690.13 & 411.88 & 247.72 \\
\hline & 40 & 17259.81 & 34403.77 & 966.42 & 748.87 \\
\hline & 100 (missing) & 8282.87 & 38879.73 & 771.22 & 2195.64 \\
\hline \multirow[t]{4}{*}{ Moisture Class } & (Dry) -1.92 & 7194.92 & 19182.70 & 1378.99 & 1836.25 \\
\hline & (Moist) 1.07 & 8548.37 & 37790.52 & 629.93 & 2494.56 \\
\hline & (Wet) 7.66 & 12786.07 & 28894.25 & 428.45 & 686.49 \\
\hline & Missing (500) & 4617.83 & 4649.70 & NA & NA \\
\hline
\end{tabular}




\section{Appendix G: Sources of Soil Movement and Sediment Material}

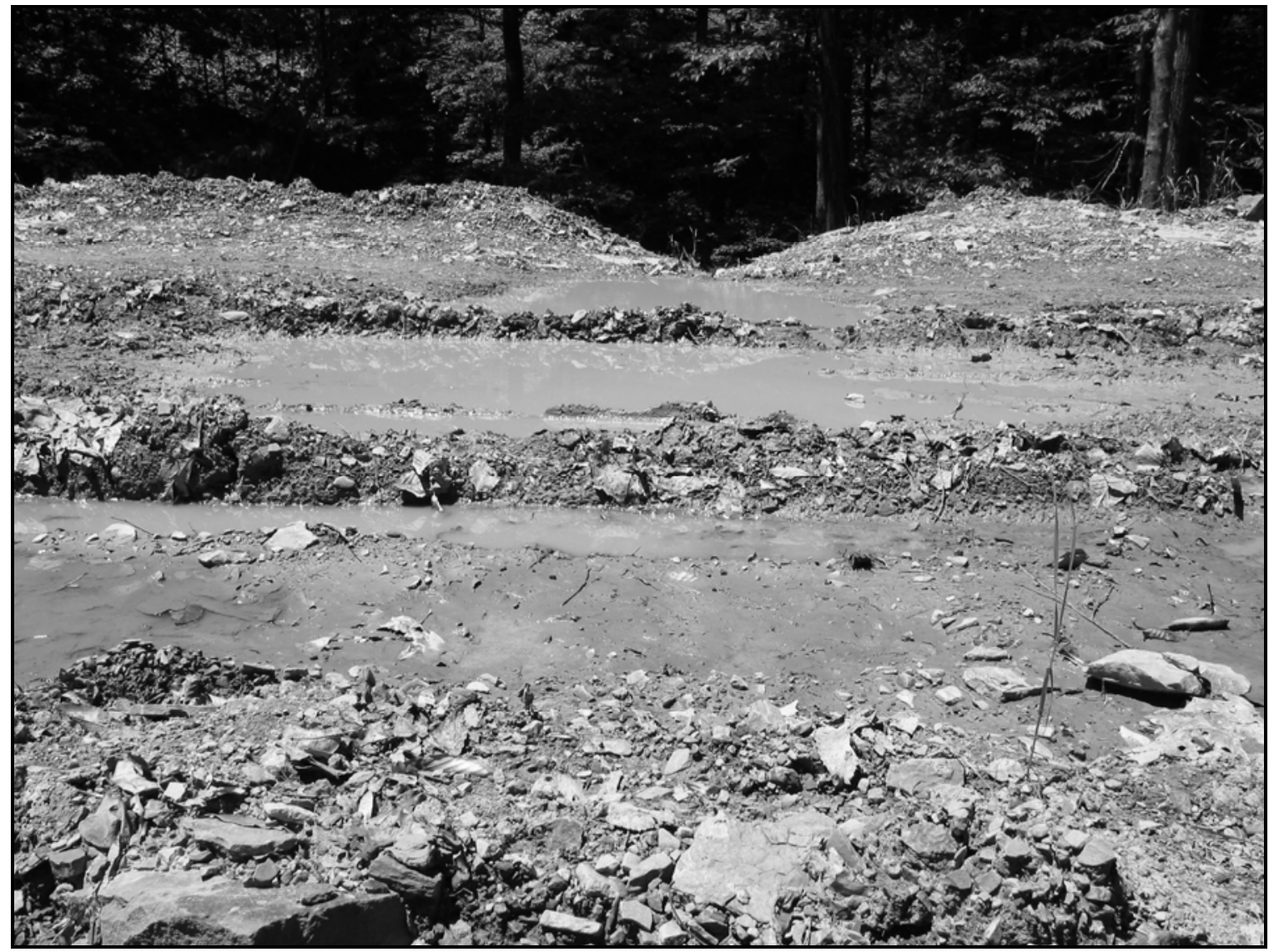

Figure G.1. Rutting and low spot in the haul road accumulating water and sediment material; indication of poor drainage. 


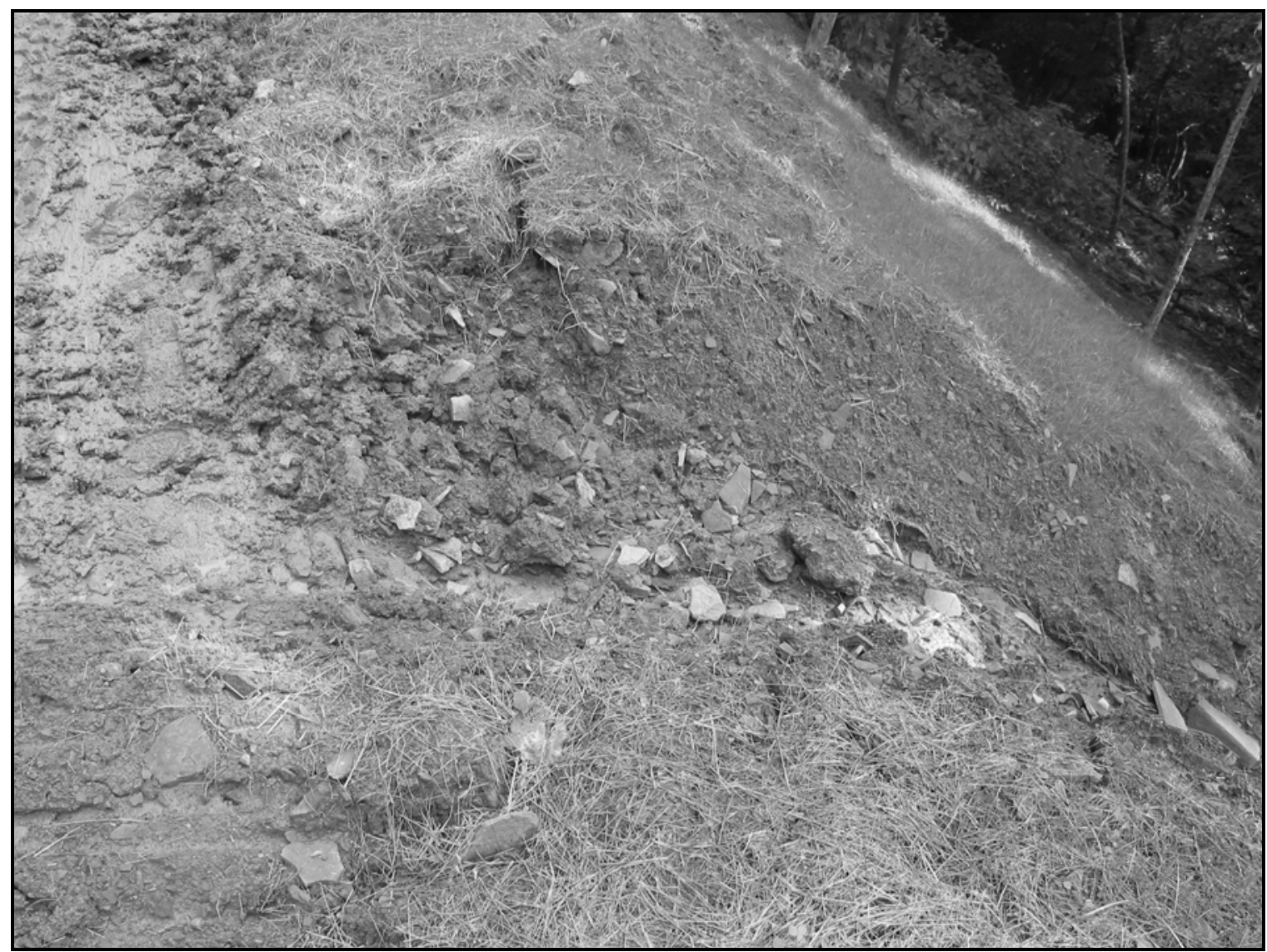

Figure G.2. Erosion of the fillslope as a result of water accumulation on the road surface. 


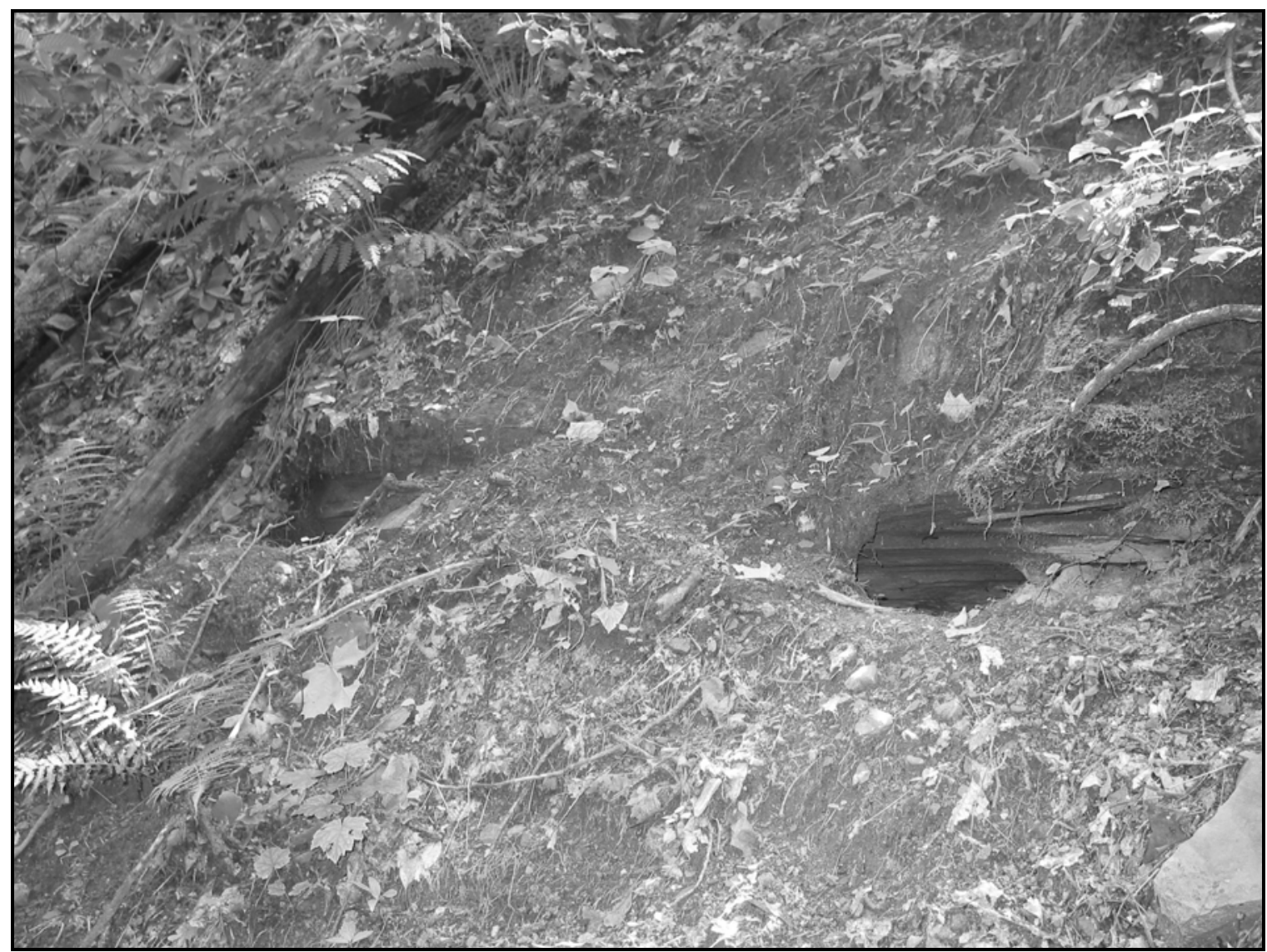

Figure G.3. Animal burrows expose soil making it more susceptible to the effects of erosion. 


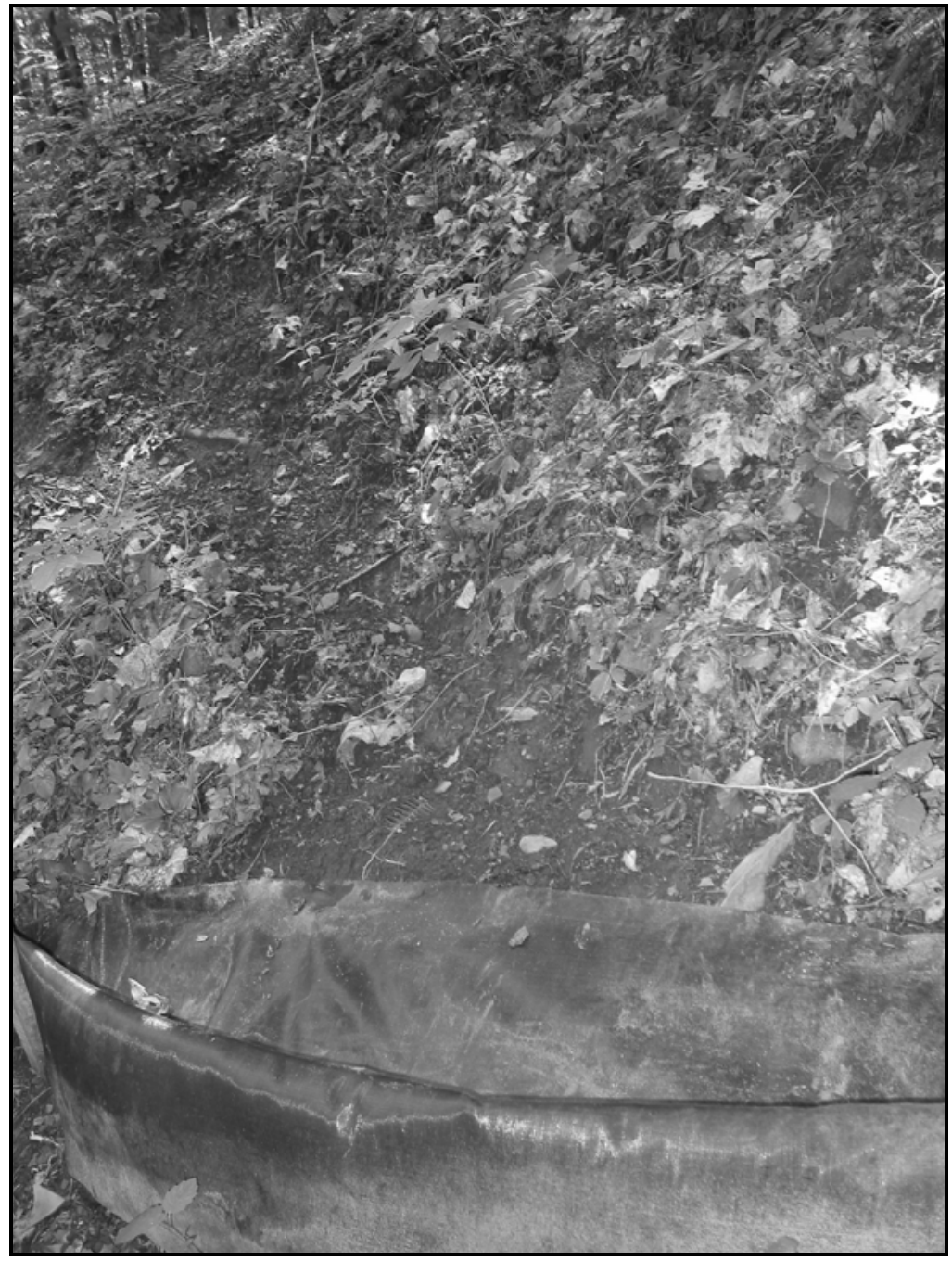

Figure G.4. Animal trails create areas of bare soil which are more susceptible to the effects of erosion due to the lack of vegetative protection. 


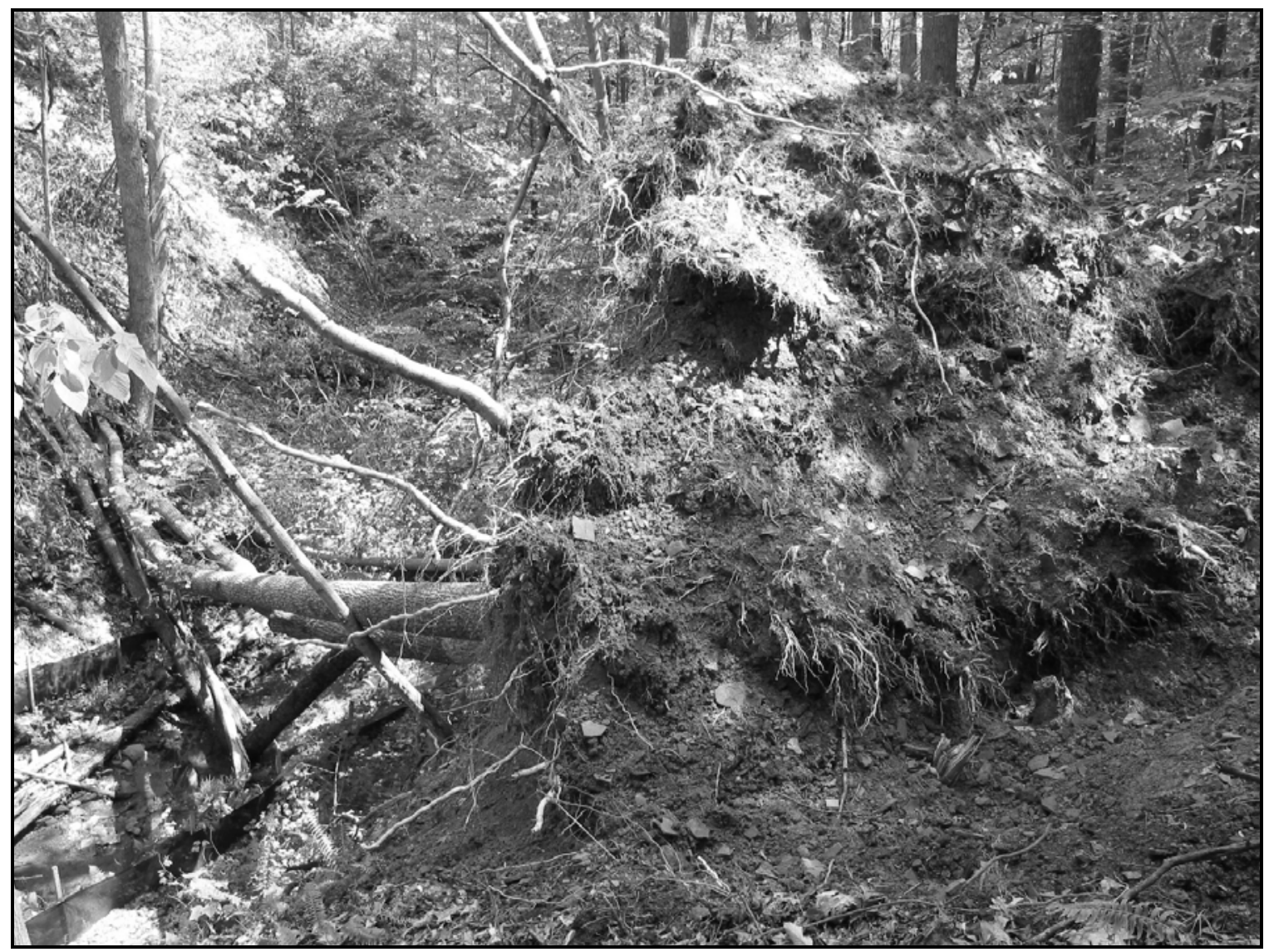

Figure G.5. Tree falls create vast quantities of disturbed, exposed soil which is easily transported to adjacent streams if not stabilized. 


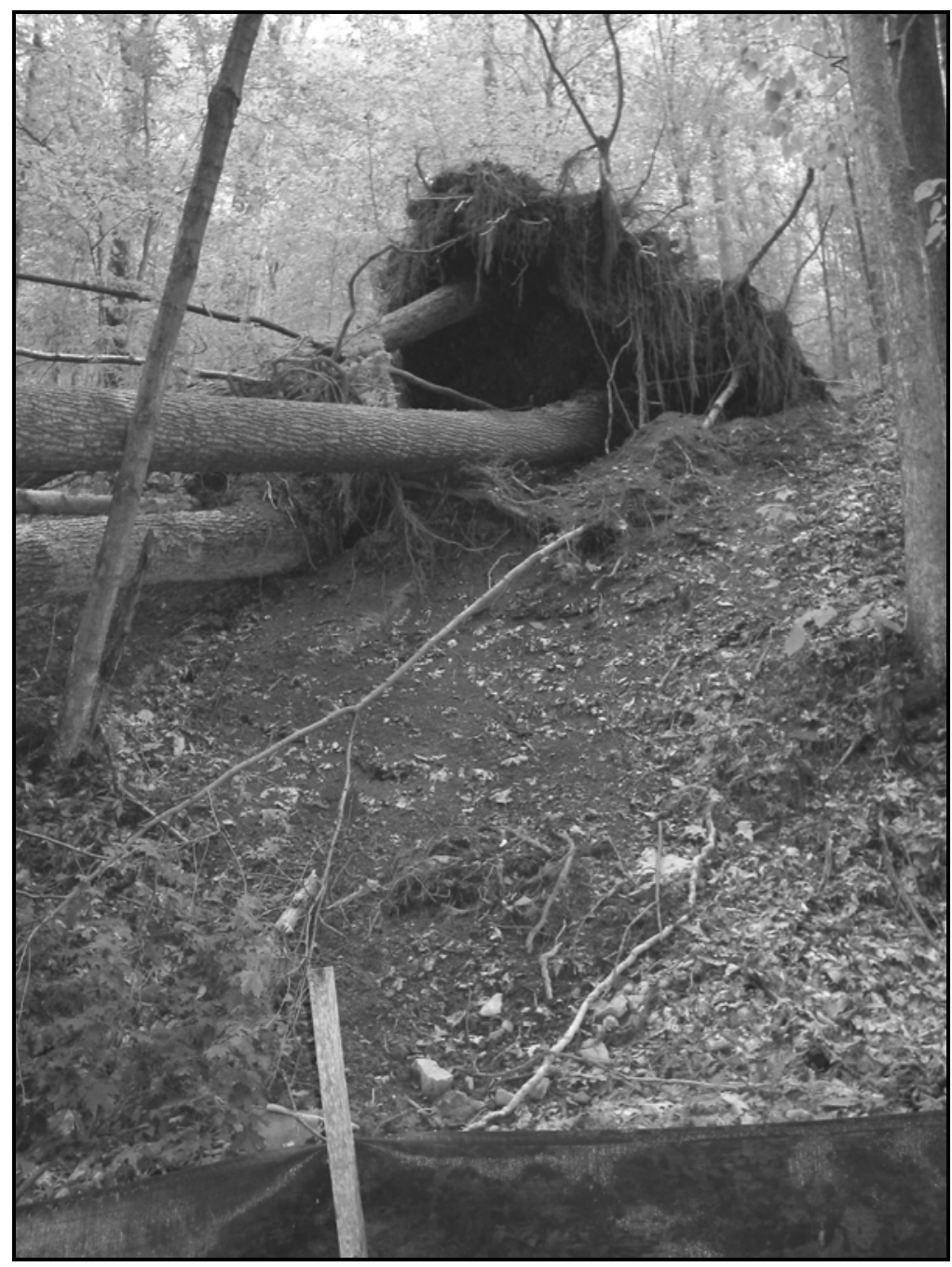

Figure G.6. Tree falls contribute large quantities of soil from rather small areas. 


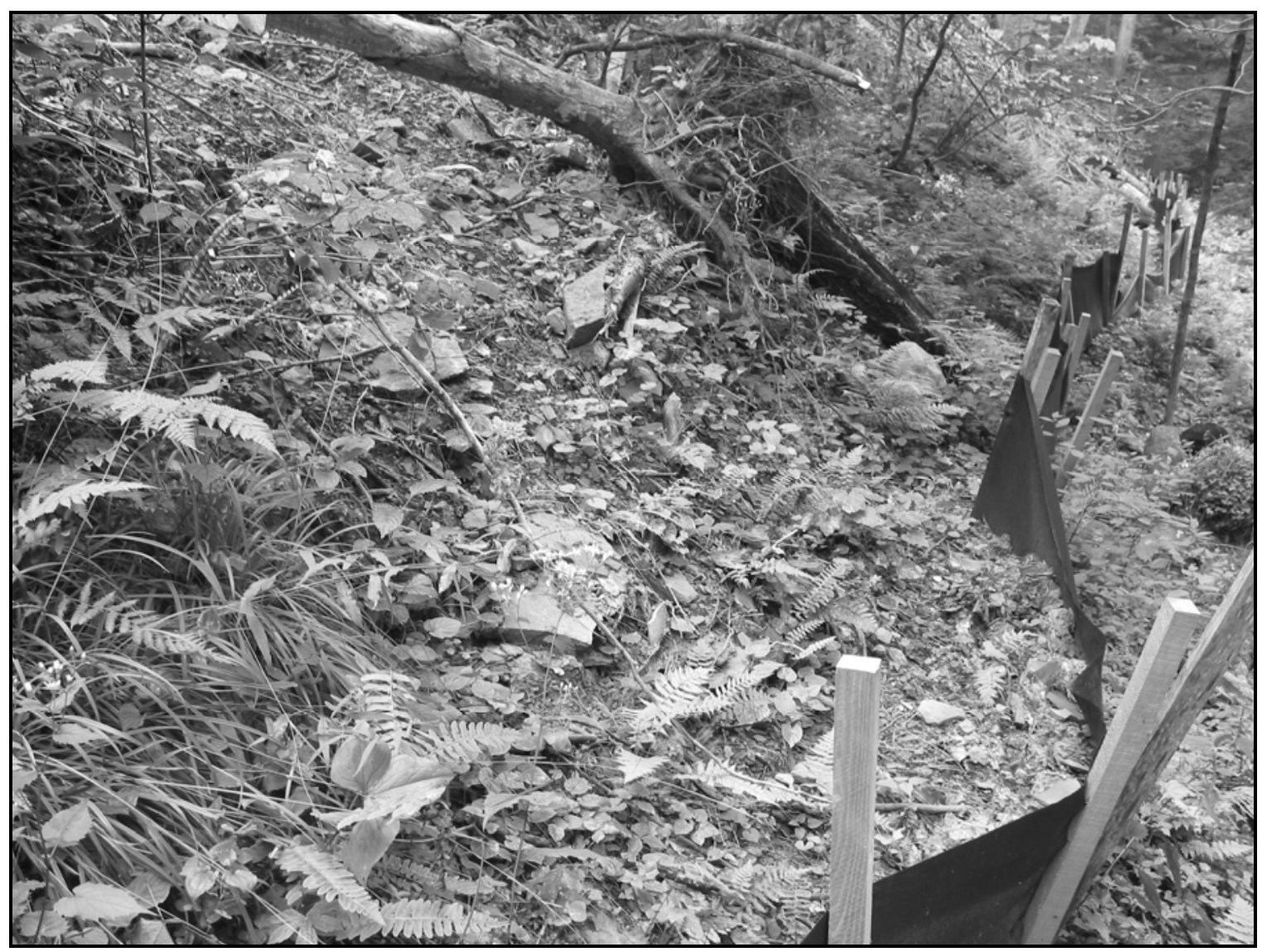

Figure G.7. Debris slides move immense quantities of material down the slopes all at once. 


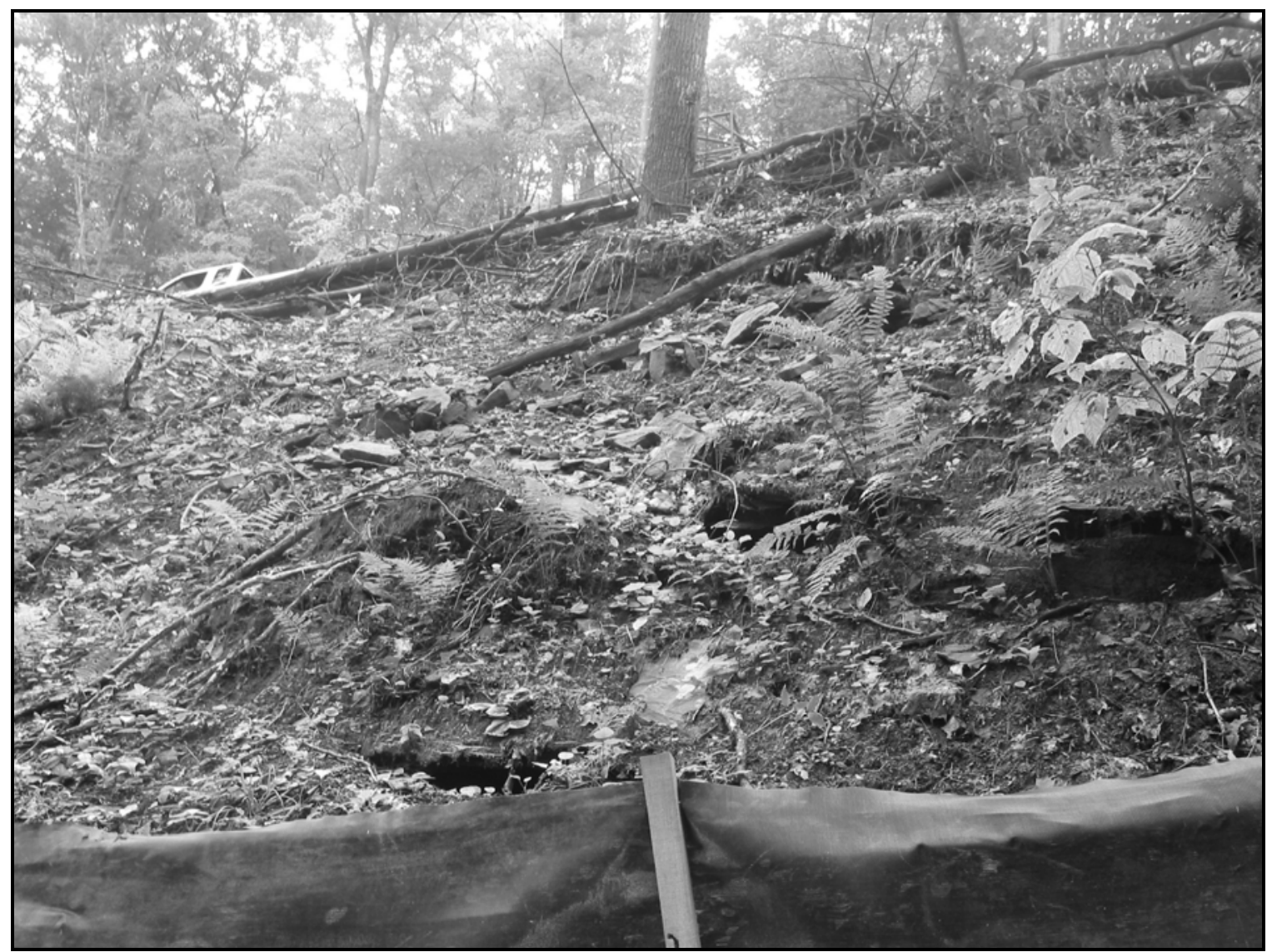

Figure G.8. Steep fill-slopes and embankments allow material to move easily down the slope due to the force of gravity and water. 


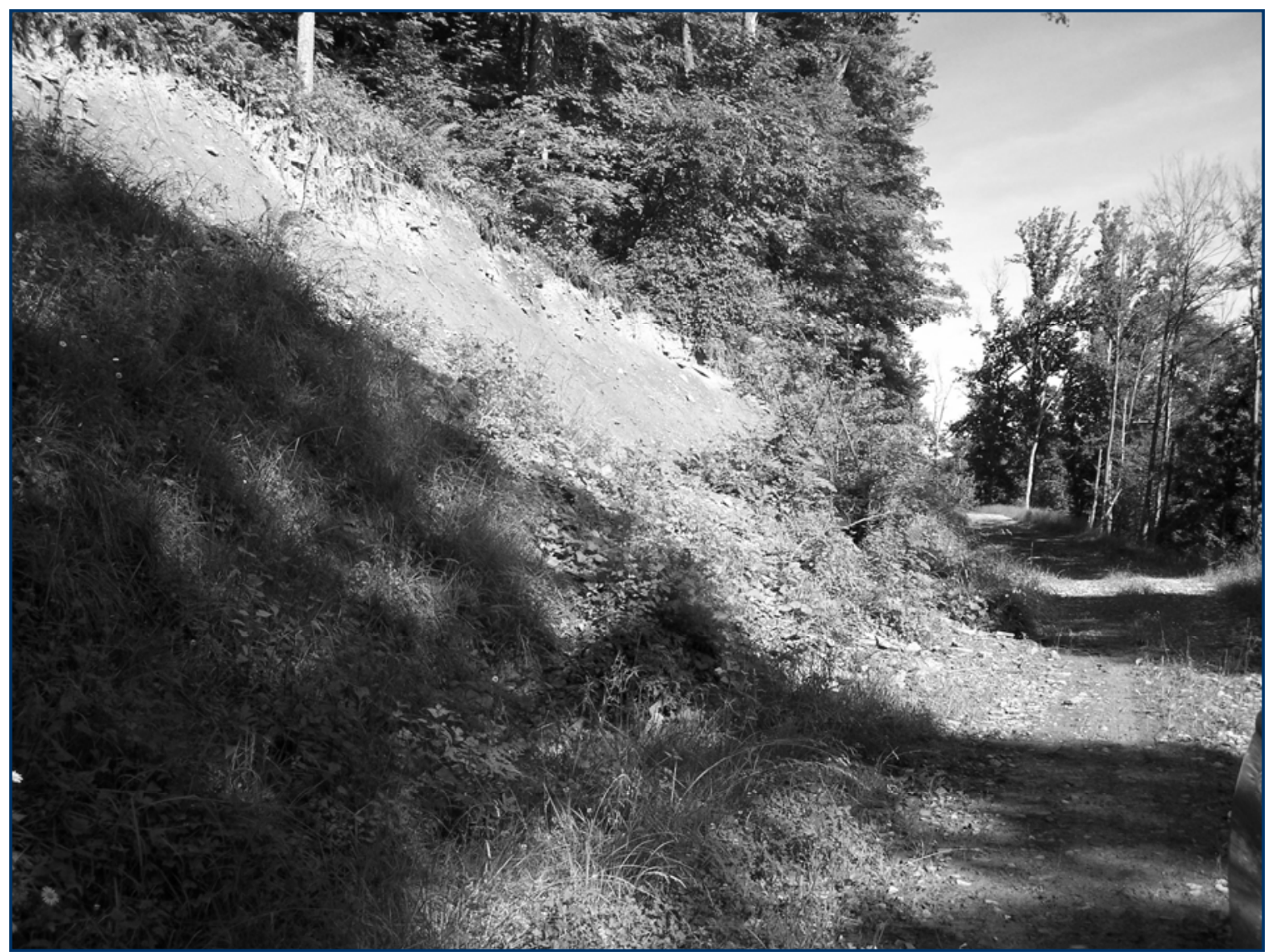

Figure G.9. Cutslope slip above road in treatment watershed. These areas can contribute to road and ditch line erosion as a result of blocking water control structures such as culverts. 


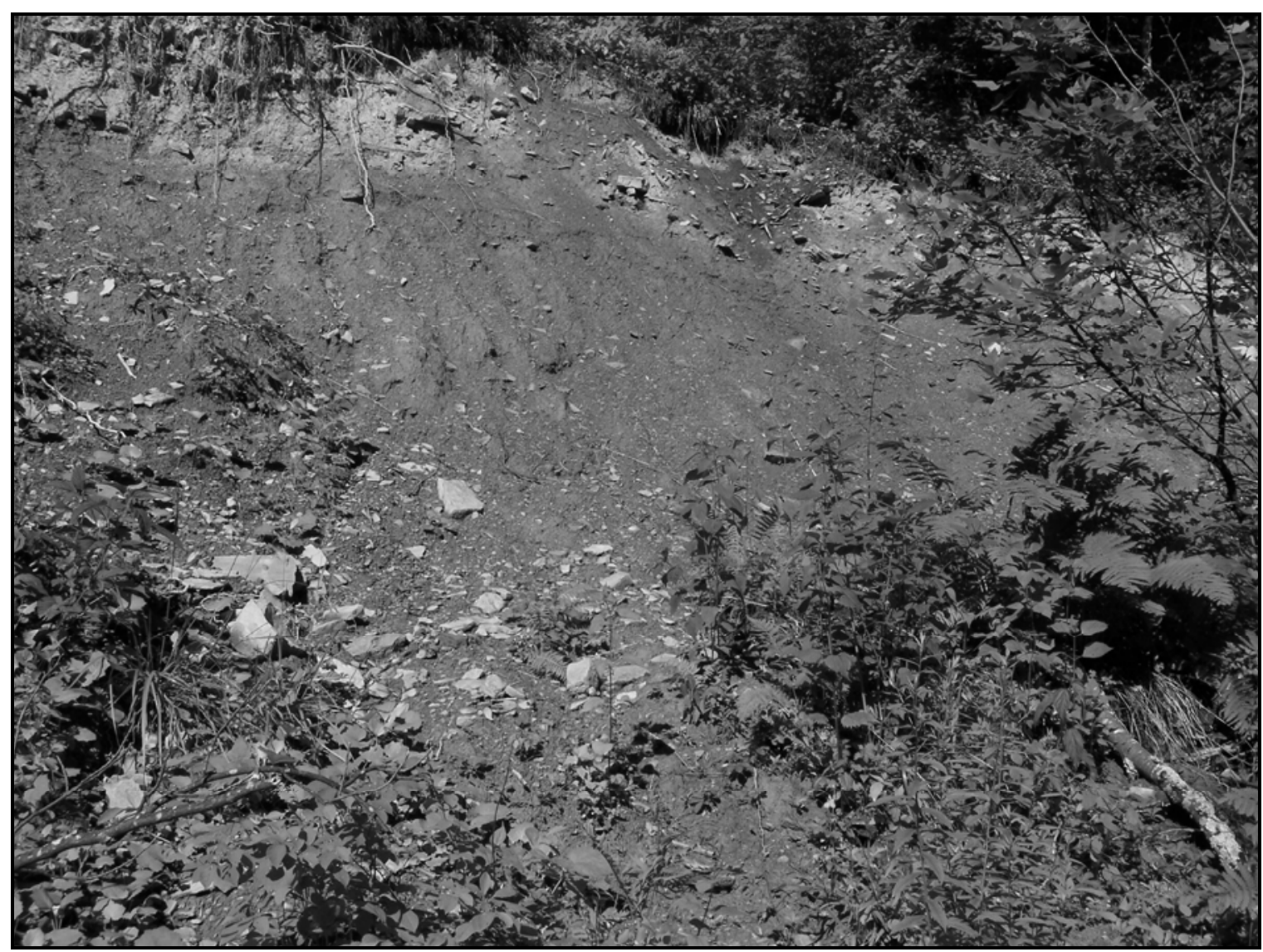

Figure G.10. Hill-side soil slip. 


\section{Appendix H: Sediment Control Structures}

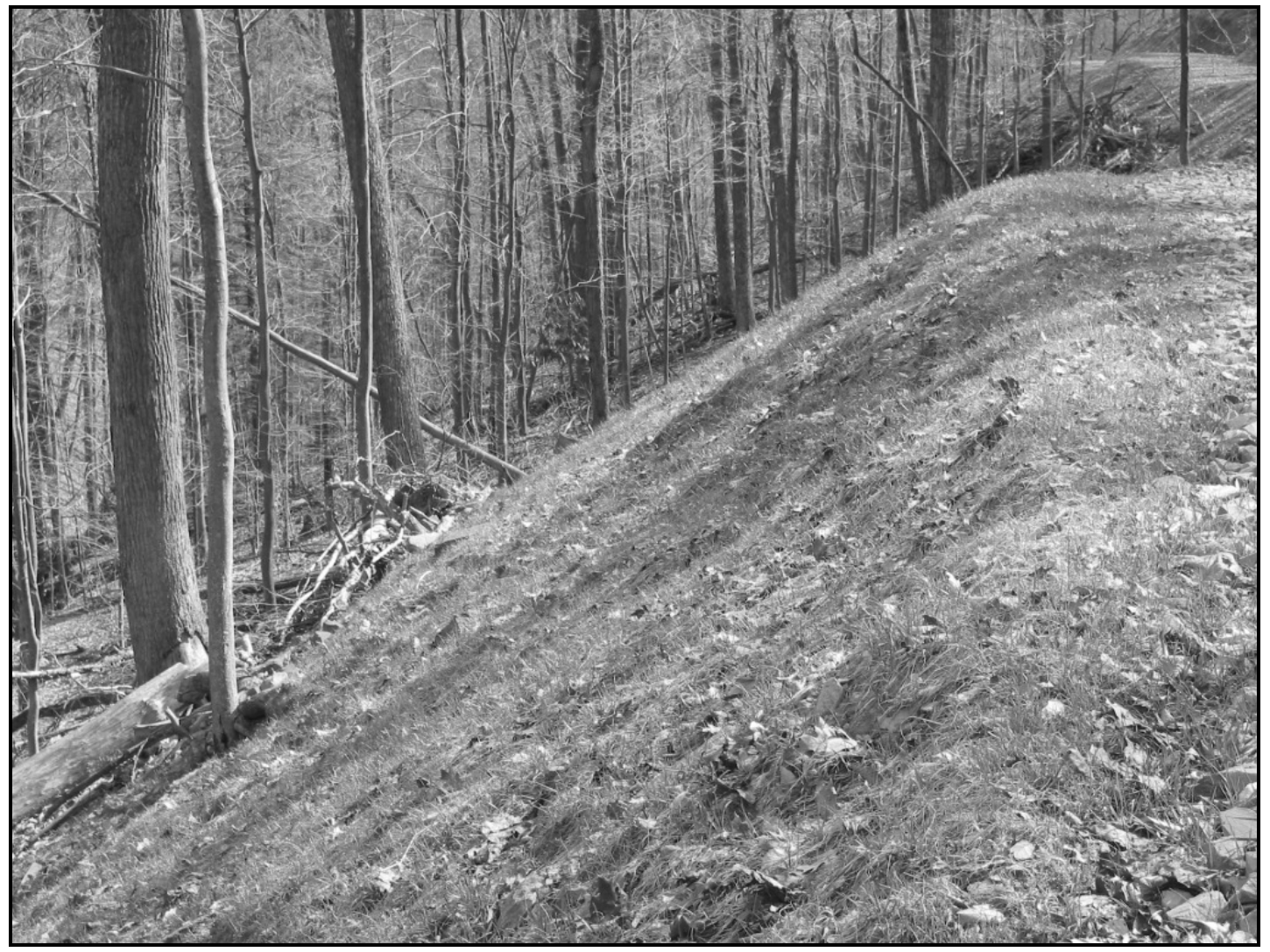

Figure H.1. Properly seeded fill-slopes allow the soil underneath to stabilize and impede gravity and water from dislodging and transporting soil particles during common precipitation events. 


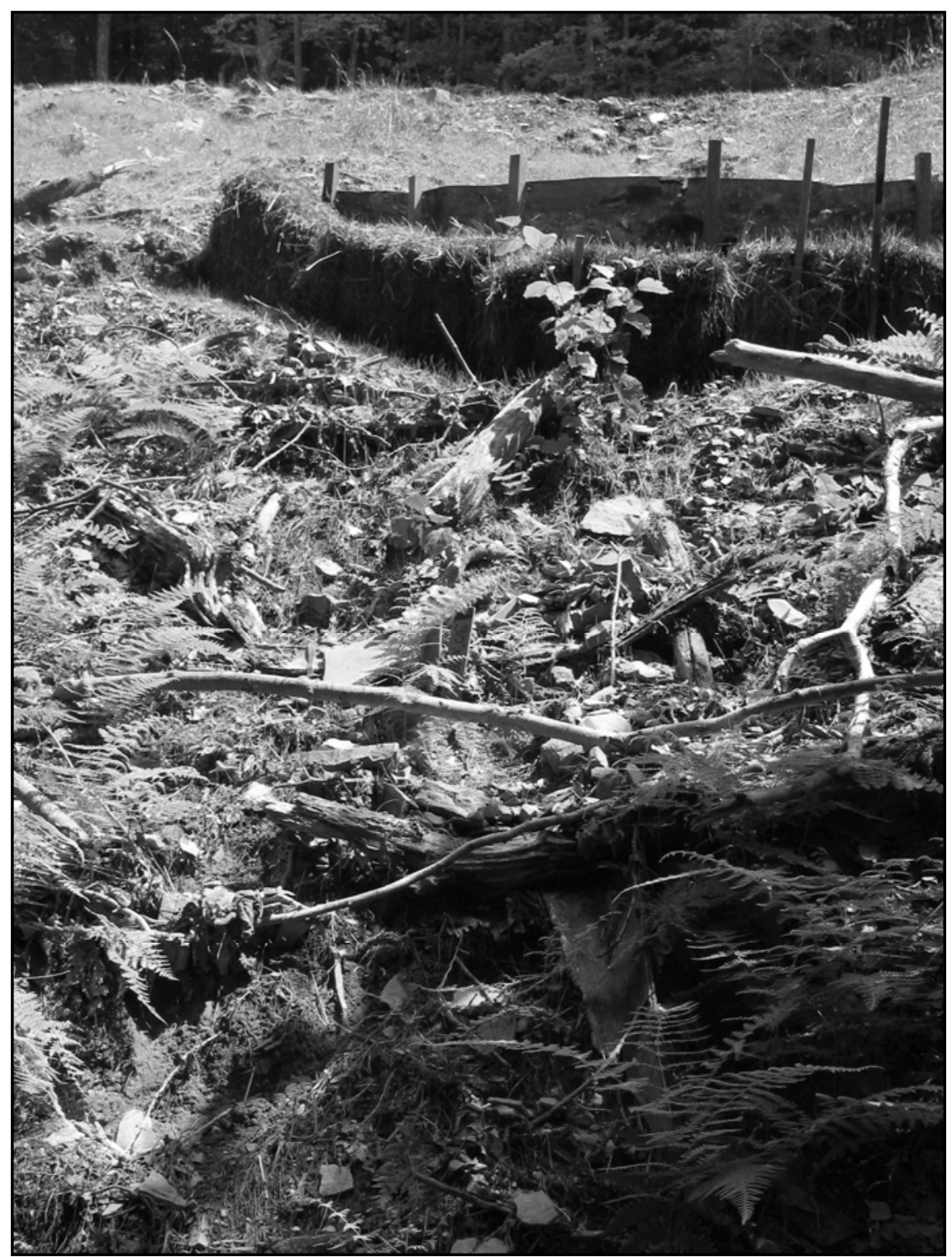

Figure H.2. Hay bales and silt-fence installed below culvert to capture sediment material while still allowing the water to flow through that area. 


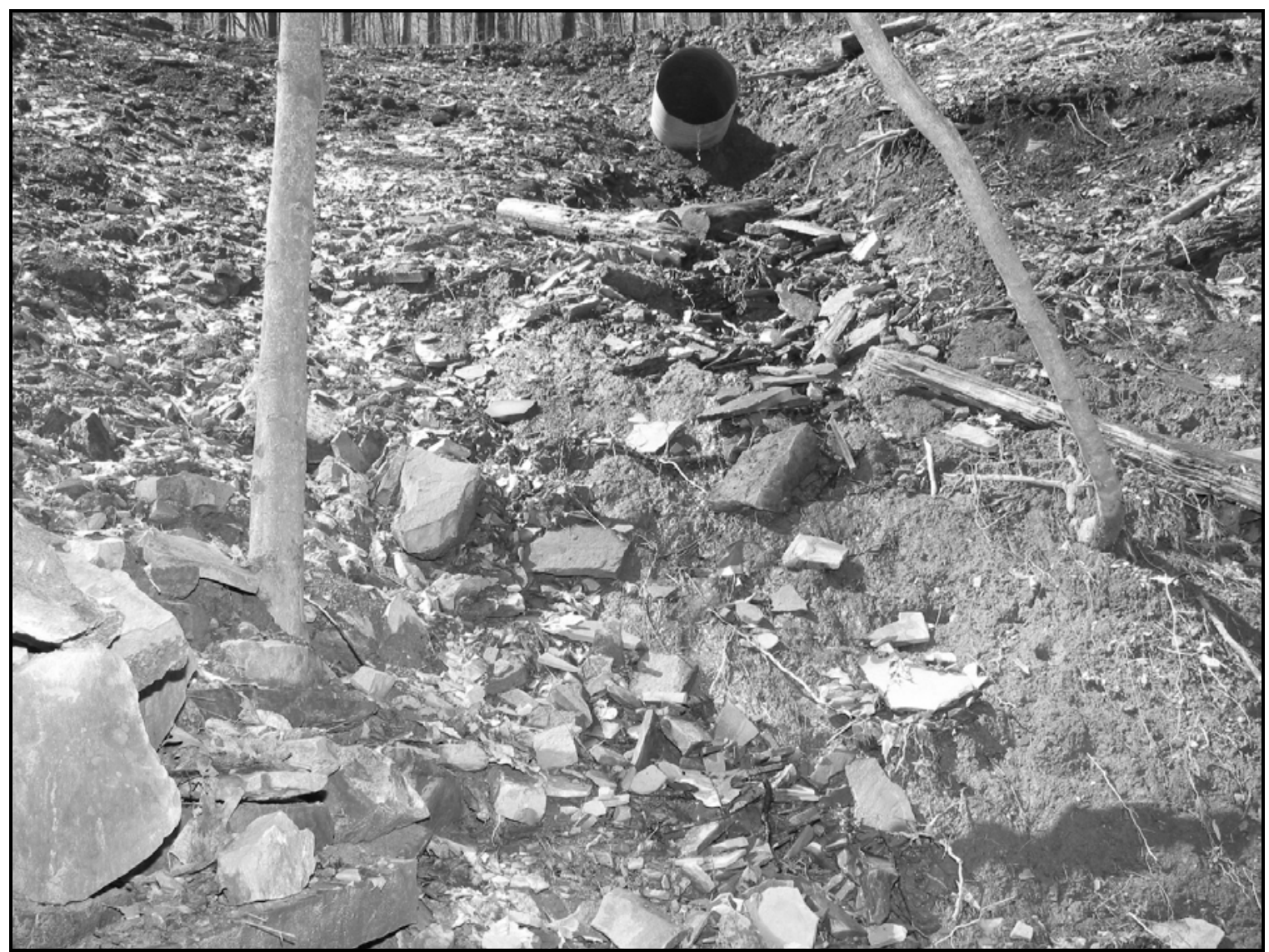

Figure H.3. Rip-rap installed underneath culvert outlet to reduce the force of falling water. 


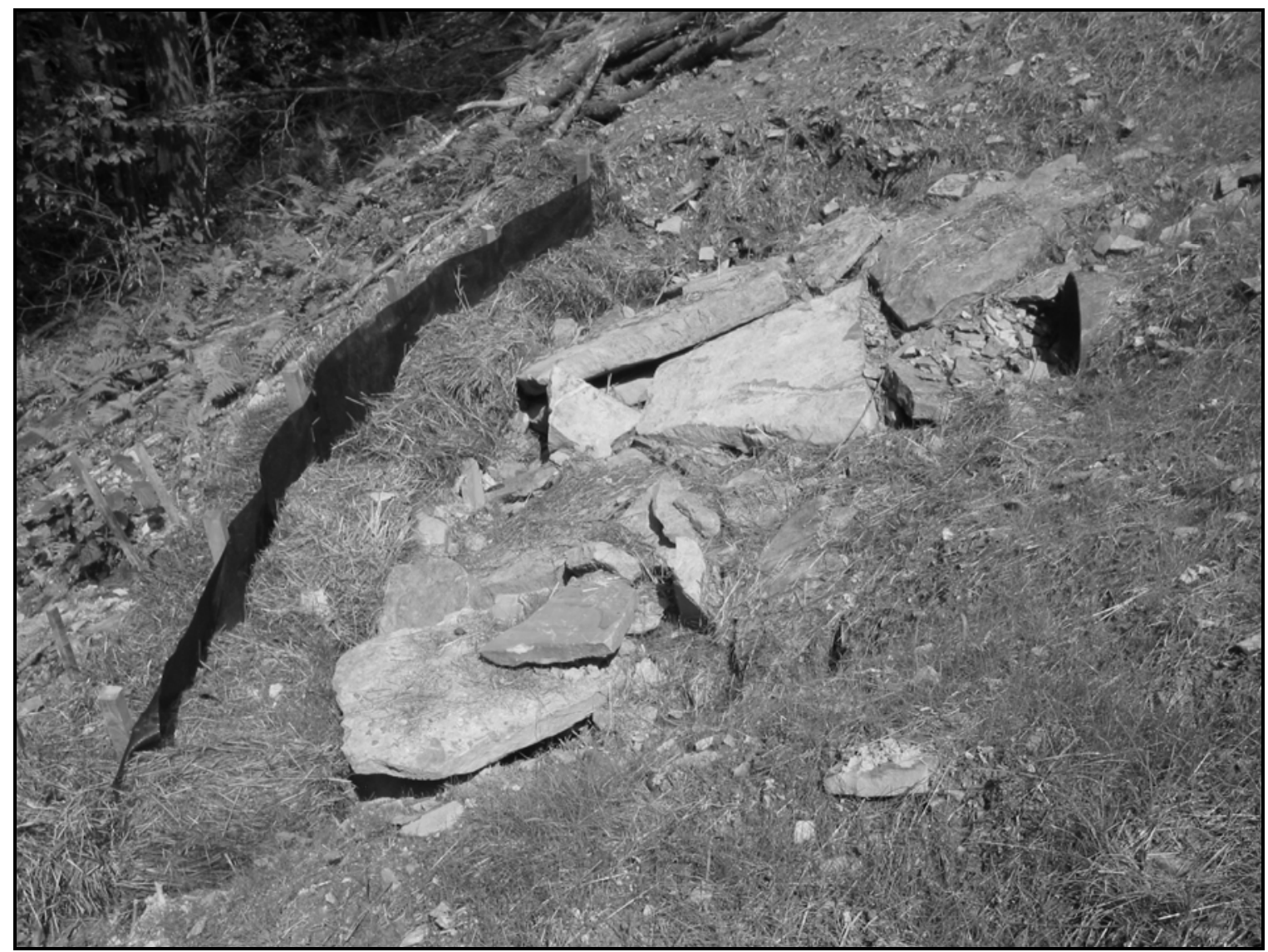

Figure H.4. Rip-rap installed beneath culvert outflow to dissipate the force of falling water. 


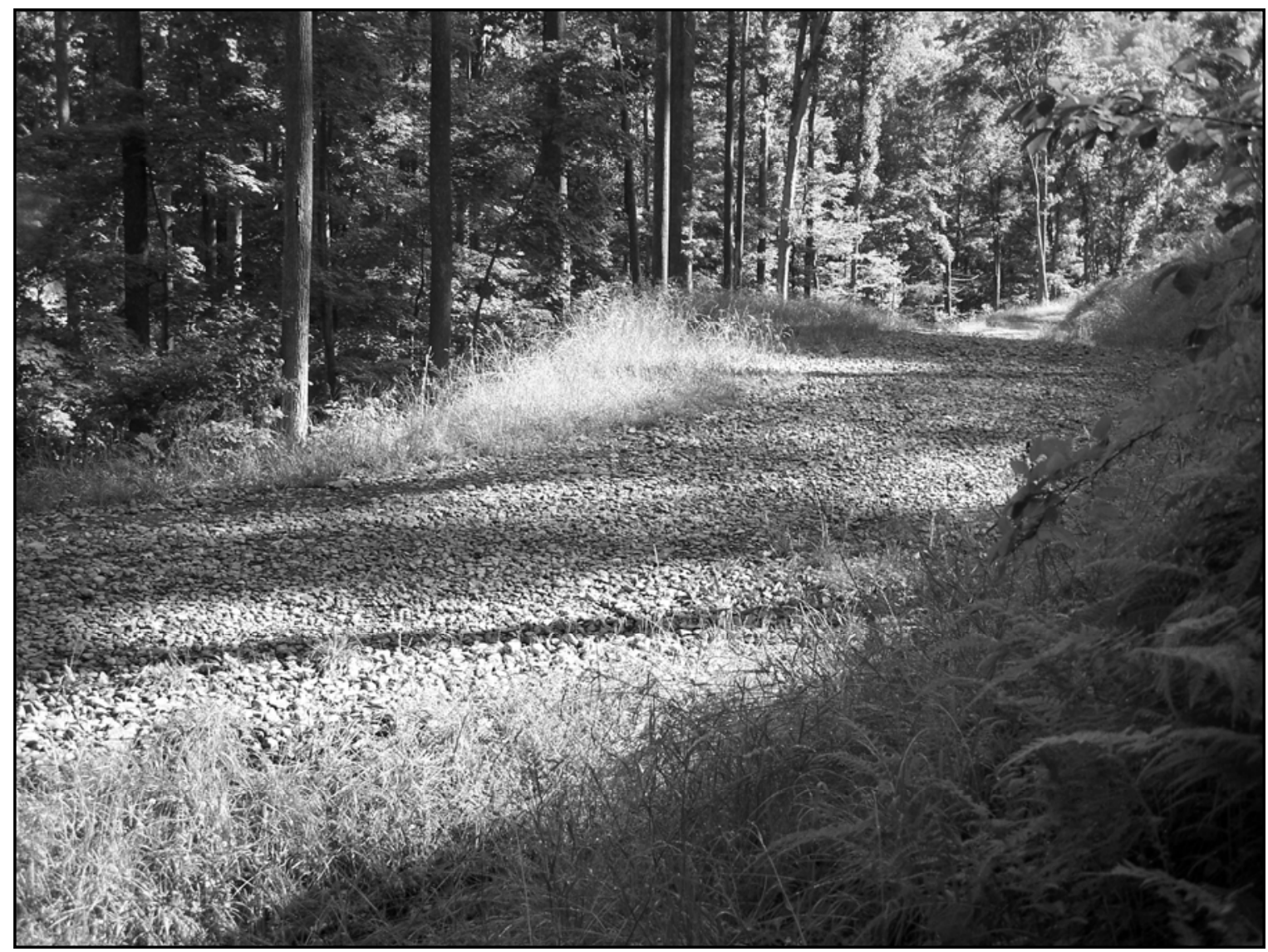

Figure H.5. Haul Road graveled and embankments completely vegetated to aid in stabilization. 


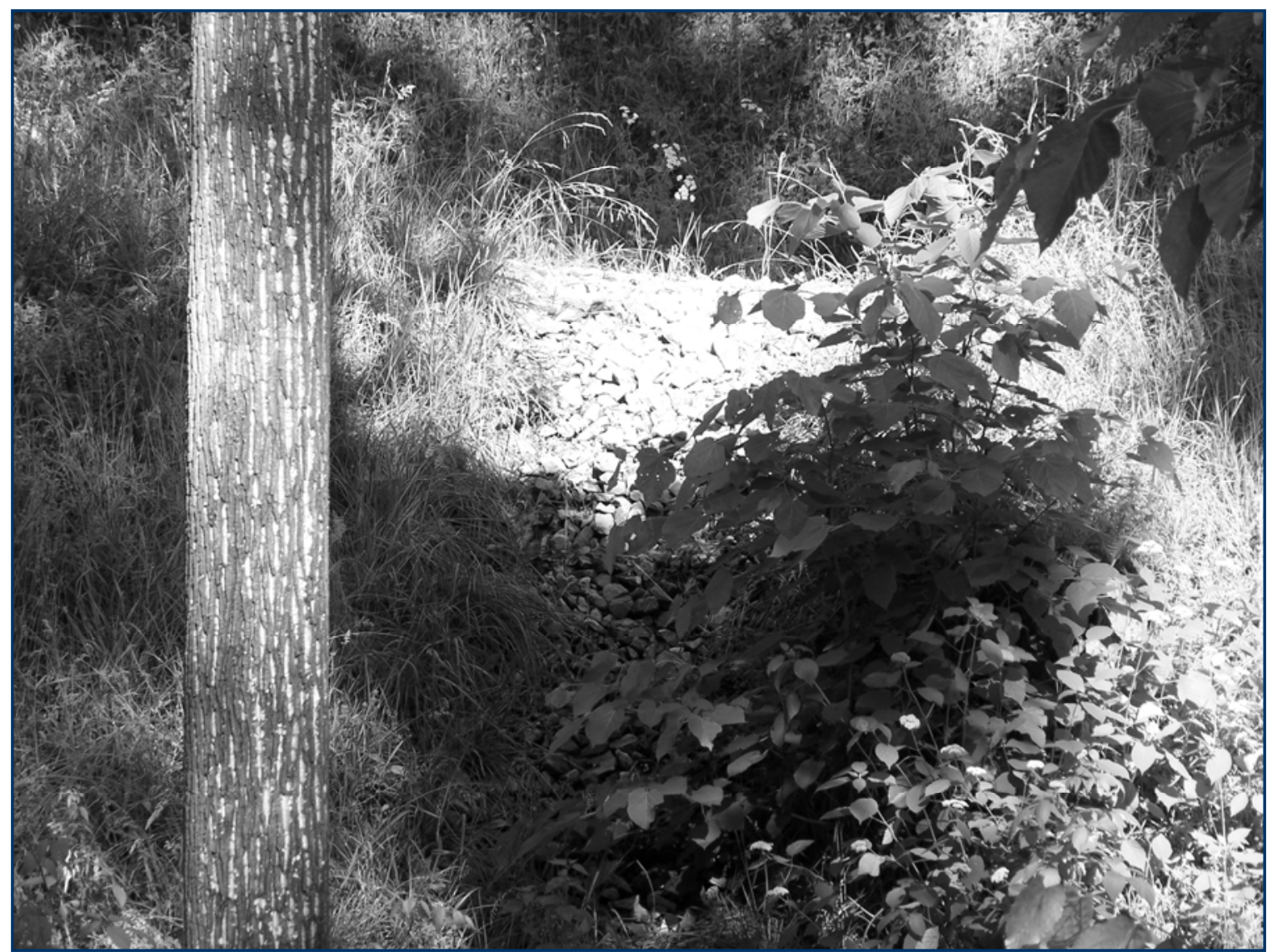

Figure H.6. Broad based dip outlet riprapped to prevent channeling of the fill-slope using limestone rocks to prevent erosion. 


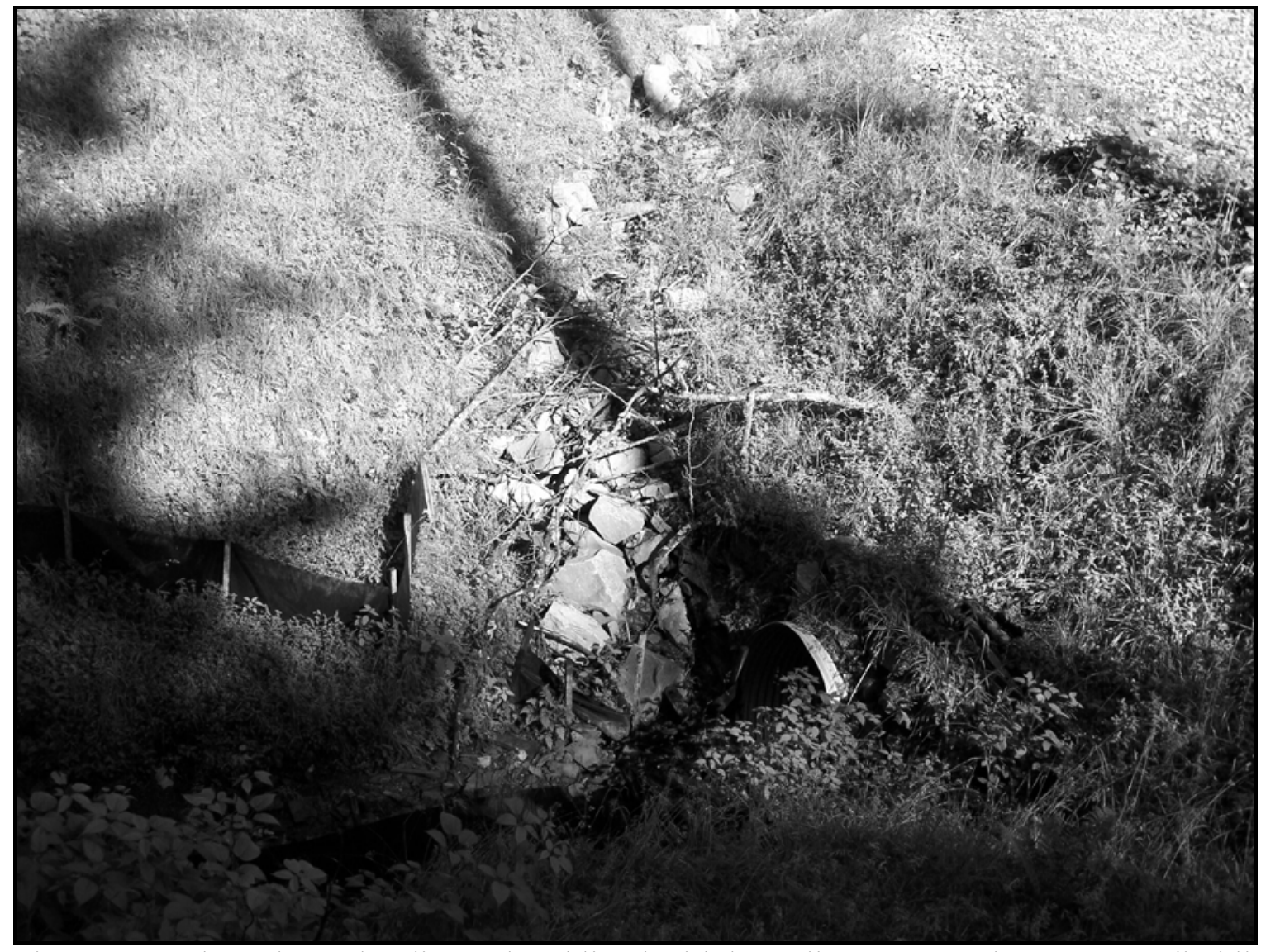

Figure H.7. Flow channel redirected and lined with large limestone rock to prevent ditchline and cutslope erosion. 